\title{
Światopoglądowy i ideologiczny wymiar epistemicznych układów odniesienia a teistyczno-naturalistyczny epistemiczny układ odniesienia
}

\section{Uwagi wstępne}

U podstaw sporu między „standardowym modelem ewolucyjnym” ${ }^{1}$ (czyli gradualistycznym ewolucjonizmem) a naukowym kreacjonizmem i teorią inteligentnego projektu (ID) tkwi konflikt między odmiennymi epistemicznymi układami odniesienia (EUO): naturalistycznym, nadnaturalistycznym i artyficjalistycznym. Jest to konflikt między odmiennymi wizjami uprawiania nauki, ogniskujący się głównie na tym, jakiego rodzaju wyjaśnienia (naturalistyczne, nadnaturalistyczne, artyficjalistyczne) są w nauce dopuszczalne. ${ }^{2}$ Efektem tego konfliktu są wzajemne oskarżenia o nienaukowość. Jednym z dwóch zasadni-

Dr hab. Krzysztof J. KiLIAN, PRof. UZ - Uniwersytet Zielonogórski, e-mail: kiliankrzysztof @yahoo.pl.

(C) Copyright by Krzysztof J. Kilian \& Filozoficzne Aspekty Genezy.

${ }^{1}$ Por. Thomas NAgel, „Public Education and Intelligent Design”, Philosophy \& Public Affairs 2008, vol. 36, no. 2, s. 193 [187-205].

${ }^{2}$ Wprowadzenie do tej dyskusji odnaleźć można w następujących moich tekstach: „Geneza idei epistemicznych układów odniesienia i ich odmiany”, Filozoficzne Aspekty Genezy 2017, t. 14, s. 137-190, https://tiny.pl/gzx34 (23.12.2018); „Czym są epistemiczne układy odniesienia?”, Filozoficzne Aspekty Genezy 2017, t. 14, s. 191-236, https://tiny.pl/g8xqp (23.12.2018). 
czych źródeł tych oskarżeń jest, jak zauważono, ${ }^{3}$ niewspółmierność teorii bazujących na odmiennych EUO. ${ }^{4}$ Drugim takim źródłem są światopoglądowe i ideologiczne komponenty obecne w EUO. Wokół tej drugiej kwestii skupiać się będą rozważania niniejszego artykułu. ${ }^{5}$

Najogólniej rzecz biorąc, EUO to najbardziej elementarne założenia dotyczące tego, jak należy uprawiać naukę i jak tego robić nie należy. Są to niewielkie, dwu- lub trzyelementowe zbiory najogólniejszych, historycznie zmiennych założeń określających konieczne warunki uprawiania nauki. Koncepcja EUO jest ważnym głosem w sporze o racjonalność nauki. Pokazuje bowiem, że spór ten toczy się na znacznie bardziej podstawowym poziomie niż sugerowały to wszystkie wcześniejsze ujęcia tego problemu. Te wcześniejsze ujęcia skupiały się na dość licznych zbiorach reguł uprawiania nauki. ${ }^{6}$ Zaś charakteryzowane tu

\footnotetext{
${ }^{3}$ Por. np. Kazimierz JoDkowski, „Metafizyczne opowieści nauki jako fundament pluralizmu naukowego", w: Phillip E. Johnson, Wielka metafizyczna opowieść nauki (z posłowiem Kazimierza Jodkowskiego), przeł. Piotr Bylica, Archiwum Na Poczatku ..., z. 13, Polskie Towarzystwo Kreacjonistyczne, Warszawa 2003, s. 75-77 [74-85], https://tiny.pl/q3m5p (29.12.2018); Kazimierz JoDKowski, „Twarde jądro ewolucjonizmu”, Roczniki Filozoficzne 2003, t. 51, z. 3, s. 77 [77-117], https://tiny.pl/q3m5j (29.12.2018); Kazimierz JodKowsKI, „O twardym jądrze ewolucjonizmu”, Problemy Genezy 2015, t. 23, s. 150-151 [131-192]; Kazimierz JodKowski, „Epistemiczny układ odniesienia teorii inteligentnego projektu”, Filozofia Nauki 2006, nr 1 (53), s. 95 [95-105], https://tiny.pl/q3m5n (29.12.2018); Dariusz SAGAN, „Wnioskowanie o projekcie a warunek niezależnej wiedzy o projektancie", Przegląd Filozoficzny - Nowa Seria 2014, nr 2 (90), s. 166 [153171], https://tiny.pl/tq9r4 (29.12.2018).

${ }^{4}$ Zagadnienie to przedstawiłem w następujących artykułach: „Epistemiczne układy odniesienia a problem interteoretycznej niewspółmierności - część 1", Filozoficzne Aspekty Genezy 2017, t. 14, s. 237-280, https://tiny.pl/gzx3s (28.12.2018); „Epistemiczne układy odniesienia a problem interteoretycznej niewspółmierności - część 2", Filozoficzne Aspekty Genezy 2017, t. 14, s. 281-325, https://tiny.pl/gzx3v (28.12.2018).

${ }^{5}$ Artykuł ten obszernie korzysta z dorobku Zielonogórskiej Grupy Lokalnej „Nauka a Religia”. Mam tu na myśli Serwis Filozoficzny „Nauka a Religia”, czasopismo internetowe Filozoficzne Aspekty Genezy, serię książkową Biblioteka Filozoficznych Aspektów Genezy oraz liczne prace członków ZGL publikowane w innych czasopismach i seriach książkowych.

${ }^{6}$ Podam w tym miejscu tylko jeden przykład świadczący o liczności analizowanych reguł w ramach wspominanych tu ujęć. Paul Feyerabend, gdy uznawał się za krytycznego racjonalistę, bronił około dziesięciu reguł skutecznego uprawiania nauki. Później, już jako anarchista, wystę pował przeciwko też około dziesięciu, wyraźnie wyartykułowanym, ponadhistorycznym regułom. Te reguły to: zasada falsyfikacji; zasada rewizji; zasada empiryzmu; zasada sprawdzalności; zasada realizmu; zasada proliferacji; zasada stronniczości; zasada tolerancji; zasada uporczywości (por. np. Kazimierz Jodкоwsкı, „Filozofia nauki Paula K. Feyerabenda. Stadium umiarkowane”, Studia Filozoficzne 1979, nr 11 (168), s. 74 [59-75]; Kazimierz JodкоwsкI, „Od krytycznego ra-
} 
ujęcie wskazuje, że za pomocą dwóch lub trzech warunków wstępnie rozstrzyga się, co jest nauką, a co nią nie jest. ${ }^{7}$ Nieprzestrzeganie tych warunków wystarczało i wystarcza nadal do uznania jakiejś propozycji teoretycznej za nienaukową. Dlatego też jest koncepcją trafnie opisującą mechanizmy uznawania poglądów i teorii za naukowe lub nienaukowe. Koncepcja ta odnosi się również do istotnego dla kultury Zachodu konfliktu między nauką a religią i odsłania jego podłoże. Na to właśnie zagadnienie położony zostanie nacisk w niniejszym artykule.

Nie licząc niniejszych uwag, artykuł ten składa się z trzech paragrafów. Paragraf drugi („Światopoglądowy i ideologiczny wymiar EUO”) wyjaśnia, na czym polega światopoglądowe i ideologiczne zaangażowanie EUO, oraz wskazuje na światopoglądowe i ideologiczne składniki omawianych kategorii. Pokazane tam też zostanie, że efektem ideologiczno-światopoglądowego konfliktu między odmiennymi EUO jest, zachodząca już, zmiana oblicza zachodniej cywilizacji.

Na tym tle, w paragrafie trzecim („Teistyczno-naturalistyczny EUO i jego problemy") przedstawiony zostanie teizm naturalistyczny. Najpierw wskażę, że uprzednio omówione EUO tworzą poznawcze ramy dla uprawiania nauki. Zaś naturalistyczny teizm jest takim EUO, który tworzy również inną, specyficzną, światopoglądową ramę uprawiania nauki. Dzięki niej ma być możliwe zażegnanie kryzysu wiary wśród ludzi wykształconych, w szczególności naukowców. Kryzys ten jest następstwem niezgodności tradycyjnego teistycznego oraz współczesnego naukowego opisu świata.

cjonalizmu do anarchizmu metodologicznego”, w: Andrzej L. ZACHARIASZ (red.), Profile racjonalności, Wydawnictwo UMCS, Lublin 1988, s. 141-142 [135-158]; Kazimierz JoDKowsкI, „Nauka w oczach Feyerabenda", w: Kazimierz JoDKOwSKI (red.), Czy sprzeczność może być racjonalna?, Realizm. Racjonalność. Relatywizm, t. 4, Wydawnictwo UMCS, Lublin 1986, s. 248 [227-270]; John Preston, Feyerabend: Philosophy, Science and Society, Polity Press, Cambridge UK, Blackwell, Malden, Massachusetts 1997, s. 137-138; Krzysztof J. KiLIan, Poglądy filozoficzne Paula K. Feyerabenda. Część I. Program metodologiczny, Oficyna Wydawnicza Uniwersytetu Zielonogórskiego, Zielona Góra 2014, s. 77-78; Krzysztof J. Kilıan, „Wzrost wiedzy a zasada tolerancji”, w: Jakub Michalczenia, Jadwiga MizińsKa i Katarzyna Ossowska (red.), Poszukiwania filozoficzne. Tom I: Nauka, Prawda. Panu Profesorowi Józefowi Dębowskiemu w darze, Instytut Filozofii Uniwersytetu Warmińsko-Mazurskiego w Olsztynie, Olsztyn 2014, s. 155-156 [155173], https://tiny.pl/xhzfq [22.12.2018]).

${ }^{7}$ Por. Kilian, „Czym są epistemiczne...”, s. 192-213. 
Uwagi te pozwolą na sformułowanie definicji tej odmiany EUO, jaką jest teizm naturalistyczny, i jej twardego jądra (zbioru takich metafizycznych tez, z których zwolennicy tego teizmu nigdy nie zrezygnują, gdyż ich porzucenie jest tożsame z odrzuceniem podstawowych założeń, na których opiera się ta odmiana EUO).

Następnie przebadane zostanie inne zadanie stawiane przed teistyczno-naturalistycznym EUO. Ma on być, w zamierzeniu jego zwolenników, udaną próbą obrony cywilizacji chrześcijańskiej przed próbami przekształcenia jej w cywilizację postchrześcijańską. Obrona ta odbywać ma się drogą pogodzenia obrazu świata współczesnego przyrodoznawstwa z teizmem chrześcijańskim.

W ostatniej części tego paragrafu pokazane zostanie, że zarówno zażegnanie kryzysu wiary, jak i godzenie obrazu świata współczesnego przyrodoznawstwa z teistycznym obrazem świata odbywa się drogą „umiejętnego czytania” ksiąg Pisma Świętego. Zaś takie czytanie ma olbrzymie koszty światopoglądowe i epistemiczne.

Wyniki przeprowadzonych w niniejszym artykule rozważań podsumowane zostaną w paragrafie ostatnim.

\section{2. Światopoglądowy i ideologiczny wymiar EUO}

Celem każdego światopoglądu jest usensownienie życia ludzkiego. Innymi słowy, niektórym ludzkim działaniom światopogląd nadaje sens, innym zaś tego sensu odmawia. Treść światopoglądu na ogół determinowana jest przez jedną z podstawowych dziedzin kultury: naukę, religię czy sztukę. ${ }^{8}$ Rozpowszechnienie się takich, nazywanych światopoglądami, zespołów przekonań, opinii i postaw dotyczących ludzkiej egzystencji, jak zauważono, pozostaje w silnym związku z krytyką religijnych uzasadnień sensu życia:

autonomizacja światopoglądu jako formy aktywności kulturowej i egzystencjalnej człowieka w znacznej części jest konsekwencją umacniania się przekonania o niezasadności religii. Wraz z podważaniem religii jako dziedziny uzasadniającej sens egzy-

\footnotetext{
${ }^{8}$ Por. np. Andrzej L. ZaCharIasz, Filozofia. Jej istota i funkcje, Wydawnictwo UMCS, Lublin 1994, s. 180-183.
} 
stencji ludzkiej jej funkcje przejmował światopogląd. ${ }^{9}$

Szczególną rolę odgrywa tu nauka, gdyż

zaczęła [ona] śmiało odpowiadać na pytania, które jeszcze nie tak dawno były zarezerwowane tylko dla filozofii i religii: jak powstał wszechświat, w jaki sposób pojawiło się życie na Ziemi, czy natura stworzyła człowieka. ${ }^{10}$

$\mathrm{Na}$ wspomniane pytania nauka zaczęła odpowiadać w bardzo konkretny sposób, określając to, co jest sensowne, i to, co sensu jest pozbawione:

nauka, z której wykluczono Boga, stopniowo umniejsza rolę człowieka w świecie. Ze swego biblijnego miejsca jako wicekróla świata rządzonego przez Boga człowiek upadł, uzyskując teraz status równy lub nawet niżzzy, porównywalny z reszta ,,przyrody" lub nawet $z$ wytwarzanymi przez niego samego wyrafinowanymi maszynami, takimi jak komputery. ${ }^{11}$

W klasycznym, Diltheyowskim rozumieniu tej nazwy, Weltanschauungen odpowiadać miały na dwie zagadki: życia i świata. ${ }^{12}$ Twarde jądra dotychczas przebadanych EUO zakładają określone odpowiedzi na te zagadki:

Kontrowersja ewolucjonizm-kreacjonizm jest $\mathrm{w}$ tej perspektywie starciem dwu różnych sposobów widzenia świata i miejsca człowieka w tym świecie, ${ }^{13}$

\footnotetext{
${ }^{9}$ Andrzej L. Zachariasz, Poznanie teoretyczne. Jego konstytucja i status, Wydawnictwo UMCS, Lublin 1989, s. 38.

${ }^{10}$ Wypowiedź Jerzego Lukierskiego przytaczam za: Anna WoJnar, „Czy nauka zastąpi religię?", Alma Mater. Miesięcznik Uniwersytetu Jagiellońskiego 2008, nr 108, s. 92 [91-94], https:// tiny.pl/g26sl (22.12.2018).

${ }^{11}$ CSSHS Editorial Staff, „Lesson 7. Mans's Creativity: Science”, w: CSSHS Editorial Staff, A Creation Course - In 13 Lessons, Creation Social Science and Humanities Society. Quarterly Journal 1990, vol. 12. no. 1, s. 33-38, wersja elektroniczna bez numerów stron: https://tiny.pl/th $34 \mathrm{w}(12.12 .2018)$.

${ }^{12}$ Por. Wilhelm Dilthey, „O istocie filozofii”, w: Wilhelm Dilthey, $\mathbf{O}$ istocie filozofii i inne pisma, przeł. Elżbieta Paczkowska-Łagowska, Biblioteka Klasyków Filozofii, PWN, Warszawa 1987, s. 4 [3-112].

${ }^{13}$ Kazimierz JodKошsкі, Metodologiczne aspekty kontrowersji ewolucjonizm-kreacjonizm, Realizm. Racjonalność. Relatywizm, t. 35, Wydawnictwo UMCS, Lublin 1998, s. 201. Por. też Kazimierz JoDKOwski, „Darwinowska teoria ewolucji jako teoria filozoficzna”, w: Stefan KonstańCZAK i Tomasz TurowsKi (red.), Filozofia jako mądrość bycia, Oficyna Wydawnicza Uniwersyte-
} 
nieantropocentrycznego i antropocentrycznego układu odniesienia; ${ }^{14}$ „konfliktem między dwoma rywalizującymi zaangażowaniami filozoficznymi”. ${ }^{15}$

Kreacjonizm jest nadnaturalistycznym interwencjonizmem, „opcją teistyczną", ${ }^{16} \mathrm{w}$ myśl której Bóg raz na jakiś czas interweniuje w świat przyrody, zaś jego interwencje mogą, ale nie muszą, łamać istniejące prawa przyrody: ${ }^{17}$

teista nie jest $[\ldots]$ zobowiązany do opowiedzenia się za jakimkolwiek konkretnym

tu Zielonogórskiego, Zielona Góra 2009, s. 17-18, 21 [17-23], https://tiny.pl/q3m56 (21.12.2018); Kazimierz JodKowski, „Dlaczego ewolucjonizm prowadzi do ateizmu?”, w: Józef Dє̨вowsкı i Marek Hetmański (red.), Poznanie. Czlowiek. Wartości. Prace ofiarowane Profesorowi Zdzisławowi Cackowskiemu, Wydawnictwo UMCS, Lublin 2000, s. 65 [65-76], https://tiny.pl/tq92w (18. 12.2018); Józef Zon, „Nic nowego w starym sporze”, Filozoficzne Aspekty Genezy 2005/2006, t. 2/3, s. 25-27 [25-33], https://tiny.pl/xhkgf (21.12.2018); Richard Dawkins, Rzeka genów. Darwinowski obraz życia, przeł. Marek Jannasz, Oficyna Wydawnicza MOST, Warszawa 1995, s. 58; Alvin Plantinga, „Naturalizm metodologiczny?”, przeł. Radosław Plato, Filozoficzne Aspekty Genezy 2014, t. 11, s. 38 [37-93], https://tiny.pl/xh89b (21.12.2018); wypowiedź Stephena C. Meyera w: Michał Chaberek, „Wykrywanie informacji w komórce. Rozmowa ze Stephenem C. Meyerem”, Fronda 2012, nr 63, s. 108-109 [105-110]; Nancy Pearcey, „Wpływ ewolucjonizmu na filozofię i etykę", przeł. Kazimierz Jodkowski, w: JoDKowsкi, Metodologiczne aspekty..., s. 447 [447-459], https://tiny.pl/gt5w6 (22.12.2018); Keith B. Miller, „The Misguided Attack on Methodological Naturalism”, w: Jill S. Schneiderman and Warren D. Allmon (eds.), For the Rock Record: Geologists on Intelligent Design, University of California Press, Berkeley, Los Angeles, London 2009, s. 121 [117-140].

${ }^{14}$ Nazwę „,antropocentryczny układ odniesienia” (a dokładniej „tradycyjny, teleologiczny i antropocentryczny układ odniesienia") zaczerpnąłem od Michaela J. Dentona (por. Michael J. Denton, „Miejsce życia i człowieka w przyrodzie. Obrona tezy antropocentrycznej”, przeł. Dariusz Sagan, Filozoficzne Aspekty Genezy 2015, t. 12, s. 209 [209-254], https://tiny.pl/gfjgx [14. 12.2018]). Najogólniej rzecz biorąc, wyraża ona przekonanie, zgodnie z którym człowiek zajmuje wyróżnione miejsce w świecie przyrody. Por. też Krzysztof Łastowski, „Kilka uwag o sporze ewolucjonizmu z «naukowym kreacjonizmem» w związku z książką K. Jodkowskiego Metodologiczne aspekty kontrowersji ewolucjonizm-kreacjonizm", Przeglad Filozoficzny - Nowa Seria 2001, nr 1 (37), s. 231 [229-240], https://tiny.pl/tq92v (21.12.2018).

${ }^{15}$ Nancy PeArceY, „Ewolucjonizm po Darwinie”, przeł. Kazimierz Jodkowski, w: JodKowski, Metodologiczne aspekty..., s. 445 [431-446], https://tiny.pl/tq92z (21.12.2018). Por. też Erkki V.R. KoJonen, „Methodological Naturalism and the Truth Seeking Objection”, International Journal for Philosophy of Religion 2016, vol. 79, no. 3, s. 10 przyp. 9 [1-26], https://tiny.pl/gkfxk (12.10.2018).

${ }^{16}$ Por. Kazimierz Jodкоwsкi, „Uczony w ciemnym budynku. Na marginesie metafory Elżbiety Kałuszyńskiej”, w: Józef DĘBowsKi i Ewa StarzyŃSKa-KościuszKo (red.), Nauka. Racjonalność. Realizm. Między filozofią przyrody a filozofią nauki i socjologią wiedzy, Instytut Filozofii Uniwersytetu Warmińsko-Mazurskiego w Olsztynie, Olsztyn 2013, s. 64 [55-67], https://tiny.pl/q3m 
sposobem, w jaki Bóg tego [to jest stworzenia] dokonał. ${ }^{18}$

Składnik światopoglądowy tego EUO jest łatwiejszy do wykrycia od naturalistycznego, bowiem odwołania do Pisma Świętego (lub innych świętych ksiąg, na przykład Koranu czy Upaniszad) są w ramach tego EUO powszechne. ${ }^{19}$ Oto jeden z wielu przykładów takich odwołań. Wyjaśnia on, dlaczego możemy racjonalnie poznawać świat:

metoda naukowa opiera się na z góry założonym, poddającym się racjonalnemu badaniu, porządku wszechświata. To uporządkowanie daje się wyjaśnić jedynie dzięki przyjęciu założenia o stworzeniu tego uporządkowania przez Boga Biblii. „Bóg bowiem nie jest Bogiem zamieszania [...]" (1 List do Koryntian 14:33 [BT]). ${ }^{20}$

Drugi z przykładów mówi o następstwach odstąpienia od podążania za literą Pisma Świętego:

Wyrażona w Biblii doktryna stworzenia jest podstawą chrześcijańsko-biblijnego poglądu na świat. [...] Ten biblijny pogląd na świat jest niezgodny z poglądem na świat teistycznych ewolucjonistów. [...] Lekceważenie doktryny biblijnego stworzenia jest rabowaniem Kościołowi fundamentów ewangelizacji i nauczania. [...] Biblia [...] nie dopuszcza „teistycznej ewolucji”. ${ }^{21}$

1x (21.12.2018); Piotr ByLICA, Wspólczesny teizm naturalistyczny z punktu widzenia modelu poziomów analizy. Problem dzialania sfery nadnaturalnej w przyrodzie, Biblioteka Filozoficznych Aspektów Genezy, t. 7, Instytut Filozofii Uniwersytetu Zielonogórskiego, Zielona Góra 2016, s. 27, https://tiny.pl/gkdv1 (21.12.2018).

${ }^{17}$ Por. JodкоwsкI, „Epistemiczny układ...”, s. 97; Kazimierz JodкоwsкI, „Zasadnicza nierozstrzygalność sporu ewolucjonizm-kreacjonizm”, Przegląd Filozoficzny - Nowa Seria 2012, nr 3 (83), s. 218 [201-222], https://tiny.pl/gkfxn (21.12.2018).

${ }^{18}$ Plantinga, „Naturalizm metodologiczny...”, s. 50.

${ }^{19}$ Por. Jodkowski, „Uczony w ciemnym...”, s. 64; JoDKowski, „Darwinowska teoria...”, s. 21; JoDкошsкI, „Zasadnicza nierozstrzygalność...”, s. 220; Kazimierz JodKowski, „Epistemiczne układy odniesienia i «warunek Jodkowskiego»", w: Anna LatawiEc i Grzegorz BugaJAK (red.), Filozoficzne i naukowo-przyrodnicze elementy obrazu świata 7, Wydawnictwo Uniwersytetu Kardynała Stefana Wyszyńskiego, Warszawa 2008, s. 116 [108-123], https://tiny.pl/g28sn (21.12.2018).

${ }^{20}$ CSSHS Editorial Staff, ,Lesson 7...”.

${ }^{21}$ CSSHS Editorial Staff, „Lesson 1. Creation, the Foundation of the Biblical World View”, w: CSSHS Editorial Staff, A Creation Course..., s. 2-7, wersja elektroniczna bez numerów stron: https://tiny.pl/th318 (12.12.2018). 
Cechą kreacjonizmu, szczególnie uwypuklającą ów światopoglądowy komponent, jest to, że wyniki badań naukowych są uzgadniane z odpowiednimi partiami świętych ksiąg. Widoczne jest to $\mathrm{w}$ wielu różnych wypowiedziach kreacjonistów. Pierwsza z przytaczanych wyraźnie kreśli najogólniejszą teoretyczną perspektywę prowadzenia badań: ${ }^{22}$

Obydwa ewolucjonistyczne modele [gradualistyczny i punktualistyczny] stanowczo przeczą Biblii, która naucza, że Bóg stworzył wszystko, co istnieje. ${ }^{23}$

Wypowiedź druga wskazuje, dlaczego kreacjonistyczne ujęcie pochodzenia życia jest trafne:

Istnieje wiele naukowych świadectw przeciwko ewolucjonizmowi. Świadectwa te automatycznie wspierają kreacjonizm, ponieważ ewolucjonizm i kreacjonizm są jedynymi modelami genezy. [...] Zdumiewająca złożoność [organizmów] świadczy na rzecz projektu dokonanego przez wyższą inteligencję. W pełni potwierdza to List do Rzymian (1:20) [BT]: ,Albowiem od stworzenia świata niewidzialne Jego przymioty wiekuista Jego potęga oraz bóstwo - stają się widzialne dla umysłu przez Jego dziela". ${ }^{24}$

Światopoglądowy charakter tego podejścia dyskwalifikuje go w oczach niektórych filozofów nauki i przyrodników, ${ }^{25}$ bowiem, jak utrzymują, nauka po-

\footnotetext{
${ }^{22}$ Por. Jodkowski, „Uczony w ciemnym...”, s. 58, 63; Kazimierz Jodkowski, „Nienaukowy fundament nauki", w: Zbigniew PIETRZAK (red.), Granice nauki, Lectiones \& Acroases Philosophicae 2013, vol. 6, nr 1, s. 104 [59-108], https://tiny.pl/q3mlq (21.12.2018); Bartosz BorczYK, „Dlaczego teoria ewolucji jest ważna”, w: Andrzej Krajna, Leszek RYk i Krystyna SujaK-Lesz (red.), Problemy dydaktyki fizyki, Oficyna Wydawnicza ATUT, Wrocław 2011, s. 103 [89-115], https://tiny.pl/g262s (21.12.2018); Francisco J. Ayala, Ralph J. Cicerone, M.T. ClegGg, G. Brent Dalrymple, Richard E. Dickerson, Stephen J. Gould, Dudley R. Herschbach, Donald Kennedy, Joseph D. McInerney, John A. Moore, Jeremiah P. Ostriker, George Rupp, Eugenie Scott, Barbara Schulz, and Steven M. Stanley, Science and Creationism: A View from the National Academy of Sciences, National Academy Press, Washington, DC. 1999, s. 7, https:/tiny.pl/tq98f (23. 12.2018).

${ }^{23}$ CSSHS Editorial Staff, „Lesson 3. Evolutionism”, w: CSSHS Editorial Staff, A Creation Course..., s. 14-19, wersja elektroniczna bez numerów stron: https://tiny.pl/th315 (23.12.2018).

${ }^{24}$ CSSHS Editorial Staff, „Lesson 3...”.

${ }^{25}$ Por. Wojciech SADY, „Czego Kazimierz Jodkowski nie dostrzega, jeśli o odkrycia naukowe chodzi?”, w: Piotr Bylica, Krzysztof J. Kilian, Robert Piotrowski i Dariusz Sagan (red.), Filozofia — nauka - religia. Księga jubileuszowa dedykowana Profesorowi Kazimierzowi Jodkowskiemu z okazji 40-lecia pracy naukowej, Oficyna Wydawnicza Uniwersytetu Zielonogórskiego,
} 
winna być wolna od wszelkich światopoglądowych wpływów. ${ }^{26}$

Podsumowując tę cześć rozważań, zauważyć należy, że przekonanie o istnieniu nauki wolnej od światopoglądowych wpływów jest błędne:

Zanim zaczniemy szukać przyczyn dla wyjaśnianych zjawisk, musimy zdecydować, gdzie i jak będziemy ich szukać. ${ }^{27}$

Zaś decyzje takie, na co wielokrotnie zwracano uwagę, nie zależą wyłącznie od faktów i logiki. ${ }^{28}$ Te pierwsze kształtowane są przez odmienne tradycje uprawiania nauki, wywierające silny wpływ na uprzedzenia i przekonania uczonych. Niebagatelną rolę odgrywają tu też motywy o charakterze metafizycznym, a nawet estetycznym i wolicjonalnym, pozwalające uczonemu obstawać przy wybranej przez niego drodze badań. ${ }^{29}$

Zielona Góra 2015, s. 62-64 [59-64], https://tiny.pl/g268h (22.12.2018); Edward O. Wilson, O naturze ludzkiej, przeł. Barbara Szacka, Biblioteka Myśli Współczesnej, Państwowy Instytut Wydawniczy, Warszawa 1988, s. 232-233; Tim M. BerRa, Evolution and the Myth of Creationism: A Basic Guide to the Facts in the Evolution Debate, Stanford University Press, Stanford 1990, s. 130

${ }^{26}$ Por. np. Keith B. Miller, „Countering Public Misconceptions about the Nature of Evolutionary Science”, Georgia Journal of Science 2005, vol. 63, no. 3, s. 178 [175-189], https://tiny.pl /tqw12 (21.12.2018).

${ }^{27}$ JoDKowski, „Nienaukowy fundament...”, s. 105.

${ }^{28}$ Por. np. Paul K. Feyerabend, „Problems of Empiricism”, w: Robert G. Colodny (ed.), Beyond the Edge of Certainty: Essays in Contemporary Science and Philosophy, Prentice-Hall, Englewood Cliffs, New Jersey 1965, s. 227 [145-260]; Paul K. Feyerabend, „Krytyka naukowego rozumu", przeł. Edmund Mokrzycki, w: Edmund МокRZYскI (red.), Racjonalność a styl myślenia, Wydawnictwo IFiS PAN, Warszawa 1992, s. 208 przyp. 51 [167-217]; Thomas S. KunN, Struktura rewolucji naukowych, przeł. Helena Ostromęcka, Justyna Nowotniak, Aletheia, Warszawa 2001, s. 26, 29, 35, 55-56, 60; Kazimierz Jodкоwski, „Z jakim relatywizmem bezskutecznie walczy Wojciech Sady? (Głos w dyskusji)", w: Jan PoмOrsкi (red.), Wartość relatywizmu jako postawy poznawczej, Realizm. Racjonalność. Relatywizm, t. 11, Wydawnictwo UMCS, Lublin 1989, s. 123 [123-146]; JodKowski, „Uczony w ciemnym...”, s. 57; Kazimierz JodKowski, „Kreacjonizm młodej Ziemi a koncepcja Big Bangu. Poglądy Johna Hartnetta z konstruktywistycznej i eksternalistycznej perspektywy", Filozoficzne Aspekty Genezy 2015, t. 12, s. 74-76 [37-79], https://tiny.pl/gs8k7 (22.12.2018).

${ }^{29}$ Por. np. Paul K. Feyerabend, „Wyjaśnianie, redukcja i empiryzm”, w: Paul K. Feyerabend, Jak być dobrym empirystą, przeł. Krystyna Zamiara, Państwowe Wydawnictwo Naukowe, Warszawa 1979, s. 84-85[62-151]. 
Gradualistyczny ewolucjonizm to nie tylko teoria, to również jeden z najbardziej wpływowych światopoglądów, którego porzucenie można przyrównać do intelektualnej burzy prowadzącej do zmiany postrzegania miejsca człowieka we Wszechświecie, jaka rozpętała się w trakcie porzucania geocentryzmu. ${ }^{30}$ Zachodzenie tego procesu zostało już dostrzeżone:

Ci z nas, którzy to rozumieją, muszą rozszerzyć nasze zainteresowanie poza nauki przyrodnicze i zrozumieć wpływ, jaki ewolucjonizm wywiera na całą naszą kulturę. ${ }^{31}$

O wyborze tego światopoglądu decydują ,preferencje kulturowe”, a nie świadectwa empiryczne, gdyż ewolucjonizm ten ,jest w większym stopniu wytworem myśli Zachodu niż prawdziwym faktem empirycznym". ${ }^{32}$ I właśnie dlatego

wybór interpretacji procesu ewolucji w kategoriach celu lub przypadku jest uwarunkowany przyjmowanymi założeniami filozoficznymi i nie wynika tylko z biologicznej teorii ewolucji. ${ }^{33}$

Światopogląd ten charakteryzowany jest w kategoriach najbardziej podsta-

\footnotetext{
${ }^{30}$ Por. np. Fred Hoyle and Nalin Chandra Wickramasinghe, Evolution from Space: A Theory of Cosmic Creationism, Simon \& Schuster, Inc., New York 1984, s. 137-138; Grzegorz P. SŁOwIK i Krzysztof J. Kilian, „Hoyle i matematyczne dylematy ewolucjonizmu”, w: ByLICA, KiLIan, PIOTROWSKI i SAGAN (red.), Filozofia — nauka — religia..., s. 401 [395-408], https://tiny.pl/tqw1v (22.12.2018).

${ }^{31}$ Pearcey, „Wpływ ewolucjonizmu...”, s. 447.

${ }^{32}$ Stephen Jay Gould, „Epizodyczny charakter zmian ewolucyjnych”, w: Stephen Jay Gould, Niewczesny pogrzeb Darwina. Wybór esejów, przeł. Nina Kancewicz-Hoffman, Biblioteka Myśli Współczesnej, Państwowy Instytut Wydawniczy, Warszawa 1991, s. 184, 189 [183-200]. Por. też JoDKowski, „Twarde jądro...”, s. 110; Kazimierz JodKowsкi, „Filozofia przyrody a nauki przyrodnicze”, Colloquia Communia 2007, 1-2 (82-83), s. 21 [15-22]; Kazimierz JoDKowski, „Ruch kreacjonistyczny jest elementem pluralizmu naukowego", Przegląd Filozoficzny - Nowa Seria 2001, nr 1 (37), s. 250 [241-253], https://tiny.pl/gdw95 (22.12.2018); Kazimierz JoDKowsкi, „Ewolucja ewolucjonizmu z popperowskiego punktu widzenia”, Filozofia Nauki 2003, nr 2 (42), s. 61 [51-63], https://tiny.pl/tqwj9 (22.12.2018); Dariusz SAGAN, „Problem religijnego charakteru teorii inteligentnego projektu", Studia Philosophica Wratislaviensia 2011, vol. 6, fasc. 4, s. 56 [55-74], https://tiny.pl/q336q (22.12.2018).

${ }^{33}$ Anna Lemańska, „Ewolucja jako realizacja projektu?”, Filozofia i Nauka 2015, t. 3, s. 357 [353-358], https://tiny.pl/tqw4j (22.12.2018).
} 
wowej odmiany mitu, ${ }^{34}$ mitu kosmogonicznego: ${ }^{35}$

II połowa XX wieku to początek okresu przejściowego od dawnej, opartej na chrześcijaństwie i jego systemie wartości, cywilizacji do nowej, postchrześcijańskiej cywilizacji z naukowym, a dokładniej: z ewolucjonistycznym, nowym mitem pochodzenia. ${ }^{36}$

Mit ten waloryzowany jest bardzo pozytywnie:

epos o ewolucji jest prawdopodobnie najlepszym z posiadanych przez nas kiedykolwiek mitów. ${ }^{37}$

Ten „Wielki Mit Ewolucji” ${ }^{88}$ odpowiada na pytania: „dlaczego istniejemy?” oraz ,jaki jest cel naszej ludzkiej egzystencji?” ${ }^{39}$ Odpowiadając z naturalistycznej perspektywy na tak podstawowe kwestie, ,,już nie musimy odwoływać się

\footnotetext{
${ }^{34}$ Nazwa ,mit” rozumiana jest tu w sposób klasyczny:

zawsze jest to opowieść o „stworzeniu”, relacja o tym, jak coś powstało, zaczęło być. Mit mówi tylko o tym, co wydarzyło się faktycznie, o tym, co przejawiło się w sposób wyraźny.

Mircea Eliade, Aspekty mitu, przeł. Piotr Mrówczyński, Wydawnictwo KR, Warszawa

${ }^{35}$ „Mit kosmogoniczny dostarcza wzoru dla wszystkich [innych] mitów” (Mircea EliadE, W poszukiwaniu historii i znaczenia religii, przeł. Agnieszka Grzybek, Wydawnictwo KR, Warszawa 1997, s. 109).

${ }^{36}$ Kazimierz JodKowski, „Nauka a religia”, Filozofia Nauki 2006, nr 1 (53), s. 31 [31-32], https://tiny.pl/g268c (22.12.2018). Por. też JodKowsKi, „Ruch kreacjonistyczny...”, s. 250; wypowiedź Kazimierza Jodkowskiego w: Robert Gromadzki, „Zmierzch cywilizacji Zachodu. Rozmowa z profesorami Kazimierzem Jodkowskim i Wojciechem Sadym, filozofami w Uniwersytecie Zielonogórskim", Gazeta Lubuska 29-30 grudnia 2001, nr 303 (15314), s. 13, https://tiny.pl/tqwj1 (22.12.2018); wypowiedź Michaela Behe'ego w: Mark RyLAND, „«Teoria inteligentnego projektu» podważa teorię ewolucji. Już sama złożoność stworzenia świadczy o działaniu siły wyższej. Darwinizm? Nie ma szans. Wywiad z Michaelem J. Behe'em dla Our Sunday Visitor", przeł. Dariusz Sagan, Na Początku ... 2004, nr 11-12A (187-188), s. 418 [414-420], https://tiny.pl/g2vmb (22.12.

${ }^{37} \mathrm{~W}_{\text {ILSON, }}$ O naturze..., s. 212.

${ }^{38}$ Por. Plantinga, „Naturalizm metodologiczny...”, s. 47.

${ }^{39}$ Por. Jodkowski, „Nauka a religia...”, s. 31; Ewa ZaLewsKa, „Johna F. Haughta poglądy na temat relacji nauka-religia”, Filozoficzne Aspekty Genezy 2007/2008, t. 6/7, s. 130 [127-160], https://tiny.pl/tqwjk (29.12.2018).
} 1998, s. 11. 2018). 
do sił nadprzyrodzonych”. ${ }^{40}$ „Nie ma [zatem] żadnej potrzeby, żeby przywoływać tu Boga, który stworzył wszechświat". ${ }^{41}$ Dlatego też mówi się, że

ewolucjonizm jest najskuteczniejszym narzędziem do produkowania ateizmu, jakie kiedykolwiek wymyślono. ${ }^{42}$

Światopogląd ewolucjonistyczny jest również charakteryzowany przez pryzmat takich kategorii jak ideologia i religia:

[Mit ów] jest rozpowszechniany jako ideologia, jako świecka religia — jako dojrzała alternatywa dla chrześcijaństwa, dająca sens i moralność. ${ }^{43}$

\footnotetext{
${ }^{40}$ Richard Dawkins, Samolubny gen, przeł. Marek Skoneczny, Prószyński i S-ka, Warszawa 1996, s. 17. Warto w tym miejscu odnotować, że Dawkins, chociaż uznawany za jednego z czterech jeźdźców ateizmu (por. np. Alice GribBin, „Preview: The Four Horsemen of New Atheism Reunited", NewStatesman 22 December 2011, https://tiny.pl/tqwph [22.12.2018]; Piotr GutowskI, „Czym jest «nowy ateizm»?”, w: Marek SŁoмkA (red.), Nauki przyrodnicze a nowy ateizm, Filozofia Przyrody i Nauk Przyrodniczych, t. 8, Wydawnictwo KUL, Lublin 2012, s. 7-18 [7-45], https://tiny.pl/tqwpx [28.12.2018]), jest zwolennikiem nauczania obok teorii ewolucji również wyjaśnień nienaturalistycznych:

argument z projektu, ważna część historii religii, nie byłby pominięty w moich [...] [zajęciach poświęconych] edukacji religijnej. Dzieci spoglądałyby na oszałamiające cuda królestw świata ożywionego i poznawałyby darwinizm równolegle $\mathrm{z}$ alternatywami kreacjonistycznymi i same podejmowałyby decyzje.

Richard Dawkins, „Czy nauka jest religią?”, przeł. Ziemowit Ciuraj, Racjonalista 3 grudnia 2012, https://tiny.pl/tqwp9 (22.12.2018).

${ }^{41}$ Wypowiedź Stephena Hawkinga przytaczana za: Tomasz StawiszyŃski, „Bóg jest zbędny”, Newsweek Polska 13 września 2010, https://tiny.pl/g26vx (22.12.2018).

${ }^{42}$ William B. Provine, „Evolution: Free Will and Punishment and Meaning in Life”, Second Annual Darwin Day Celebration, University of Tennessee, Knoxville, Feb. 12, 1998, http://tiny.pl /q6xp8 (28.12.2018), fragment w przekładzie JodKowSKIEGo, „O twardym jądrze...”, s. 162.

${ }^{43}$ Michael Ruse, „How Evolution Became a Religion: Creationists Correct?: Darwinians Wrongly Mix Science with Morality, Politics", National Post 13 May 2000, https://tiny.pl/g4rxp (28.12.2018). Por. też Michael Ruse, „Darwinizm a problem zła”, przeł. Aleksandra Bulaczek, Filozoficzne Aspekty Genezy 2011, t. 8, s. 31-32 [23-38], https://tiny.pl/tqwpz (22.12.2018); JoDKowski, „Dlaczego ewolucjonizm...”, s. 70; JoDKowski, „Twarde jądro...”, s. 110; John Hedley BRooke, „Karol Darwin o religii”, przeł. Dariusz Sagan, Filozoficzne Aspekty Genezy 2011, t. 8, s. 62 [61-74], https://tiny.p1/xhnnn (22.12.2018); Charles TнахтоN, „Nowy argument z projektu”, przeł. Izabela Janus, Filozoficzne Aspekty Genezy 2011, t. 8, s. 163 [155-177], https://tiny.pl/xhn $2 \mathrm{p}(22.12 .2018)$
} 
Ideologia ta zdominowała całą współczesną naukę. ${ }^{44}$ Określana jest ona niekiedy jako fundamentalistyczna ${ }^{45}$ „opcja ateistyczna”, ${ }^{46}$ nowa „filozofia religijna" ${ }^{47}$ „ewangeliczny ateizm" ${ }^{48}$ i ,skomercjalizowany ideologiczny scjentyzm". ${ }^{49}$ Światopoglądowego wsparcia, w opinii niektórych uczonych, dostarcza jej sama nauka:

Mój sposób postępowania jako uczonego jest ateistyczny. Znaczy to, że gdy przeprowadzam eksperyment, zakładam, że żaden bóg, anioł czy diabeł nie wpływa na jego przebieg. Założenie to uzasadnione jest sukcesami, które osiągnąłem w swojej zawodowej karierze. Byłbym zatem osobą intelektualnie nieuczciwą, gdybym nie był ateistą $[\ldots]$ również poza ścianami mojego laboratorium. ${ }^{50}$

\footnotetext{
${ }^{44}$ Por. Kazimierz JoDKowsкi, „Eskapizm teologii i filozofii katolickiej w sprawie «nauka a religia»”, Na Poczatku ... 2005, nr 7-8 (196-197), s. 274 [261-284], https://tiny.pl/gztl8 (23.12. 2018).

${ }^{45}$ Por. Geoffrey Lee Hodge, „Advancing the Atheist Movement: Dawkins, Dennett, and the Second Wave", TheHumanist.com 19 June 2015, https://tiny.pl/g266t (22.12.2018).

${ }^{46}$ Por. Jodкоwski, „Uczony w ciemnym...”, s. 64; Jodкоwsкi, „Darwinowska teoria...”, s. 20; Jodkowski, „Twarde jądro...”, s. 87-88; Jodkowski, „Kreacjonizm młodej Ziemi...”, s. 76-78; Kazimierz Jodkowski, „Poglądy teologiczne Darwina”, w: Damian LeszczyŃski (red.), Ewolucja. Filozofia. Religia, Lectiones \& Acroases Philosophicae 2010, vol. 3, s. 72-73 [59-84], https://tiny.pl /q3m5z (23.12.2018). Por. też Bylica, Wspólczesny teizm..., s. 27; Piotr Bylica and Dariusz SAGAN, „God, Design, and Naturalism: Implications of Methodological Naturalism in Science for Science-Religion Relation”, Pensamiento 2008, vol. 64, núm. 242, s. 624 [621-638], https://tiny. pl/g2884 (23.12.2018); Wojciech SADY, „Dlaczego kreacjonizm «naukowy» nie jest naukowy i dlaczego nie prowadzi do teizmu?”, Przeglad Filozoficzny - Nowa Seria 2001, nr 1 (37), s. 214 [213-228], https://tiny.pl/gdw91 (23.12.2018); Bill JoHnson, „Czy darwinizm ma ateistyczny charakter? Analiza przekonań i czynów Karola Darwina”, przeł. Dariusz Sagan, Filozoficzne Aspekty Genezy 2011, t. 8, s. $76-77$ [75-91], https://tiny.pl/xhnk4 (23.12.2018).

${ }^{47}$ Por. Richard F. Duncan, „Review of Reason in the Balance: The Case against Naturalism in Science, Law and Education, by Philip E. Johnson. Downers Grove, Ill.: InterVarsity Press, 1995", Journal of Law and Religion 2001, vol. 16, no 2, s. 948 [945-949], https://tiny.pl/tqwlj (23.12.2018).

${ }^{48}$ Por. Steve Fuller, „What Has Atheism Ever Done for Science?”, w: Amarnath Amarasingam (ed.), Religion and the New Atheism: A Critical Appraisal, Studies in Critical Social Sciences, vol. 25, Brill, Leiden, Boston 2010, s. 57 [57-78].

${ }^{49}$ Charles L. Harper Jr., Senior Vice President Fundacji Templetona, określił tak popularyzatorską twórczość Richarda Dawkinsa (por. George Johnson, „A Free-for-All on Science and Religion", The New York Times 21 November 2006, https://tiny.pl/thksh [15.12.2018]).

${ }^{50}$ John B.S. Haldane, Fact and Faith, Watts \& Company, London 1934, s. vi-vii (cyt. za: Josh A. Reeves and Steve Donaldson, A Little Book for New Scientists: Why and How to Study
} 
Ideologię tę wspiera również naturalizm metodologiczny, gdyż

jest [on] najbardziej ekonomicznym podejściem [do wyjaśniania] ze znanych — ogranicza się do wyjaśnień, które przyjmują minimalną ilość założeń ontologicznych i, jako taki, prowadzi do przyjęcia ekonomicznego światopoglądu, który jest atrakcyjny dla ludzi nauki. ${ }^{51}$

Również i w tym wypadku krytycy ujęcia naturalistycznego podkreślają, że jego wiarygodność osłabia to, iż ma ono charakter ideologiczny i światopoglądowy. ${ }^{52}$ Pytają też o to, „co w teorii Darwina i jej późniejszym rozwinięciu jest naprawdę naukowego, a które jej elementy są ideologiczne, nienaukowe". ${ }^{53}$ Wskazują także, że to stosunek do teizmu jest jednym z głównych czynników kształtujących światopogląd naturalistyczny:

to przeświadczenie o mocy ich [ewolucjonistów] twierdzeń częściowo zależy od stosunku do teizmu. Jeśli odrzucamy teizm na rzecz naturalizmu, to ta ewolucyjna opowieść staje się jedynym możliwym wyborem. ${ }^{54}$

Science, InterVarsity Press, Downers Grove, Illinois 2016, s. 114).

${ }^{51}$ Ronald G. Larson, „O argumencie z Boga w lukach wiedzy raz jeszcze”, przeł. Joanna Popek, Filozoficzne Aspekty Genezy 2012, t. 9, s. 200 [199-220], https://tiny.pl/xhzg7 (20.12.2018).

${ }^{52}$ Por. np. John AnKerberg i John Weldon, Fakty w sporze: stworzenie czy ewolucja? (z posłowiem Kazimierza Jodkowskiego), przeł. Mieczysław Pajewski, Wydawnictwo MEGAS, Warszawa 2003, s. 40-41. Por. też komentarz do takiego ujęcia: JoDKowsкI, „Metafizyczne opowieści...”, s. 80-81; JodKowsKI, „Filozofia przyrody...”, s. 21; JodKowskI, „Nauka a religia...”, s. 32.

${ }^{53}$ Wypowiedź salwatoriana, ojca Stephena Horna przytoczona za: Dariusz SAGAN, „Debata Benedykta XVI i jego uczniów nad stworzeniem i ewolucją”, Filozoficzne Aspekty Genezy 2005/ 2006, t. 2/3, s. 14 [7-17], https://tiny.pl/xhnqr (23.12.2018). Por. też Mirosław TwardowsKI, „Wiara w stworzenie a teoria ewolucji: konflikt czy symbioza? Debata «Schülerkreis» Josepha Ratzingera nad relacją stworzenie-ewolucja”, Tarnowskie Studia Teologiczne 2013, t. 32, nr 1, s. 37-38 [33-46], https://tiny.pl/g26vr (23.12.2018).

${ }^{54}$ Plantinga, „Naturalizm metodologiczny...”, s. 49. Por. też Cornelius G. Hunter, „Dlaczego teoria ewolucji nie spełnia kryterium naukowości”, przeł. Izabela Janus, Filozoficzne Aspekty Genezy 2012, t. 9, s. 77 [53-78], https://tiny.pl/xh2p2 (18.12.2018); Grzegorz MALEC, „Naturalizm metodologiczny w sporze ewolucjonizmu z kreacjonizmem w świetle poglądów Paula K. Feyerabenda", Filozoficzne Aspekty Genezy 2012, t. 9, s. 139 [131-154], https://tiny.pl/xhzfm (21.12. 2018); Dariusz S SAGAN, ,Wspólnota pochodzenia jako argument w sporze darwinizm-teoria inteligentnego projektu”, Diametros 2013, nr 37, s. 133-134 [127-145], https://tiny.pl/q336h (21.12. 2018); Dariusz Sagan, „Teoria inteligentnego projektu a ewolucjonizm”, Kwartalnik Filozoficzny 2013, t. 41, z. 2, s. 84-85 [75-96], https://tiny.pl/q336x (21.12.2018); Dariusz SAGAN, „Retoryczna historia Ruchu Inteligentnego Projektu”, Diametros 2005, nr 4, s. 80-81 [76-85], https://tiny.pl/xh 
Obrońcy zaś przyznają, że w rzeczy samej „darwinizm odzwierciedla silną ideologię”. „Co więcej”, dodają, „,należy być z niej dumnym”, ${ }^{55}$ gdyż

jasne już jest, iż wszystkie obiektywne zjawiska historii życia można wyjaśnić czynnikami czysto naturalistycznymi. ${ }^{56}$

Czy się to komuś podoba, czy nie, ewolucja miała miejsce, ${ }^{57}$

[i dlatego] ewolucjoniści nie poszukują już dowodów potwierdzających sam fakt ewolucji. Współczesne badania skupiają się raczej na pogłębionym i szczegółowym wyjaśnianiu, jak proces ewolucji zachodzi i jak przebiegał w przeszłości. ${ }^{58}$

Ewolucja zatem ,jest faktem, faktem, FAKTEM", ${ }^{59}$ zaś

„oficjalna nauka” ma merytoryczne powody, by jednomyślnie popierać paradygmat ewolucyjny, ${ }^{60}$

h8f (21.12.2018); Dariusz SAGAN, „Ewaluacja ewolucjonistycznych rozwiązań problemu nieredukowalnej złożoności", Otwarte Referarium Filozoficzne 2009, t. 2, s. 89 [89-116], https://tiny.pl/q 3mjg (21.12.2018); Dariusz SAGAN, Spór o nieredukowalną złożoność układów biochemicznych, Biblioteka Filozoficznych Aspektów Genezy, t. 5, Wydawnictwo MEGAS, Warszawa 2008, s. 1-2, 16, https://tiny.pl/qzq8p (22.12.2018).

${ }^{55}$ Michael Ruse, Darwinism Defended: A Guide to the Evolution Controversies, AddisonWesley, Reading, Massachusetts 1982, s. 280.

${ }^{56}$ George Gaylord Simpson, The Meaning of Evolution: A Study of the History of Life and of Its Significance for Man, rev. ed., The Terry Lectures Series, Yale University Press, New Haven 1976, s. 344. Fragment w przekładzie Kazimierza Jodkowskiego w: Phillip E. Johnson, „Reguły rozumowania darwinizmu”, w: JoDKowski, Metodologiczne aspekty..., s. 464 [460-472], https://tiny.pl/tqwn7 (21.12.2018).

${ }^{57}$ Wypowiedź Lawrence'a M. Kraussa, dziekana Wydziału Fizyki w Case Western Reserve University, przytaczana za: Ian FIsHeR, „Professor-Turned-Pope Leads a Seminar on Evolution”, New York Times 2 September 2006, https://tiny.pl/gkf7n (25.12.2018). Por. też SAGAN, „Debata Benedykta...", s. 10.

${ }^{58}$ Francisco J. Ayala, Dar Karola Darwina dla nauki i religii, przeł. Piotr Dawidowicz, Wydawnictwa Uniwersytetu Warszawskiego, Warszawa 2009, s. 75. Por. też SAGAN, „Wspólnota pochodzenia...", s. 129.

${ }^{59}$ Ruse, Darwinism Defended..., s. 58. Por. też John RenNIE, „15 odpowiedzi na nonsensowne tezy kreacjonistów”, przeł. Karol Sabath, Świat Nauki 2002, nr 9, s. 67 [66-72], https://tiny.pl/ gzpws (22.12.2018)

${ }^{60}$ Karol SABATH, „Kreacjonizm a sprawa polska”, Świat Nauki 2002, nr 9, s. 73, https://tiny.pl /gzpws (22.12.2018). 
największą teorię naukową stworzoną przez człowieka, ${ }^{61}$

gdyż teoria ta ,jest pewna, jak szwajcarski bank", ${ }^{62}$, ,jest to po prostu prawda”. ${ }^{63}$ „Nie można [zatem] być naukowcem, jeśli nie wierzy się w ewolucję". ${ }^{64}$ Gdyby jednak, jakimś trafem,

okazało się, że życie nie powstało w drodze ewolucji na Ziemi (i na przykład pierwsze żywe komórki sprzed miliardów lat to dzieło kosmitów), wciąż mielibyśmy solidne dowody późniejszej ewolucji, zgromadzone w wielu badaniach procesów mikro- i makroewolucyjnych. ${ }^{65}$

Przez niektórych zwolenników naturalizm uznawany jest za podejście neutralne wobec wszystkich religii, gdyż „,milczy na temat tego, czy Bóg (uznany za istotę nadprzyrodzoną) istnieje". ${ }^{66}$

Milczenie takie, na co zwrócono uwagę, nie jest jednak oznaką neutralności:

Jeśli [...] przyjmiemy, że teoria darwinowska to dwa twierdzenia — że wszystkie organizmy pochodzą od wspólnego przodka oraz że dobór naturalny był ważną przyczyną wszystkich podobieństw i różnic, jakie obserwujemy wśród organizmów - to łatwo pokazać, że wpada ona w konflikt z poglądem religijnym, według którego przy-

\footnotetext{
${ }^{61}$ Wypowiedź Johna Ecclesa w: Wojciech Chudziński i Dorota RYBicka, „Mózg a świadomość - wywiad z prof. Johnem Ecclesem", opracowanie na podstawie Paris Match, infra.org.pl 24 lipca 2012, https://tiny.pl/g8zc3 (23.12.2018).

${ }^{62}$ David Quammen, „Czy Darwin się mylił?”, National Geographic Polska 2004, nr 11 (62), s. 8 [2-33]. Por. też Dariusz SAGAN, „Molekularny «zegar Paleya» a darwinowska ewolucja”, Ruch Filozoficzny 2005, t. 42, nr 2, s. 290 [289-304], https://tiny.pl/xh8tk (21.12.2018); SAGAN, „Ewaluacja ewolucjonistycznych...”, s. 89; Małgorzata GAZDA, „Pochodzenie życia. Krytyka teorii świata RNA w świetle badań laboratoryjnych dotyczących nieenzymatycznej syntezy rybonukleotydów", Filozofia Nauki 2015, nr 3 (91), s. 114 [113-131], https://tiny.pl/tqwns (21.12.2018).

${ }^{63}$ Jerry A. Coyne, Ewolucja jest faktem, przeł. Marcin Ryszkiewicz i Wiesław Studencki, Na Ścieżkach Nauki, Prószyński i S-ka, Warszawa 2009, s. 14.

${ }^{64}$ Wypowiedź Jamesa Watsona w: Łukasz Minarowski, „Nie wszystko trzeba wiedzieć (wywiad z Jamesem Deweyem Watsonem)", Medyk Białostocki 2008, nr 67-68, s. 7 [5-8], https://tiny .pl/g26v5 (24.12.2018).

${ }^{65}$ RenNIE, „15 odpowiedzi...”, s. 69.

${ }^{66}$ Elliott SoBER, „Teoria inteligentnego projektu a nadnaturalizm — o tezie, że projektantem może być Bóg lub istoty pozaziemskie”, przeł. Sławomir Piechaczek, Filozoficzne Aspekty Genezy 2007/2008, t. 6/7, s. 37 [21-39], https://tiny.pl/xhn85 (21.12.2018).
} 
najmniej za niektóre podobieństwa i różnice odpowiadają akty stwórcze Boga. ${ }^{67}$

Dlatego inni zwolennicy naturalizmu nie uznają tego podejścia za neutralne i wyraźnie podkreślają, że

ewolucja biologiczna jest jedną z tych nielicznych koncepcji naukowych, które nie są neutralne światopoglądowo, ponieważ w bezpośredni sposób wchodzi w konflikt $\mathrm{z}$ całą gamą wierzeń religijnych. ${ }^{68}$

Podsumowując rozważania nad światopoglądowymi aspektami naturalistycznych EUO, ${ }^{69}$ powiedzieć należy, że w ramach tych EUO funkcjonuje coś, co jest pewnego rodzaju analogią do świętych ksiąg nadnaturalistycznego interwencjonizmu. Współczesna nauka również ma swoją „świętą księgę”, której treść jest powszechnie akceptowana. Jednakże sama „księga” widoczna jest dopiero wtedy, gdy działania uczonych zestawi się z tym, co robią kreacjoniści. ${ }^{70}$ (Ci ostatni, o czym już była mowa, dopasowują dane naukowe do swoich świętych ksiąg.) ,Księgą” tą jest metodologiczny naturalizm. ${ }^{71}$

Wszystkim zwolennikom teorii ID wspólne jest przekonanie, w myśl którego

Wszechświata nie można wyjaśnić wyłącznie w kategoriach naturalistycznych, i że

\footnotetext{
${ }^{67}$ Kazimierz JodKowski, „Czy teoria inteligentnego projektu posiada konsekwencje, dotyczące istnienia nadnaturalnego projektanta? Polemika z Elliottem Soberem”, Filozoficzne Aspekty Genezy 2007/2008, t. 6/7, s. 47 [41-49], https://tiny.pl/tqwn3 (22.12.2018).

${ }^{68}$ BorczYк, „Dlaczego teoria...”, s. 102.

${ }^{69}$ Kazimierz Jodkowski wyróżnił dwie odmiany naturalistycznych EUO. W myśl tego ujęcia EUO naturalizmu antynadnaturalistycznego scharakteryzować można $\mathrm{w}$ następujący sposób: przyczynom naturalnym przeciwstawia się tu przyczyny nadprzyrodzone (nadnaturalne). Zaś EUO naturalizmu antyartyficjalistycznego to nakaz przyjmowania wyłącznie wyjaśnień odwołujących się do przyczyn naturalnych, któremu towarzyszy zakaz dopuszczania wyjaśnień przez przyczyny inteligentne i celowe (por. Kazimierz JoDKowsKI, „Antynaturalizm teorii inteligentnego projektu", Roczniki Filozoficzne 2006, t. 54, nr 2, s. 73 [63-76], https://tiny.pl/qzq86 (22.12. 2018); KiLIAN, „Geneza idei...”, s. 159-166.

${ }^{70}$ Por. wypowiedź Kazimierza Jodkowskiego w: Piotr ByLıcA, Kazimierz Jodkowski, Krzysztof J. Kilian i Dariusz Sagan, „Dyskusja nad artykułem Adama Groblera, «Słabości eksplanacyjne teorii inteligentnego projektu»", Filozoficzne Aspekty Genezy 2013, t. 10, s. 53 [17-63], https://ti ny.pl/q3m1m (22.12.2018).

${ }^{71}$ Por. Jodkowski, „Uczony w ciemnym...”, s. 59.
} 
wyjaśnienie pewnych jego cech, począwszy od subtelnego zestrojenia praw i stałych fizycznych, a na specyficznych strukturach biologicznych i organizmach skończywszy, wymaga odwołania do przyczyny inteligentnej. ${ }^{72}$

Głównym problemem tej teorii jest to,

jak zapewnić obiektywną podstawę subiektywnemu — na pierwszy przynajmniej rzut oka - wrażeniu, że pewne rzeczy, w przeciwieństwie do innych, wyglądają na zaprojektowane. ${ }^{73}$

O istnieniu projektu wnioskuje się wyłącznie na podstawie oznak inteligencji: ${ }^{74}$

Wnioskowanie o projekcie to czysta indukcja a posteriori, oparta na bezwzględnie konsekwentnym zastosowaniu logiki analogii. Wniosek może mieć religijne konsekwencje, ale sam nie zależy od religijnych założeń. ${ }^{75}$

Zasadniczym przedmiotem badań teoretyków projektu są takie zjawiska przyrodnicze, o których można przypuszczać, że są skutkami działania inteligencji. ${ }^{76}$ Teoria inteligentnego projektu nie zajmuje się zatem identyfikowaniem

\footnotetext{
${ }^{72}$ Dariusz SAGAn, „Teoria inteligentnego projektu - argumenty za i przeciw”, w: Stanisław Janeczek, Anna Starościc, Dariusz DąBek i Justyna Herda (red.), Filozofia przyrody, Dydaktyka Filozofii, t. 3, Wydawnictwo Katolickiego Uniwersytetu Lubelskiego, Lublin 2013, s. 346 [335383], https://tiny.pl/q336w (22.12.2018); Francis J. ВескwIтн, Taking Rites Seriously: Law, Politics, and the Reasonableness of Faith, Cambridge University Press, New York 2015, s. 144. W tej ostatniej pracy (s. 144-147) odnaleźć można też pewne zastrzeżenia wobec takiego ujmowania cechy wspólnej ID.

${ }^{73}$ Por. David W. SNOKE, ,Jak w zaprojektowanym Wszechświecie zdefiniować to, co niezaprojektowane”, przeł. Dariusz Sagan, Filozoficzne Aspekty Genezy 2009/2010, t. 6/7, s. 132-133 [117-137], https://tiny.pl/xhnms (22.12.2018). Por. też Dariusz SAGAN, „Spór o użyteczność teorii inteligentnego projektu dla nauki”, Kultura i Edukacja 2013, nr 3 (96), s. 28-49, https://tiny.pl/xh hg3 (22.12.2018); SAGAN, „Wnioskowanie o projekcie...”, s. 166.

${ }^{74}$ Por. SAGAN, „Wnioskowanie o projekcie...”, s. 162; Dariusz SAGAN, „Zarzut nietestowalności teorii inteligentnego projektu", Studia Philosophica Wratislaviensia 2013, vol. 8, fasc. 3, s. 44 [43-59], https://tiny.pl/q33s3 (23.12.2018).

${ }^{75}$ Michael Denton, Evolution: A Theory in Crisis, Burnett Books, London 1985, s. 341 (cyt. za: Jonathan WITT, „Zarys historii powstania naukowej teorii inteligentnego projektu”, przeł. Dariusz Sagan, Na Początku... 2005, nr 9-10 (198-199), s. 356 [352-362], https://tiny.pl/xhh8q [22. 12.2018]).

${ }^{76}$ Por. SAGAN, „Teoria inteligentnego projektu — argumenty...”, s. 349.
} 
projektanta. Jego natura, motywy i sposoby działania również nie są jej przedmiotem badania. ${ }^{77}$ Jest ona „opcją neutralną” w tym sensie, że da się uzgodnić zarówno z naturalizmem, jak i nadnaturalizmem. ${ }^{78}$

Odnotować w tym miejscu warto, że tak rozumiany wariant teorii inteligentnego projektu określany jest mianem „wersji minimalistycznej” lub „teorią mini-ID”. Dzięki temu, że nie wygłasza się tez o naturze projektanta, ma to być ujęcie, które jest możliwe do zaakceptowania przez ludzi o odmiennych światopoglądach. ${ }^{79}$ Innym, zdaniem niektórych ważniejszym, powodem propagowania tej wersji jest obejście w USA konstytucyjnego zakazu propagowania religii w szkołach państwowych. ${ }^{80}$

\footnotetext{
${ }^{77}$ Por. np. SAGAN „Problem religijnego...”, s. 55; Dariusz SAGan, Metodologiczno-filozoficzne aspekty teorii inteligentnego projektu, Biblioteka Filozoficznych Aspektów Genezy, t. 6, Instytut Filozofii Uniwersytetu Zielonogórskiego, Zielona Góra 2015, s. 7, https://tiny.pl/g7m72 (22.12.2018); SAGAN, „Wnioskowanie o projekcie...”, s. 153-154, 157-161. Por. też Adam Grobler, „Słabości eksplanacyjne teorii inteligentnego projektu”, Filozoficzne Aspekty Genezy 2013, t. 10, s. 10-12 [7-16], https://tiny.pl/xh8ls (22.12.2018); wypowiedź Dariusza Sagana w: Bylica, Jodkowski, Kilian i Sagan, „Dyskusja nad artykułem Adama Groblera...”, s. 20, 23-24; Dariusz SAGAN, „Spór o możliwość wykrywania projektu w naukach przyrodniczych”, Scientia et Fides 2015, vol. 3, nr 1, s. 98-102 [87-113], https://tiny.pl/gz16f (23.12.2018); Casey Luskin, „Teoria inteligentnego projektu nie wypowiada religijnych twierdzeń o sferze nadnaturalnej”, przeł. Izabela Janus, Filozoficzne Aspekty Genezy 2009/2010, t. 6/7, s. 97-99 [93-116], https://tiny .pl/xhnlg (22.12.2018); SNOKE, „Jak w zaprojektowanym...”, s. 121; Robert CAMP, „Czy teoria inteligentnego projektu może być naukowa w tym samym sensie, co program SETI?”, przeł. Piotr Wołkowski, Filozoficzne Aspekty Genezy 2009/2010, t. 6/7, s. 166-167 [161-173], https://tiny.p1/ xh8hl (26.12.2018).

${ }^{78}$ Por. Andrzej Wiśniewski, „Dlaczego należy czytać Jodkowskiego?”, w: Bylica, Kilian, Piotrowski i Sagan (red.), Filozofia - nauka — religia..., s. 40 [37-41], https://tiny.pl/g268h (23. 12.2018). Por. też Dariusz SAGAN, „O programie badawczym teorii inteligentnego projektu”, Filozoficzne Aspekty Genezy 2013, t. 10, s. 73-74 [73-108], https://tiny.pl/q3369 (28.12.2018); SAGAN, „Spór o użyteczność...”, s. 28; SAGAN, „Zarzut nietestowalności...”, s. 43; Dariusz SAGan, „Wyjaśnianie za pomocą praw przyrody jako warunek naukowości w sporze o ewolucję i inteligentny projekt", Studia Philosophiae Christianae 2013, t. 49, nr 1, s. 108-109 [93-116], https://tiny.pl/q3 $36 \mathrm{~g}$ (23.12.2018); Dariusz SAGAN, „Argument z niedoskonałości i zła w kontekście sporu o ewolucję i inteligentny projekt", Logos i Ethos 2013, nr 1 (34), s. 132-133, 142-143 [129-148], https:// tiny.pl/q336m (23.12.2018); Kazimierz JodKowski, „Wstęp do teorii inteligentnego projektu”, Fronda 2012, nr 63, s. 24 [16-32], https://tiny.pl/gkfbn (23.12.2018); Richard THoRnHILL, „Historyczny związek między darwinizmem a argumentem z biologicznego projektu”, przeł. Anna Droś, Natalia Górska, Mateusz Krzyżanowski, Renata Merda, Zofia Sadowska i Dariusz Sagan, Filozoficzne Aspekty Genezy 2012, t. 9, s. 95 [79-105], https://tiny.p1/gzlnb (23.12.2018).
}

${ }^{79}$ Por. Sober, „Teoria inteligentnego...”, s. 22-23; BorczyK, „Dlaczego teoria...”, s. 105. 
Zwolennicy ID widzą sprawę inaczej:

Fakt, że teoria inteligentnego projektu nie identyfikuje źródła projektu, nie jest polityczną kalkulacją, lecz myśleniem [...] nie wykraczającym poza to, co mówią świadectwa empiryczne. ${ }^{81}$

ID da się uzgodnić z naturalizmem. Świadczą o tym następujące przekonania: następstwem okresowej ingerencji w ziemskie organizmy pozaziemskiego materiału genetycznego były tak zwane „burze genetyczne” (krótkotrwałe w stosunku do trwania gatunków procesy przetasowania ziemskiego i pozaziemskiego materiału genetycznego), których wynikiem były procesy makroewolucyjne, ${ }^{82}$ lub zarodniki życia przedostały się na Ziemię w statku kosmicznym wysłanym przez obcą cywilizację. ${ }^{83}$

Można ją również uzgodnić z nadnaturalizmem. Świadczy o tym następujące przekonanie: do wygenerowania złożoności i różnorodności świata przyrod-

\footnotetext{
${ }^{80}$ Por. SoBer, „Teoria inteligentnego...”, s. 23-24. Por też komentarz do takiego ujęcia w: Jodкоwski, „Czy teoria inteligentnego...”, s. 45.

${ }^{81}$ WIтT, „Zarys historii...”, s. 356.

${ }^{82}$ Por. np. Fred Hoyle, Matematyka ewolucji, przeł. Robert Piotrowski, Wydawnictwo MEGAS, Warszawa 2003, s. 138-140; Hoyle and Wickramasinghe, Evolution from Space..., s. 130; SŁow ik i Kilian, „Hoyle i matematyczne...”, s. 396-399; Kazimierz JodKowski, „Fred Hoyle (1915-2010)", w: HoyLe, Matematyka ewolucji..., s. 30-31 [25-36], https://tiny.pl/gsxrw (25.12. 2018); Dean H. KenYon, „Kreacjonistyczne ujęcie pochodzenia życia”, przeł. Kazimierz Jodkowski, w: Jodkowski, Metodologiczne aspekty..., s. 484 [482-495], https://tiny.pl/qm4xj (25.12. 2018).

${ }^{83}$ Por. Francis Crick, Life Itself: Its Origin and Nature, Simon \& Schuster, New York 1981, s. 15-16; Jоркошькі, Metodologiczne aspekty..., s. 176; Ejaz Alı, „Summary of Life Itself”, Eukaryon 2009, vol. 5, s. 17 [17-18], https://tiny.pl/g279j (25.12.2018); JoDKOwskI, „Darwinowska teoria...”, s. 22; Dariusz SAGAN, „Teoria inteligentnego projektu a naukowa debata nad pochodzeniem", w: Kazimierz Jоркошsкі (red.), Teoria inteligentnego projektu - nowe rozumienie naukowości?, Biblioteka Filozoficznych Aspektów Genezy, t. 2, Wydawnictwo MEGAS, Warszawa 2007, s. 82 [79-122], https://tiny.pl/qzq8f (25.12.2018); Dariusz SAGAN, „Teoria inteligentnego projektu a kreacjonizm", Kwartalnik Filozoficzny 2015, t. 43, z. 2, s. 139-143 [131-150], https:// tiny.pl/g2vmx (25.12.2018); SAGAN, „Teoria inteligentnego projektu a ewolucjonizm...”, s. 83; SAGAN, Spór o nieredukowalną złożoność..., s. 14-15; Piotr BYLICA, „Testowalność teorii inteligentnego projektu”, Filozofia Nauki 2003, nr 2 (42), s. 41 [41-49], https://tiny.pl/q3m11 (25.12. 2018); Tomasz Krause, „Filozoficzne aspekty tzw. «afery Kansas»”, Filozoficzne Aspekty Genezy 2004, t. 1, s. 146-148 [143-224], https://tiny.pl/g2863 (25.12.2018); John D. MorRIS, ,Jak powstało życie?”, przeł. Mieczysław Pajewski, Serwis Internetowy Polskiego Towarzystwa Kreacjonistycznego, https://tiny.pl/tqdnp (25.12.2018).
} 
niczego nie wystarczą procesy naturalne i musi wspomagać je wyższa, utożsamiana z Bogiem, inteligencja. ${ }^{84}$

Także w stosunku do ID pojawiają się zarzuty, że ma światopoglądowy lub ideologiczny charakter. Umieszcza się ją w perspektywie teistycznej:

ID bez wątpienia mieści się w ramach tradycyjnego teizmu [...], ID jest wiarą w twórczą, celową działalność nadnaturalnego bóstwa, ${ }^{85}$

lub też wprost mówi się o niej jako o kiepskiej ideologii:

Ideologia ta nie tylko wskrzesza dawne teologiczne błędy manicheizmu, ale jest również sprzeczna z naukowym rozumieniem Wszechświata. ${ }^{86}$

\footnotetext{
${ }^{84}$ Por. np. CSSHS Editorial Staff, „Lesson 3...”; Denis O. Lamoureux, „Evolutionary Creation: Moving Beyond the Evolution versus Creation Debate”, Christian Higher Education 2010 , vol. 9, s. 32-33 [28-48], https://tiny.pl/th3kl (12.12.2018). Por. też JodKowski, „Antynaturalizm teorii...”, s. 71; Kazimierz JoDKowskI, „Klasyfikacja stanowisk kreacjonistycznych”, Filozoficzne Aspekty Genezy 2005/2006, t. 2/3, s. 256 [241-269], https://tiny.pl/q3m54 (25.12.2018); SAGAN, „Teoria inteligentnego projektu a naukowa...”, s. 80; wypowiedź Małgorzaty Gazdy w: Piotr Bylica, Małgorzata Gazda, Kazimierz Jodkowski, Krzysztof J. Kilian i Dariusz Sagan, „Dyskusja nad artykułem Adama Trybusa, «Program badawczy SETI a teoria inteligentnego projektu»", Filozoficzne Aspekty Genezy 2016, t. 13, s. 223 [211-242], https://tiny.pl/g8nvh (25.12.2018); David W. SNOKE, „Biologia systemowa jako paradygmat badawczy teorii inteligentnego projektu”, przeł. Dariusz Sagan, Filozoficzne Aspekty Genezy 2015, t. 12, s. 256 [255-285], https://tiny.pl/tqdn6 (25.12.2018).

${ }^{85}$ Matthew J. Brauer, Barbara Forrest, and Steven G. Gey, „Is It Science Yet?: Intelligent Design Creationism and the Constitution”, Washington University Law Review 2005, vol. 83, no. 1, s. 33 [1-150], https://tiny.pl/g2vm1 (25.12.2018).

${ }^{86}$ Michał Heller, „Konieczność i przypadek w ewolucji Wszechświata”, Zagadnienia Filozoficzne w Nauce 2009, vol. 44, s. 11 [3-12], https://tiny.pl/g2vml (25.12.2018). Por. też Michał Heller, „Rzeczy najważniejsze” (Przemówienie wygłoszone przez ks. Michała Hellera 12 marca 2008 r. w Nowym Jorku z okazji przyznania mu Nagrody Templetona), w: Bartosz Brożek i Janusz MĄсzKa (red.), Czy nauka zastąpi religię?, Copernicus Center Press, Kraków 2011, s. 14 [11-14]; Michał Heller, Łukasz Kwiatek i Mateusz Hohol, „Wielka Matryca i herezja Inteligentnego Projektu - rozmowa z Michałem Hellerem", Nauka i Religia.PL 12 stycznia 2013, https:// tiny.pl/tqdkq (25.12.2018). Por. też komentarz do tej tezy: Marek SŁoмKA, „Powrót inteligentnego projektanta. Uwagi polemiczne do artykułu Dariusza Sagana «Filtr eksplanacyjny: wykrywanie inteligentnego projektu na gruncie nauk przyrodniczych»", Roczniki Filozoficzne 2009, t. 57, nr 1, s. 344 [341-345], https://tiny.pl/tqdkx (25.12.2018); Dariusz SAGAN, „Odpowiedź na uwagi polemiczne ks. dra Marka Słomki do mojego artykułu o filtrze eksplanacyjnym”, Roczniki Filozoficzne 2009, t. 57, nr 1, s. 347 [345-349], https://tiny.pl/xhzm6 (25.12.2018).
} 
Tego typu zarzuty mają dyskwalifikować ją w oczach jej, na ogół naturalistycznych, ${ }^{87}$ przeciwników. ${ }^{88}$

Dość powszechnie ID utożsamiana jest też z kreacjonizmem i jego światopoglądowymi konsekwencjami: ${ }^{89}$

Jest [ona] jedynie najnowszą taktyką ,prawicy religijnej”, mającą na celu posłużyć się rządem, by narzucić „kreacjonizm” niczego nie podejrzewającym studentom i nauczycielom. ${ }^{90}$

Podstawową metodą kreacjonizmu inteligentnego projektu [trzeciej generacji teorii kreacjonistycznej] jest: unikanie słowa „Bóg”, porzucenie wielu kontrowersyjnych szczegółów wcześniejszych wersji kreacjonizmu, koncentracja na rzekomych problemach teorii ewolucji, unikanie afirmatywnego, alternatywnego podejścia do kwestii, które nazbyt mocno pokrywają się z wersją stworzenia z Księgi Rodzaju. ${ }^{91}$

\footnotetext{
${ }^{87}$ Islamski kreacjonista Harun Yahya uznaje teorię inteligentnego projektu za „pułapkę Szatana”, ponieważ nie utożsamia ona projektanta z Allahem. (Tylko ten ostatni może samodzielnie tworzyć coś z niczego.) Zaś Świadkowie Jehowy milczenie teoretyków projektu w sprawie tożsamości projektanta uznają za „rażące pominięcie” (por. SAGAN, „Teoria inteligentnego projektu a kreacjonizm...”, s. 145-146; Dariusz SAGAN, „Kazimierz Jodkowski o teorii inteligentnego projektu", w: Bylica, Kilian, Piotrowski i Sagan (red.), Filozofia - nauka - religia..., s. 218 [213227], https://tiny.pl/tqdkr [25.12.2018]; Harun YAHYa, Design in Nature, Ta-Ha Publishers Ltd., London 2004, s. 138, https://tiny.pl/tqjg6 [25.12.2018]).

${ }^{88}$ Por. SAGAN, „Problem religijnego...”, s. 56.

${ }^{89}$ Por. np. Kenneth R. MiLler, „Darwin, projekt i wiara katolicka”, przeł. Adam Grzybek, Filozoficzne Aspekty Genezy 2005/2006, t. 2/3, s. 36 [35-38], https://tiny.pl/g2vmn (25.12.2018); Barbara C. ForRest, „Inside Creationism's Trojan Horse: A Closer Look at Intelligent Design”, Georgia Journal of Science 2005, vol. 63, no. 3, s. 153-161 [153-166], https://tiny.pl/g2vmk (25.12.2018); John V. AlifF, „Teaching Evolution and the Challenge of Intelligent Design: A Symposium", Georgia Journal of Science 2005, vol. 63, no. 3, s. 145-146 [144-152], https://ti ny.pl/tqdkc (25.12.2018); Taner EDIs, „Dlaczego «teoria inteligentnego projektu» jest bardziej interesująca niż tradycyjny kreacjonizm", przeł. Dariusz Sagan, Filozoficzne Aspekty Genezy 2007/ 2008, t. 6/7, s. 81 [81-93], https://tiny.pl/xh8mc (25.12.2018); Wттт, „Zarys historii...”, s. 352353; SAGAN, „Problem religijnego...”, s. 57-64; SAGAN, „Teoria inteligentnego projektu — argumenty...", s. 344-345.

${ }^{90}$ John G. WEST, „Teoria inteligentnego projektu jest wyjątkowo źle rozumiana”, przeł. Dariusz Sagan, Na Poczatku... 2005, nr 11-12A (200-201), s. 458 [458-460], https://tiny.pl/xh4zj (23.12.2018). Por. też SAGAN, Spór o nieredukowalną złożoność..., s. 16-17.

${ }^{91}$ Brauer, Forrest, and Gey, „Is It Science Yet...”, s. 20 (fragment zaznaczony nawiasem kwadratowym pochodzi ze strony 19).

Zdaniem autorów (s. 20-21) dwie poprzednie generacje teorii kreacjonistycznej silnie opierają się na pierwszym rozdziale Księgi Rodzaju. Różni je to, że generacja pierwsza wszystkie swoje
} 
A jeśli już nie jest utożsamiana, to uznawana jest „,za religię podszywającą się pod naukę": ${ }^{92}$

Teoria inteligentnego projektu jest tylko kolejnym wyrażeniem na określenie religii. ${ }^{93}$

Mówi się też, że jest to podejście „znacznie bardziej niebezpieczne niż poglądy tradycyjnego kreacjonizmu", ${ }^{94}$ gdyż: (a) niektóre tezy ID formułowane są przez wykwalifikowanych naukowców, zatem łatwiej mogą stać się częścią nauki niż tezy kreacjonistyczne; (b) tezy ID, dotyczące wykrywania inteligentnych przyczyn, łączone są z tymi dziedzinami nauki, które zajmują się wykrywaniem inteligentnych przyczyn, co jeszcze mocniej wzmacnia przekonanie, że ID to teoria o naukowym charakterze; (c) tezy ID niosą ze sobą zagrożenie kulturowe,

ponieważ jednym z celów ID — wyrażonym przez Discovery Institute [...] — jest zdetronizowanie królującej filozofii materializmu. ${ }^{95}$

\section{Twierdzi się też, że ID opiera się}

na nieporozumieniu, polegającym głównie na niezrozumieniu roli przypadku w strukturze i ewolucji Wszechświata ${ }^{96}$

i jest powrotem „do czasów, kiedy ruch planety thumaczono interwencją anioła". ${ }^{97}$ Jest też niczym innym niż

wnioski dotyczące mechanizmów powstania świata materialnego i organicznego wyprowadza bezpośrednio z Genesis. Zaś generacja druga unika tego typu wniosków, w ich miejsce wprowadzając naukowe świadectwa na rzecz kreacjonizmu i próbując jednocześnie umieścić naukowy kreacjonizm w akademickich programach nauczania.

${ }^{92}$ Por. Ryland, „«Teoria inteligentnego projektu»...”, s. 414. Por. też BraUER, Forrest, and GeY, „Is It Science Yet...”, s. 28-31.

${ }^{93}$ Wypowiedź Jamesa Watsona w: Minarowski, „Nie wszystko...”, s. 6.

${ }^{94}$ Thomas WoODWARD, „Istota sporu darwinizmu z teorią inteligentnego projektu: przyrodnicza symfonia makroewolucji”, przeł. Dariusz Sagan, Filozoficzne Aspekty Genezy 2007/2008, t. 6/7, s. 8 [7-20], https://tiny.pl/xhnkv (25.12.2018).

${ }^{95}$ Woodward, „Istota sporu...”, s. 8. Por. też Jodkowski, „Wstęp do teorii...”, s. 24.

${ }^{96}$ Por. Heller, „Konieczność i przypadek...”, s. 3.

${ }^{97}$ Por. SŁomKa, „Powrót inteligentnego...”, s. 344. Por. też komentarz do tej tezy: SAGan, „Odpowiedź na uwagi...”, s. 348-349. 
starym błędem podniesionym do kwadratu — bo w tym przypadku bezpośrednim działaniem Boga wyjaśnia się już nie to, co jest dziurą w naukowej wiedzy o świecie, ale to, co nauka sama jest w stanie skutecznie wyjaśnić. ${ }^{98}$

Zaś jej zwolennicy reprezentują postawę antyoświeceniową — która prowadzi do literalizmu i biblijnego moralizowania ${ }^{99}$ — oraz ,metodologiczną ignorancję i obskurantyzm”. ${ }^{100}$ Mówi się również, że podczas gdy „nauka jest filozofią odkrycia, [to] ID jest filozofią niewiedzy”. ${ }^{101}$ Zwolennicy ID

zagrażają [też] samej naturze nauki, naszemu systemowi edukacyjnemu, a nawet naszej formie sprawowania władzy. ${ }^{102}$

Sporadycznie jedynie pojawiają się takie wyważone oceny, jak ta:

nawet jeśli wszyscy zwolennicy teorii inteligentnego projektu prowadzą wojnę kulturową przeciwko świeckiemu społeczeństwu, to wcale z tego nie wynika, że powinniśmy odrzucić tę teorię, jeżeli pojmuje się ją jako (z grubsza mówiąc) twierdzenie, że możemy znaleźć świadectwa naukowe na rzecz istnienia kosmicznego projektanta. Powinniśmy przyjrzeć się raczej merytorycznej argumentacji tej teorii. ${ }^{103}$

Takie wyważone podejścia krytykowane są bardzo ostro, gdyż poważne traktowanie merytorycznych argumentów zwolenników ujęć nienaturalistycznych świadczy jedynie o tym, ,jak dalece wątki pseudo- i paranaukowe przeni-

\footnotetext{
${ }^{98}$ Tadeusz Pabian, „Nauka i wiara — razem czy osobno?”, Nauka i Religia.PL 29 lipca 2015, https://tiny.pl/tqdk5 (26.12.2018).

${ }^{99}$ Por. Christopher Carlisle, „Interview with Dr. Michael Ruse, Ph.D.”, w: Christopher Carlisle, M. Div. and W. Thomas SMith Jr., The Complete Idiot's Guide to Understanding Intelligent Design, Penguin Group, New York 2006, s. 277-278 [275-290]. Por. też SAGan, „Teoria inteligentnego projektu — argumenty...”, s. 340.

${ }^{100}$ Mateusz HoHоL, „Darwin jako przebrany za wroga przyjaciel religii”, Zagadnienia Filozoficzne w Nauce 2010, vol. 47, s. 161 [161-165], https://tiny.pl/tqdk4 (25.12.2018).

${ }^{101}$ Wypowiedź Neila deGrasse Tysona przytaczam za: Johnson, „A Free-for-All...”.

${ }^{102}$ Marshall Berman, „Intelligent Design Creationism: A Threat to Society — Not Just Biology”, The American Biology Teacher 2003, vol. 65, no. 9, s. 646 [646-648], https://tiny.pl/g26n5 (25.10.2018).

${ }^{103}$ Bradley Monton, Seeking God in Science: An Atheist Defends Intelligent Design, Broadview Press Inc., Toronto 2009, s. 12. Fragment w przekładzie SAGANA, „Teoria inteligentnego projektu — argumenty...", s. 343-344.
} 
kają do oficjalnego obiegu". ${ }^{104}$

W ramach artyficjalizmu twierdzi się, że znane świadectwa empiryczne z biologii i kosmologii wskazują na ślady działania inteligentnej istoty. Świadectwa te nie pozwalają na określenie jej tożsamości, ponieważ mające świadczyć na rzecz projektu fakty nie dają po temu żadnych wskazówek. Istotą taką może być zarówno jakaś istota nadprzyrodzona, jak i przedstawiciele pozaziemskich cywilizacji, co, o czym już wspominano, prowadzi do tezy, że teoria inteligentnego projektu jest zgodna $\mathrm{z}$ ateizmem i teizmem. Jednakże krytycy tej teorii utrzymują, że samo odwołanie się do kategorii inteligentnego projektu prowadzi ku tezie o ingerencji istoty nadnaturalnej. To zaś prowadzi do pogwałcenia zasady metodologicznego naturalizmu. ${ }^{105}$

\footnotetext{
${ }^{104}$ SABATH, „Kreacjonizm a sprawa...”, s. 73.

${ }^{105}$ Por. JoDKOwSKI, „Antynaturalizm teorii...”, s. 71-72; Dariusz SAGAN, „Naturalizm metodologiczny — konieczny warunek naukowości?”, Roczniki Filozoficzne 2013, t. 61, nr 1, s. 75 [7391], https://tiny.pl/q33sb (25.12.2018); SAGAN, „Teoria inteligentnego projektu — argumenty...”, s. 339-340; Stephen C. Meyer, „The Use and Abuse of Philosophy of Science: A Response to Moreland", Perspectives on Science and Christian Faith 1994, vol. 46, no. 1, s. 19-21 [19-21], https://tiny.pl/h2wcm (25.12.2018).

Próbę obrony artyficjalizmu za pomocą wprowadzenia kryterium adekwatności przyczynowej (przypomina ono zasadę wnioskowania do najlepszego wyjaśnienia: por. Steve CLARKE, „Naturalism, Science and the Supernatural", Sophia. International Journal of Philosophy and Traditions 2009, vol. 48, s. 131-136 [127-142]) przynosi ujęcie Meyera (por. Małgorzata GAzDA, „Stephena C. Meyera koncepcja «podpisu w komórce» a filozoficzne podstawy nauki”, Filozoficzne Aspekty Genezy 2016, t. 13, s. 17 [7-23], https://tiny.pl/g16kj [26.12.2018]; Małgorzata GAzDA, „Zasada naturalizmu metodologicznego czy adekwatności przyczynowej?”, Idź Pod Prąd 2015, nr 10-11 (135-136), s. 8-9 [8-9], https://tiny.pl/tqdbj [26.12.2018]). W myśl tego ujęcia w nauce należy przyznawać wyższość takim wyjaśnieniom przyczynowym, które odwołują się do przyczyn mających, dzięki niezależnemu potwierdzeniu doświadczalnemu, zdolność do wywoływania określonych skutków. Zdaniem Meyera zasada ta pozwala przyjąć, że

inteligentne zaprojektowanie trzeba uznać za co najmniej możliwe naukowe wyjaśnienie pochodzenia informacji biologicznej.

Stephen C. Meyer, Signature in the Cell: DNA and the Evidence for Intelligent Design, Harper One, New York 2009, s. 171 (cyt. za: GazdA, „Stephena C. Meyera...”, s. 17). Por. też SAGAN, „Wyjaśnianie za pomocą...”, s. 96-105; SAGAN, „Spór o możliwość...”, s. 106; SAGAN, „Teoria inteligentnego projektu — argumenty...”, s. 362-363.

Szereg już sformułowanych uwag na temat mechanizmów funkcjonowania EUO (por. np. JodKowski, „Eskapizm teologii...”, s. 273-274; BYLICA, Wspólczesny teizm..., s. 28-29; wypowiedź Krzysztofa Kiliana w: Bylica, Gazda, Jodkowski, Kilian i Sagan, „Dyskusja nad artykułem
} 
Inne najpopularniejsze zarzuty względem ID przedstawiają się tak: nie jest ona empirycznie testowalna; nie odwołuje się do praw przyrody (nic za ich pomocą nie wyjaśnia); nie mówi nic ani o projektancie, ani o mechanizmie projektowania; nie formułuje przewidywań; nie dostarcza pozytywnych świadectw na rzecz śladów aktywności projektanta; nie prowadzi do stworzenia płodnego programu badawczego i, jako taka, nie tylko nie jest użyteczna dla nauki, ale i jest jej hamulcem; zniechęca uczonych do poszukiwań wyjaśnień naturalistycznych; opiera się na argumencie z niewiedzy; jej zwolennicy nie opublikowali ani jednego artykułu, przedstawiającego dane naukowe na rzecz istnienia projektu, w specjalistycznych czasopismach naukowych. ${ }^{106}$

Ten ostatni zarzut formułowany jest na przykład tak:

Nie ma [...] poważnych publikacji naukowych kwestionujących istnienie ewolucji. W połowie lat dziewięćdziesiątych George W. Gilchrist z University of Washington w tysiącach czasopism specjalistycznych poszukiwał artykułów o ,inteligentnym projekcie” lub „kreacjonizmie naukowym”. Nie znalazł ani jednego. Równie bezowocne były prowadzone w ciągu ostatnich dwóch lat niezależne poszukiwania Barbary Forrest z Southeastern Louisiana University i Lawrence'a M. Kraussa z Case Western Reserve University. ${ }^{107}$

Adama Trybusa...”, s. 8-9; wypowiedź Dariusza Sagana w: Bylica, Gazda, Jodkowski, Kilian i SAGAN, „Dyskusja nad artykułem Adama Trybusa...”, s. 22-23) pozwala w tym miejscu na pewne spostrzeżenie. Bez względu na to, czy Meyerowskie kryterium jest trafne, to inteligentne zaprojektowanie tak długo nie będzie uznawane za możliwe naukowe wyjaśnienie, jak długo standardy naukowości dyktowane będą przez naturalistyczne EUO.

${ }^{106}$ Por. SAGAN, „Spór o możliwość...”, s. 90-109; SAGAN, „Wnioskowanie o projekcie...”, s. 153-156, 165-176; SAGAN, „Spór o użyteczność...”, s. 30-31; SAGAN, „Teoria inteligentnego projektu - argumenty...”, s. 348-371; SAGAN, „Zarzut nietestowalności...”, s. 44-59; Dariusz SAGAN, „Zdolność przewidywania jako warunek naukowości w sporze o ewolucję i inteligentny projekt”, Zagadnienia Naukoznawstwa 2012, nr 4 (194), s. 270-274 [269-286], https://tiny.pl/q3367 (26.12. 2018); Dariusz SAGAN, „Wnioskowanie do najlepszego wyjaśnienia jako metodologiczna podstawa teorii inteligentnego projektu", Zagadnienia Naukoznawstwa 2014, nr 1 (199), s. 42-44 [4159], https://tiny.pl/tqdzx (26.12.2018); Dariusz SAGAN, „The Nature of Design Inference and the Epistemic Status of Intelligent Design”, International Philosophical Quarterly 2019, vol. 59, no. 1, s. 38-39 [37-55]; George W. Gilchrist, ,The Elusive Scientific Basis of Intelligent Design Theory”, Reports of the National Center for Science Education 1997, vol. 17, no. 3, s. 14-15 [14-15], https://tiny.pl/tqdzm (26.12.2018); Berman, „Intelligent Design...”, s. 646; Robert T. PENnock, „Creationism and Intelligent Design”, Annual Review of Genomics and Human Genetics 2003, vol. 4, s. 152 [143-163], https://tiny.pl/tqdz7 (26.12.2018).

${ }^{107}$ RenNIE, „15 odpowiedzi...”, s. 68. Por. też Berman, „Intelligent Design...”, s. 648. 
Zarzut taki rozmija się jednak z prawdą:

Eugenie Scott oraz Henry Cole w 1985 roku zwrócili się do redaktorów 68 czasopism, pytając ich, czy w latach 1980-1983 zezwolili na druk tekstów poruszających tematy ,powszechnie znajdowane w czasopismach naukowych kreacjonistów”. Wśród około 135000 artykułów Scott i Cole znaleźli jedynie (czy aż) 18 takich, które można opisać jako „broniące naukowego kreacjonizmu”. ${ }^{108}$

Należy też zauważyć, że publikacje nienaturalistyczne nie będą zamieszczane w tych czasopismach, które opowiadają się za naturalizmem (czyli, de facto, we wszystkich liczących się naukowych czasopismach na świecie) z przynajmniej dwóch powodów.

Pierwszym jest zjawisko thumienia świadectwa. Oryginalne rozwiązania, niezgodne $\mathrm{z}$ powszechnie przyjmowanym punktem widzenia $\mathrm{w}$ jakiejś dziedzinie, nie są uznawane przez społeczność uczonych, a redakcje czasopism naukowych odmawiają publikowania prac zawierających tezy niezgodne z powszechnie akceptowanymi. ${ }^{109}$

Drugim powodem, który pozostaje w bezpośrednim związku z wyżej opisanym, jest niezgodność naturalistycznych, nadnaturalistycznego i artyficjalistycznego EUO:

Nawet gdyby teoretycy projektu pieczołowicie prowadzili badania w ramach teorii inteligentnego projektu i chcieli publikować wyniki w renomowanych czasopismach naukowych, nie należałoby się raczej spodziewać, że mogłoby się to im udać, wziąwszy zwłaszcza pod uwagę, że rady naukowe czasopism zdominowane są przez naturali-

\footnotetext{
${ }^{108}$ JoDKOwsKi, Metodologiczne aspekty..., s. 244-245. (Fragmenty zaznaczone cudzysłowem pochodzą z artykułu: Eugenie ScotT and Henry Cole, „The Elusive Scientific Basis of Creation «Science»", The Quarterly Review of Biology 1985, vol. 60, s. 25, 26 [21-30], https://tiny.pl/tqd Zw [23.12.2018]. Na s. 240-247 monografii Jodkowskiego odnaleźć można więcej przykładów i uwag dotyczących publikacji kreacjonistów.) Por. też David Buckna, „Do Creationists Publish in Notable Refereed Journals?”, Creation Ministries International April 1997, https://tiny.pl/tqrjs (26.12.2018).

${ }^{109}$ Por. SŁowik i Kilian, „Hoyle i matematyczne...”, s. 402-403; Małgorzata GAZdA, „Ban na inteligentny projekt”, Idź Pod Prą 2016, nr 3-5 (139-141), s. 10, https://tiny.pl/tqdzc (26.12. 2018); Małgorzata GAzDA, „Dobór — ale czy naturalny?”, Idź Pod Prad 2015/2016, nr 12-1 (137138), s. 10 [9-10], https://tiny.pl/tqdzd (26.12.2018); Casey Luskin, „Paper Reports That Amino Acids Used by Life Are Finely Tuned to Explore «Chemistry Space»", Evolution News \& Science Today 5 June 2015, https://tiny.pl/tqdz5 (26.12.2018).
} 
stów, którzy odrzucają tę teorię już na gruncie metodologicznym. ${ }^{110}$

Wracając do najpopularniejszych względem ID zarzutów, mówi się, że „najprostszym sposobem na uwierzenie $\mathrm{w}$ teorię inteligentnego projektu jest niechodzenie do szkoły”. ${ }^{111}$ ID jest też nienaukowa. Brakuje jej również „impetu eksplanacyjnego" - po ponad dwóch dekadach badań powinna już dokądś badaczy doprowadzić ${ }^{112}-\mathrm{i}$,planu eksperymentalnego potwierdzenia”: ${ }^{113}$

Tak długo, jak długo istnieć będzie tak ogromna dysproporcja w pozytywnej argumentacji za tymi koncepcjami (przygniatająca przewaga biologii ewolucyjnej i praktycznie zerowe wsparcie dla ID), tak długo teoria ID nie dość, że nie będzie jedyna alternatywą dla biologii ewolucyjnej, to nie będzie w ogóle żadną alternatywą, niezależnie od tego, czy teoria ewolucji będzie czy nie będzie odrzuconą przez naukowców ideą. ${ }^{114}$

Mówi się nie tylko,

że głównym zagrożeniem, jakie niesie ta teoria, jest słabo kontrolowany rozwój „niewłaściwej nauki" 115

(zapewne dlatego, że ID ,jest defetystyczna" ${ }^{116} \mathrm{i}$, ,jest przejawem ,antyintelektualizmu oraz naukowego fundamentalizmu" ${ }^{117}$ ). Mówi się również, że

\footnotetext{
${ }^{110}$ SAGAN, „Teoria inteligentnego projektu — argumenty...”, s. 369.

${ }^{111}$ Wypowiedź Jamesa Watsona w: Minarowski, „Nie wszystko...”, s. 6.

${ }^{112}$ Por. SAgAN, „Spór o użyteczność...”, s. 35; BioLogos Editorial Team, „Does Intelligent
} Design Really Explain a Complex and Puzzling World?", The BioLogos 15 March 2010, https://ti ny.pl/tqdz1 (26.12.2018).

${ }^{113}$ Por. William A. Dembski, „Tematy badań w ramach teorii inteligentnego projektu”, przeł. Dariusz Sagan, Na Poczatku... 2005, nr 3-4 (192-193), s. 136 [136-146], https://tiny.pl/xhzw3 (26.12.2018).

${ }^{114}$ BorczyK, „Dlaczego teoria...”, s. 108 [wyróżnienie w oryginale].

${ }^{115}$ Por. Woodward, „Istota sporu...”, s. 9.

${ }^{116}$ Richard Dawkins, Bóg urojony, przeł. Piotr Szwajcer, Wydawnictwo CiS, Warszawa 2007, s. 184. Por. też SAGAN, „Spór o użyteczność...”, s. 31.

${ }^{117}$ Massimo Pigliucci, „Science and Fundamentalism”, EMBO Reports 2005, vol. 6, no. 12 , s. 1108 [1106-1109], https://tiny.pl/g2vmw (26.12.2018). Por. też SAGAN, „Teoria inteligentnego projektu — argumenty...", s. 340. 
precyzyjna argumentacja nie pozostawia żadnych wątpliwości, że Inteligentny Projekt z prawdziwą nauką ma niewiele wspólnego. ${ }^{118}$

Utrzymuje się także, że ID jest „kompletnym fiaskiem”, ${ }^{119}$ a jej zwolennicy

poprzestają na argumentowaniu drogą eliminacji: krytykują wyjaśnienia ewolucyjne jako naciągane lub niepełne, po czym wnioskują, że w takim razie pozostaje tylko jedno wyjaśnienie - właśnie ich wersja. ${ }^{120}$

Nie rozumieją też, na czym polega uprawianie nauki, oraz są leniwi (zamiast szukać wyjaśnień naturalistycznych, idą łatwiejszą drogą i odwołują się do projektanta wszędzie tam, gdzie jest to dla nich wygodne) i nie szukają trafnych rozwiązań, ponieważ

nie dostrzegają przytłaczających świadectw, z których jednoznacznie wynika, że istoty żyjące na Ziemi zmieniały się z upływem czasu. ${ }^{121}$

Zauważa się także z nieukrywanym smutkiem:

cóż z tego, że [my, ewolucjoniści] mamy słuszne poglądy na wszystko, skoro istnieje znaczna grupa ludzi, którzy ich po prostu nie chcą słuchać? ${ }^{122}$

O nienaukowym statusie tej teorii rozstrzyga się również za pomocą procedur demokratycznych:

profesorowie San Francisco State University przyjęli, stosunkiem głosów 27 do 5, rezolucję głoszącą, iż ,nie istnieje żadne świadectwo naukowe popierające koncepcję inteligentnego projektu” i [...] dlatego „pogląd, iż istnieje inteligentny projekt, nie ma charakteru naukowego". ${ }^{12}$

\footnotetext{
${ }^{118}$ Marcin RoткIEwicz, „Barbarzyńcy u bram”, Polityka 26 stycznia 2008, nr 4 (2638), s. 92, https://tiny.pl/g8zfm (26.12.2018).

${ }^{119}$ Por. Woodward, „Istota sporu...”, s. 10.

${ }^{120}$ RenNIE, „15 odpowiedzi...”, s. 72.

${ }^{121}$ Por. Woodward, „Istota sporu...”, s. 11. Por. też Dawkins, Bóg urojony..., s. 184; SAGan, „Spór o możliwość...”, s. 107.

${ }^{122}$ Jerzy Kowalski-Glikman, „Bezradność postępowego inteligenta”, Świat Nauki 2008, nr 2 (198), s. 85 [84-85], https://tiny.pl/g2s2g (26.12.2018).
} 
Przychylnie nastawieni do inteligentnego projektu twierdzą, że kontrowersje wokół teorii ID są następstwem przede wszystkim ,jej filozoficznego i teologicznego wydźwięku": ${ }^{124}$

Istnieje [bowiem] możliwość potraktowania teorii inteligentnego projektu jako teorii naukowej - jeśli nawet nie w jej obecnej postaci, to może w jakiejś innej, którą być może udałoby się sformułować w przyszłości. ${ }^{125}$

[Dlatego też] każdy system poglądów, który stawia sobie za zadanie zaprzeczenie lub zaproponowanie wyjaśnienia pomijającego przytłaczające dowody na rzecz projektu widocznego w świecie istot żywych jest ideologią, a nie nauką. ${ }^{126}$

Nakreślone powyżej wojny światopoglądowo-ideologiczne doczekały się następującej oceny:

żyjemy w przełomowym okresie, w okresie rewolucji, ale rewolucji pełzającej, rozciągniętej na całe dziesięciolecia (choć od trzydziestu lat stale przyspieszającej) i przez to słabo dostrzeganej i uświadamianej, rewolucji, która od stu pięćdziesięciu lat zmienia w decydujący sposób charakter naszej cywilizacji, prowadzi do cywilizacji postchrześcijańskiej, gdyż [...] darwinizm jak uniwersalny kwas rozpuszcza wszystko, nawet moralność i religię.

\footnotetext{
${ }^{123}$ Phillip E. Johnson, „Głośna «herezja» w świątyni Darwina”, przeł. Kazimierz Jodkowski, w: JodKowsKi, Metodologiczne aspekty..., s. 474 [473-481], https://tiny.pl/tqdzv (26.12.2018).

${ }^{124}$ Por. Michael J. Behe, „Nieredukowalna złożoność: problem dla ewolucjonizmu darwinowskiego", przeł. Dariusz Sagan, Filozoficzne Aspekty Genezy 2005/2006, t. 2/3, s. 73 [67-96], https://tiny.pl/qzq8n (26.12.2018).

${ }^{125}$ SAGAn, „Spór o możliwość...”, s. 109.

${ }^{126}$ Christoph SchönBorn, „Odnajdywanie zamysłu w przyrodzie”, przeł. Piotr Lenartowicz SJ, Filozoficzne Aspekty Genezy 2005/2006, t. 2/3, s. 19 [19-22], https://tiny.pl/xhhdk (25.12. 2018). Por. też Dariusz SAGan, „Kardynał Schönborn a stanowisko Kościoła katolickiego wobec sporu kreacjonizmu z ewolucjonizmem”, Filozofia Nauki 2006, nr 1 (53), s. 109, 118 [107-118], https://tiny.pl/g2vg9 (25.12.2018).

${ }^{127}$ JoDKowski, „Twarde jądro...”, s. 112. Por. też JodKowski, „Dlaczego ewolucjonizm...”, s. 70; Piotr Bylica, „Bóg luk a granice nauki”, Referat wygłoszony na III Filozoficznym Forum Młodych, Lublin 2004, s. 1 [1-12], https://tiny.pl/hdqgd (26.12.2018); Piotr ByLICA, „Kazimierza Jodkowskiego koncepcja epistemicznych układów odniesienia a teizm naturalistyczny Johna Polkinghorne'a”, w: Bylica, Kilian, Piotrowski i Sagan (red.), Filozofia - nauka - religia..., s. 197 [191-211], https://tiny.pl/tqd37 (26.12.2018); Grzegorz MaLEC, „Teologiczne dylematy Karola Darwina", Roczniki Filozoficzne 2012, t. 60, nr 1, s. 81 [67-85], https://tiny.pl/xhnkp (26.12. 2018); William A. Dемвsк and Jonathan Wiтt, Intelligent Design Uncensored: An Easy-to-Understand Guide to the Controversy, InterVarsity Press, Downers Grove, Illinois 2010, s. 23-24;
} 
Opinia ta nie jest gołosłowna:

My, uczeni, powinniśmy zrobić wszystko, co tylko możliwe, aby osłabić uścisk religii. I to może ostatecznie okazać się naszym największym wkładem do cywilizacji. ${ }^{28}$

Albowiem

cywilizacja jest w stanie wojny. Jest to wojna z religijną bigoterią. ${ }^{129}$

\section{Teistyczno-naturalistyczny EUO $\mathrm{i}$ jego problemy}

Próbą obrony cywilizacji chrześcijańskiej ma być teizm naturalistyczny. ${ }^{130}$ Jest on specyficzną odmianą EUO. Zdefiniowanie tego EUO i jego twardego jądra poprzedzone zostanie uwagami pozwalającymi na zrozumienie tej specyfiki.

Naturalistyczne i antynaturalistyczne EUO w zamierzeniu tworzyć mają najogólniejsze, poznawcze ramy dla uprawiania nauki. ${ }^{131}$ Naturalistyczny teizm również tworzy taką ramę. Tworzy też inną, sui generis światopoglądową ramę jej uprawiania. Oczywiście, o czym świadczą choćby rozważania przeprowadzone w poprzednim paragrafie, u podstaw wcześniej omówionych EUO również tkwią określone światopoglądy, które pewnym ludzkim działaniom nadają

John G. West, „Darwin's Corrosive Idea: The Impact of Evolution on Attitudes About Faith, Ethics, and Human Uniqueness", Discovery Institute's Center for Science and Culture 2016, s. 3 [1-19], https://tiny.pl/tqd3r (26.12.2018); Dominic Sтатнам, „Darwin's Corrosive Idea”, Creation Ministries International 19 September 2017, https://tiny.pl/tqd3d (26.12.2018).

${ }^{128}$ Wypowiedź Stevena Weinberga przytaczana za: Johnson, „A Free-for-All...”.

${ }^{129}$ Wypowiedź Richarda Dawkinsa przytaczana za: JoDkowski, Metodologiczne aspekty..., s. 200. Na stronach 199-201 wspomnianej monografii odnaleźć można więcej tego typu wypowiedzi. Por. też Kazimierz JodKowski, „Ślepy zegarmistrz”, w: JodKowsKi, Metodologiczne aspekty..., s. 367 [351-369], https://tiny.pl/tqd3f (26.12.2018).

${ }^{130}$ Używa się też zamiennie innych nazw: „naturalizm chrześcijański”, „teizm naturalistyczny” i ,naturalizm teistyczny” (por. Piotr ByLICA, „NDE a empiryczność argumentów na rzecz tezy o dualizmie duszy i ciała w kontekście relacji nauki i religii”, w: Wiesław Dyk (red.), Sozologia systemowa. Tom VI. Noosfera. Człowiek i jego środowisko w aspekcie przyrodniczym, filozoficznym i teologicznym, Wydawnictwo Naukowe Uniwersytetu Szczecińskiego, Szczecin 2014, s. 93 [91-132], https://tiny.pl/tqd3p [26.12.2018]).

${ }^{131}$ Por. np. KiLIan, „Czym są epistemiczne...”, s. 192-194. 
sens, innym zaś tego sensu odmawiają. Jednak naturalistyczny teizm jest takim EUO, który ma przede wszystkim zażegnać

kryzys wiary wśród ludzi wykształconych, w szczególności naukowców, będący wynikiem niezgodności tradycyjnego teistycznego oraz współczesnego naukowego opisu świata ${ }^{132}$

i wiarę tę uczonym przywrócić. Kryzys ten łagodzony jest

przez istotną i ważną religijnie zmianę treści wiary: Bóg nie działa w przyrodzie w specjalny, rozpoznawalny empirycznie sposób. ${ }^{133}$

Zmianę tę obrazuje na przykład taka wypowiedź jednego ze zwolenników teizmu naturalistycznego:

Bóg nie działa na świat jakimiś nadzwyczajnymi interwencjami, lecz zawsze poprzez naturalny bieg świata. Jego działanie nie ujawnia się w naturalnym biegu świata nie dlatego, że Jego działania tam nie ma, ale dlatego, że cały naturalny bieg świata jest jego działaniem. ${ }^{134}$

Zaś efektem tej zmiany ma być pogodzenie obrazu świata współczesnego przyrodoznawstwa $\mathrm{z}$ teizmem chrześcijańskim. ${ }^{135}$ Zmiana, o której tu mowa, bywa waloryzowana pozytywnie przez przyrodników:

\footnotetext{
${ }^{132}$ Piotr Bylica, „Główne założenia i problemy teizmu naturalistycznego w sprawie relacji sfery nadprzyrodzonej i świata przyrodniczego", w: Wiesław Dүк (red.), Sozologia systemowa. Tom IV. Biosfera. Czlowiek i jego środowisko $w$ aspekcie przyrodniczym, filozoficznym i teologicznym, Wydawnictwo Naukowe Uniwersytetu Szczecińskiego, Szczecin 2012, s. 88 [55-95], https://tiny.pl/q3m1d (26.12.2018) [wyróżnienie dodane]. Por. też BYLICA, „Kazimierza Jodkowskiego...", s. 210; ByLica, Wspólczesny teizm..., s. 152-153.

${ }^{133}$ Fragment korespondencji autora z Piotrem Bylicą [wyróżnienie dodane].

${ }^{134}$ Michał Heller, „Chrześcijański naturalizm”, Roczniki Filozoficzne 2003, t. 51, nr 3, s. 47 [41-58], https://tiny.pl/tq2q2 (26.12.2018).

${ }^{135}$ Por. Jodkowski, „Dlaczego ewolucjonizm...”, s. 69; Piotr Bylica, Krzysztof J. Kilian i Dariusz Sagan, „Wstęp”, w: Bylica, Kilian, Piotrowski i Sagan (red.), Filozofia - nauka - religia..., s. 25 [11-33], https://tiny.pl/tqd3k (26.12.2018); Piotr BylicA, „Mark Harris as a Naturalistic Theist: The Perspective of the Model of Levels of Analysis", Filozoficzne Aspekty Genezy 2015, t. 12, s. 8 [7-36], https://tiny.pl/tqd38 (26.12.2018); Piotr ByLICA, „Nauka światopoglądowo neutralna?", Fronda 2012, nr 63, s. 75-76 [67-80], https://tiny.pl/gkfxr (26.12.2018); BYLICA, „Główne założenia...”, s. 64, 55; ByLica, „Kazimierza Jodkowskiego...”, s. 192.
} 
nowe interpretacje nauk Kościoła wydają się być koniecznością, gdyż grozi im alternatywa zamknięcia się świata religii w izolowanym od współczesności bajkowym skansenie. ${ }^{136}$

Sedno zgody między wizjami teistyczną i naturalistyczną wyrażono tak:

Bóg prowadzi ewoluującą przyrodę ku swym planom. ${ }^{137}$

Ma to być, w zamierzeniu twórców tego podejścia, opcja zarazem naturalistyczna i teistyczna. Zakazuje ona uznawania wyjaśnień antynaturalistycznych:

W nauce nigdy nie wolno rezygnować z wyjaśnienia jakiegoś „,materialnego zjawiska” przy pomocy innego „materialnego zjawiska”. Rezygnacja z takiego wyjaśnienia i powołanie się na wyjaśnienie „wychodzące poza świat materialny” byłoby zablokowaniem dalszego postępu, a więc sprzeniewierzeniem się naukowej metodzie. ${ }^{138}$

Zakazuje zatem wyjaśnień nadnaturalistycznych:

celowa organizacja istot żywych mogła powstać wskutek działania przyrodniczego procesu — selekcji naturalnej — i [...] w ogóle nie trzeba powoływać się na Stwórcę lub inną zewnętrzną przyczynę. ${ }^{139}$

Zakazuje też wyjaśnień artyficjalistycznych:

Jeżeli za naczelną zasadę metodologiczną nauki przyjmuje się naturalizm, czyli postulat thumaczenia wszystkiego tylko przez przyczyny naturalne, to [...] Inteligentnego Projektanta [...] eliminuje się nie na mocy jakichś argumentów, lecz na mocy założenia, a takie postępowanie jest nienaukowe. ${ }^{140}$

\footnotetext{
${ }^{136}$ Wypowiedź Jerzego Lukierskiego przytaczam za: WoJnar, „Czy nauka zastąpi...”, s. 93.

${ }^{137}$ SŁOмка, „Powrót inteligentnego...”, s. 342.

${ }^{138}$ Michał Heller, Sens życia i sens Wszechświata. Studia z teologii wspólczesnej, Biblos, Tarnów 2002, s. 44. Por. też ByLICA, „Nauka światopoglądowo...”, s. 75.

${ }^{139}$ Francisco J. Ayala, „Darwin's Revolution”, w: John H. Campbell and J.W. Schopf (eds.), Creative Evolution!?, Jones and Bartlett, New York 1994, s. 4-5 [1-18] (cyt. za: Stephen C. MEYER, „Demarkacja nauki i religii”, przeł. Joanna Popek, Filozoficzne Aspekty Genezy 2009/2010, t. 6/7, s. 181 [177-196], https://tiny.pl/xh8jj [26.12.2018]).

${ }^{140}$ Michał Heller, ,Nie za bardzo inteligentny projekt”, Copernicus Center 24 grudnia 2014, https://tiny.pl/gzj65 (26.12.2018).
} 
Nakazuje zatem przyjmowanie wyłącznie naturalistycznych wyjaśnień dla zjawisk przyrodniczych i odnajdywanie stwórczej aktywności Boga jedynie w sferze pozaempirycznej. ${ }^{141}$ Naturalistyczni teiści

kierowani naukową solidarnością [ze swoimi kolegami-ateistami] uważają, że naukę najlepiej uprawiać, wykluczając z niej projekt ${ }^{142}$

i

przyjmują na wiarę, że za ewolucją stoi Bóg, zaprzeczają jednak, by rozum i nauka mogły odkryć jakiekolwiek świadectwo empiryczne Boskiego planu stwórczego. ${ }^{143}$

Założenie metodologicznego naturalizmu opatrywane jest tezą, że nie stanowi ono zagrożenia dla religii, gdyż, ze względu na swój metodologiczny charakter, nie wyklucza istnienia Boga ${ }^{144} \mathrm{i}$, jako takie

Zauważono jednak, że ten wymóg naturalizmu metodologicznego, który zakazuje wyjaśnień artyficjalistycznych, staje się warunkiem nieadekwatnym uprawiania nauki, bo niezgodnym z tym, co na co dzień robi się w nauce. Wiedzie bowiem do uznania za nienaukowe tych dyscyplin, którym powszechnie nie odmawia się statusu naukowości. Istnieją dyscypliny (na przykład archeologia) i przedsięwzięcia naukowe (na przykład program SETI), które dopuszczają wyjaśnienia artyficjalistyczne (archeologowie niejednokrotnie stwierdzają, że odkryte przez nich przedmioty są wytworami istot inteligentnych, zaś w ramach SETI poszukiwane są ślady pozaziemskiej inteligencji), a nikt im nie odmawia pretensji do naukowości (por. np. Kazimierz JoDKowski, „Kreacjonizm a naturalizm nauk przyrodniczych”, Annales Universitatis Mariae CurieSkłodowska, Sectio I, Lublin-Polonia 1996/1997, vol. 21-22, s. 19-20 [11-26], https://tiny.pl/gkf x4 [26.12.2018]; SAGAN, „Naturalizm metodologiczny — konieczny...”, s. 86).

${ }^{141}$ Por. Bylıca, „Główne założenia...”, s. 70-71; Jodkowski, „Wstęp do teorii...”, s. 25.

${ }^{142}$ William A. DemBsкi, „Powrót projektu do nauk przyrodniczych”, przeł. Dariusz Sagan, $\mathrm{Na}$ Początku... 2004, nr 9-10 (185-186), s. 323 [323-342], https://tiny.pl/thmgz (26.12.2018).

${ }^{143}$ RYLAND, ,«Teoria inteligentnego projektu»...”, s. 414.

${ }^{144}$ Por. Wiesław M. MACEK, Teologia nauki według księdza Michała Hellera, Wydawnictwo Uniwersytetu Kardynała Stefana Wyszyńskiego, Warszawa 2010, s. 74; Józef ŻYciŃsKI, „Naturalizm ontologiczny a rola superweniencji w ewolucji biologicznej”, Roczniki Filozoficzne 2003, t. 51, z. 3, s. 7-8 [7-18], https://tiny.pl/tqfhz (26.12.2018); Wojciech Kотоwicz, „Józefa Życińskiego meta-przedmiotowe ujęcie relacji między nauką a religią”, Roczniki Filozoficzne 2012, t. 60, z. 4, s. 251-253 [249-260], https://tiny.pl/tqfh3 (26.12.2018). Por. też ByLicA, „Główne założenia...”, s. 62-63; Piotr BYLICA, „Zarys modelu poziomów analizy w badaniach relacji nauki i religii”, Filozoficzne Aspekty Genezy 2012, t. 9, s. 235-236 [221-253], https://tiny.pl/xhzml (26.12. 2018); SAGAN, „Naturalizm metodologiczny — konieczny...”, s. 74; SAGAN, „Kardynał Schönborn...", s. 112. 
nie stanowi [...] żadnego zagrożenia dla prawdy chrześcijańskiej. ${ }^{145}$

Metoda naukowa nie nakazuje [bowiem] zakładać, iż Boga nie ma, lecz żąda, by prowadząc badanie naukowe zachować metodologiczną neutralność wobec problemu Jego istnienia lub nieistnienia. ${ }^{146}$

Zaś naturalizm przyjmowany jest tu wyłącznie z tego powodu,

że w historii nauki okazał się niezwykle skuteczny, a więc ze względów czysto pragmatycznych. ${ }^{147}$

Szczególnym szacunkiem obdarza się w ramach tego podejścia gradualistyczny ewolucjonizm. Nie tylko przekonuje się, iż

konflikt między Darwinowską teorią doboru naturalnego a chrześcijańską wizją przyrody stanowi w dużym stopniu wynik fobii rozwiniętych w początkach naszego stulecia przez fundamentalizm. ${ }^{148}$

${ }^{145}$ Paul DE VRIES, „Naturalizm w naukach przyrodniczych. Perspektywa chrześcijańska”, przeł. Radosław Plato, Filozoficzne Aspekty Genezy 2011, t. 8, s. 123 [121-135], https://tiny.pl/xh $8 \mathrm{gc}(27.12 .2018)$.

${ }^{146}$ Heller, Sens życia..., s. 45. Por. też komentarz do tej tezy: Bylica, „Główne założenia...”, s. 62-63. Por. również BylicA, „Mark Harris...”, s. 14-16; DE VRIES, „Naturalizm w naukach...", s. 131-135; Eugenie C. Sсотт, Evolution vs. Creationism: An Introduction, 2nd ed., Greenwood Press, Westport, Connecticut, London 2009, s. 56-57; James Porter Moreland and William Lane CRAIG, Philosophical Foundations for a Christian Worldview, InterVarsity Press, Downers Grove 2003, s. 358-359.

${ }^{147}$ Heller, ,Nie za bardzo...”.

${ }^{148}$ Józef Życiński, „Ewolucyjna wizja przyrody a XIX-wieczny teizm”, Studia Philosophiae Christianae 1996, t. 32, nr 1, s. 73 [73-89], https://tiny.pl/tqfl2 (27.12.2018).

Przywoływany autor utrzymywał, że Darwin w momencie publikowania On the Origin of Species wierzył w „Boskiego Stwórcę, który kieruje zmiennością gatunków i całym rozwojem przyrody” (Józef ŻyciŃski, „U źródeł biologii niearystotelesowskiej”, w: Michał Heller i Józef ŻYCiŃSKI, Dylematy ewolucji, Polskie Towarzystwo Teologiczne, Kraków 1990, s. 38 [9-39]). W sprawie błędności tego przekonania por. np. JoDKowski, „Poglądy teologiczne...”, s. 66-68, 7071; Grzegorz Malec, „Kiedy Darwin stracił wiarę w Boga?”, Diametros 2016, nr 48, s. 44-50 [3854], https://tiny.pl/tqf45 (27.12.2018); Grzegorz MALEC, „Erozja teizmu Darwina, czyli wpływ podróży na okręcie HMS Beagle na poglądy teologiczne angielskiego przyrodnika”, w: Krzysztof BAŁĘKOWSKI i Kamil MACIĄG (red.), Wybrane zagadnienia z filozofii języka i religii, Fundacja na rzecz promocji nauki i rozwoju TYGIEL, Lublin 2015, s. 110-120, https://tiny.pl/g7krx (27.12. 2018); Grzegorz MaLEC, „Charles Darwin and Lady Hope - The Legend Still Alive”, Hybris 
Twierdzi się również, że

ewolucyjna wizja przyrody znacznie lepiej wyraża chrześcijańską doktrynę o stworzeniu i immanencji Boga, niż czyniła to biologia przed-Darwinowska. ${ }^{149}$

Ta ostatnia sugerowała, że Bóg stworzył gotowy świat, zaś Darwinowska prowadzić ma do przekonania, w myśl którego Bóg stworzył świat, który sam się tworzy: ${ }^{150}$

W tym sensie ewolucja nie tylko nie stoi w opozycji wobec stworzenia, lecz razem z nim daje obraz syntetyczny. ${ }^{151}$

Dlatego zwolennicy tego ujęcia mówią o „kreacjonizmie ewolucyjnym” ${ }^{152}$

2015, nr 29, s. 134 [126-149], https://tiny.pl/tqf46 (27.12.2018). Por. też: Brooke, „Karol Darwin...”, s. 62; Johnson, „Czy darwinizm...”, s. 79.

${ }^{149}$ Józef ŻYCIŃSKI, Bóg i ewolucja. Podstawowe pytania ewolucjonizmu chrześcijańskiego, Prace Wydziału Filozoficznego, t. 89, Towarzystwo Naukowe KUL, Lublin 2002, s. 24.

${ }^{150}$ Por. ByLica, „Główne założenia...”, s. 67-69.

${ }^{151}$ Michał Heller, Nowa fizyka i nowa teologia, Biblos, Tarnów 1992, s. 120. Por. komentarz do tego typu argumentacji: JoDKowsKi, „Eskapizm teologii...”, s. 284; Michał CHABerek OP, „Św. Tomasz z Akwinu a ewolucjonizm. Polemika z tezami Piotra Lichacza OP i Williama E. Carrolla”, Filozoficzne Aspekty Genezy 2012, t. 9, s. 37-39 [33-52], https://tiny.pl/xhnqc (27. 12.2018). Por. też John BrookEs, „Science and Religion: Lessons from History?”, Science 1998, vol. 282, no. 5396, s. 1986 [1985-1986], https://tiny.pl/tqfnq (27.12.2018); PenNock, „Creationism and Intelligent...., s. 144.

${ }^{152}$ Por. Michał Heller, Usprawiedliwienie Wszechświata, Społeczny Instytut Wydawniczy Znak, Kraków 1984, s. 176; ŻYCIŃSKI, „Ewolucyjna wizja...”, s. 87; МАСЕK, Teologia nauki..., s. 121; Karolina Rożko, „Teologia naturalna Stokesa”, Filozoficzne Aspekty Genezy 2009/2010, t. 6/7, s. 221-222 [213-226], https://tiny.pl/tqfng (27.12.2018); SAGAN, ,Teoria inteligentnego projektu a kreacjonizm...", s. 137.

W myśl klasyfikacji stanowisk kreacjonistycznych przeprowadzonych przez Eugenie Scott i Donalda Wise'a odróżniać należy kreacjonizm ewolucyjny od teistycznego ewolucjonizmu. Wspólną cechą obydwu stanowisk jest przekonanie, iż ewolucja jest sposobem działania Boga. Różnić się mają tym, że ci pierwsi funkcjonują w ramach konserwatywnych ewangelikalnych chrześcijan, zaś ci drudzy w ramach liberalnych chrześcijan (na przykład katolików) (por. JoDKowski, „Klasyfikacja stanowisk...”, s. 254; Kazimierz JoDкоwskI, Spór ewolucjonizmu z kreacjonizmem. Podstawowe pojęcia i poglądy, Biblioteka Filozoficznych Aspektów Genezy, t. 1, Wydawnictwo MEGAS, Warszawa 2007, s. 164-167, https://tiny.pl/qzq8j [27.12.2018]). Różnica ta, jak widać po nomenklaturze Hellera, jest nieistotna i „polega jedynie na użyciu innych słów” tworzących obydwie nazwy (por. JoDKOwSKI, „Klasyfikacja stanowisk...”, s. 256). 
lub o „ewolucji teistycznej”. ${ }^{153}$ (Taką postawę nadmiernego zaangażowania filozofów i teologów chrześcijańskich po stronie darwinizmu nazwano „ukąszeniem darwinowskim”. ${ }^{154}$ ) Pojawiają się też określenia „teistyczny ewolucjonizm naturalistyczny”, ,teistyczny naturalizm”, ${ }^{155}$ „religijny naturalizm” ${ }^{156} \mathrm{i}$,naturalizm antynadnaturalistyczny". ${ }^{157}$

Jest to teizm - świat został stworzony przez Boga, On nadał mu prawa i podtrzymuje go w istnieniu — któremu nadaje się szczególny, bo monistyczny wymiar. ${ }^{158}$ Zaś

\footnotetext{
${ }^{153}$ Por. Robert A. Delfino, „Naturalizm metodologiczny i ewolucja”, przeł. Rafał Lizut, w: Piotr JARoszyŃSKI (red.), Ewolucjonizm czy kreacjonizm, Przyszłość Cywilizacji Zachodu, Fundacja „Lubelska Szkoła Filozofii Chrześcijańskiej”, Lublin 2008, s. 140 [137-156], https://tiny.pl/gz j7b (27.12.2018).

${ }^{154}$ Por. Jodkowski, „Eskapizm teologii...”, s. 274-274.

${ }^{155}$ Por. SAGAN, „Teoria inteligentnego projektu a ewolucjonizm...”, s. 91

${ }^{156}$ Por. Ursula Goodenough, „Who Is a Religious Naturalist?”, Theology and Science 2017, vol. 15, no.3, s. 231 [231-234]; Ursula Goodenough, „Are You a Religious Naturalist Without Knowing It?", National Public Radio. Cosmos and Culture. Commentary on Science and Society 29 January 2010, https://tiny.pl/tqfkx (27.12.2018).
}

Nazwę ,antropocentryczny układ odniesienia”, za pomocą której można charakteryzować podejścia kreacjonistyczne (por. w tej sprawie s. 6 niniejszego tekstu), da się również odnieść, choć z pewnymi zastrzeżeniami, do naturalistycznego teizmu. Niektórzy jego zwolennicy utrzymują przekonanie o subtelnym zestrojeniu człowieka i wszechświata:

Niewielka zmiana pewnych własności wszechświata uniemożliwiłaby nasze zaistnienie. $\mathrm{Na}$ przykład gdyby prędkość eksplozji Wielkiego Wybuchu była odrobinę inna, niż była, życie nie mogłoby powstać. Nieco mniejsza prędkość pierwotnej ekspansji spowodowałaby ponowne zapadnięcie się wszechświata do końcowej osobliwości, czyli końcowego anty-Wielkiego-Wybuchu, w ciągu bardzo krótkiego czasu (w pewnych warunkach nawet w ciągu ułamka sekundy). Żadna twórcza ewolucja nie zdążyłaby się wtedy zawiązać. Gdyby natomiast prędkość pierwotnej ekspansji była trochę większa od tej, jaka rzeczywiście zaistniała, ekspansja wszechświata następowałaby tak szybko, że wygładzałaby wszystkie nierówności w rozkładzie materii, nie dopuszczając do powstania galaktyk, gwiazd i planet.

Wypowiedź Michała Hellera w: Monika Florek-Moskal, „Wszechświat jest twórczy, choć nieprzewidywalny. Rozmowa z ks. prof. Michałem Hellerem, kosmologiem, filozofem, fizykiem i teologiem, laureatem Nagrody Templetona (2008)", Wprost 2010, nr 1/2, https://tiny.pl/tqfkg (27.12.2018).

Jednak w tej samej rozmowie, na pytanie o to, czy to subtelne zestrojenie rozumieć należy tak, że „ewolucja wszechświata była skierowana na nasze zaistnienie?”, Heller odpowiedział: 
kwintesencją [tradycyjnego] teizmu jest uznanie istnienia Boga [...], osobowego $\mathrm{i}$ transcendentnego, $[\ldots]$ odrębnego i zewnętrznego w stosunku do świata (w przeciwieństwie do panteizmu) i stale kierującego światem po jego stworzeniu (w przeciwieństwie do deizmu) [czyli dualizm i interwencjonizm]. ${ }^{159}$

Dualizm wyrażany jest przekonaniem o podziale rzeczywistości na sfery przyrodzoną i nadprzyrodzoną — „widzialną i niewidzialną”, zgodnie z nicejsko-konstantynopolitańskim wyznaniem wiary. Sferę przyrodzoną tworzą wszystkie wytwory człowieka oraz byty i procesy świata przyrody. Na sferę nadprzyrodzoną składają się Bóg-Stwórca oraz niższe byty duchowe, czyli anio-

Przestrzegałbym przed takim twierdzeniem. Kopernik już kiedyś usunął człowieka ze środka wszechświata. Nie róbmy teraz z człowieka celu kosmicznej ewolucji.

W opinii Bylicy teizm naturalistyczny jest zerwaniem z myśleniem antropocentrycznym. Teizm ten jest myśleniem w kategoriach ekoteologicznych (każdy gatunek ma szczególne znaczenie dla Boga, w następstwie czego człowiek nie jest gatunkiem wyróżnionym) (por. Piotr BYLICA, „Darwinizm i koncepcja wieloświata a religijne wyjaśnienie racjonalnego porządku i poznawalności przyrody", Zagadnienia Naukoznawstwa 2012, nr 3 (193) s. 192 [185-204], https://tiny.pl/x hnlq [27.12.2018]; Piotr ByLICA, „Wątki antyantropocentryzmu i ekologizmu w tekstach teistów naturalistycznych - z punktu widzenia modelu poziomów analizy", w: Wiesław Dyк, Wiesław SkrzypcZAK i Tadeusz Dyk (red.), Sozologia systemowa. Tom VIII. Kosmosfera. Żywa planeta w oceanie Wszechświata: Czlowiek i jego środowisko w aspekcie przyrodniczym, filozoficznym i teologicznym, Wydawnictwo Naukowe Uniwersytetu Szczecińskiego, Szczecin 2016, s. 22 [11-31]; ByLICA, Współczesny teizm..., s. 168-169).

W sprawie innych możliwych scenariuszy wyjaśniających to „zestrojenie” por. Ernan McMuluin, „Odmiany naturalizmu metodologicznego”, przeł. Ewelina Topolska, Filozoficzne Aspekty Genezy 2012, t. 9, s. 113-114 [109-129], https://tiny.pl/xh8pf (27.12.2018); Alan P. Lightman, „Przypadkowy Wszechświat: kryzys wiary w nauce”, przeł. Dariusz Sagan, Filozoficzne Aspekty Genezy 2012, t. 9, s. 259-261, 263-265 [255-267], https://tiny.pl/xh8jq (27.12.2018); Randy IsAAC, „Od luk w wiedzy do wniosku o istnieniu Boga”, przeł. Małgorzata Gazda, Filozoficzne Aspekty Genezy 2012, t. 9, s. 197-198 [187-198], https://tiny.pl/xhzmp (27.12.2018); Paul DAvIES, „Fizyka i umysł Boga. Przemówienie na uroczystości wręczenia Nagrody Templetona”, przeł. Joanna Popek, Filozoficzne Aspekty Genezy 2011, t. 8, s. 16-18 [7-21], https://tiny.pl/xhnlk (27.12.2018); Thaxton, „Nowy argument...”, s. 157; Delfino, „Naturalizm metodologiczny...”, s. 149-153.

${ }^{157}$ Por. William A. DemBski, „Odmiany naturalizmu. Czy któraś forma naturalizmu jest zgodna z teorią inteligentnego projektu?”, przeł. Dariusz Sagan, Na Początku ... 2005, nr 1-2, s. $48-49$ [45-54], https://tiny.pl/xhkg8 (27.12.2018).

${ }^{158}$ Por. Plantinga, „Naturalizm metodologiczny...”, s. 75-77; Heller, „Chrześcijański naturalizm...", s. 47.

${ }^{159}$ Zachariasz Łүко, Zarys filozofii chrześcijańskiej, Chrześcijańska Akademia Teologiczna, Warszawa 1995, s. 222. 
łowie i aniołowie upadli. Interwencjonizm wyraża się w przekonaniu, w myśl którego w różnych okolicznościach, w sposób specjalny sfera nadprzyrodzona celowo oddziałuje na świat przyrody, ${ }^{160}$ zaś te oddziaływania, zgodnie z tradycyjną teologią naturalną, są w przyrodzie empirycznie wykrywalne. ${ }^{161}$

Ten szczególny wymiar nowego teizmu, opierającego się na nowej teologii naturalnej, ${ }^{162}$ widoczny jest też w ,umiejętnym czytaniu” ksiąg Pisma Świętego i przyrody, ${ }^{163}$ które, najogólniej rzecz biorąc, jest zakazem literalnego rozumienia przede wszystkim tych partii Biblii, które mówią o stworzeniu świata:

Wizja świata religii różni się od wizji ukazywanej przez nauki przyrodnicze; obydwie wizje trzeba uzgodnić. I zgoda polega na tym, że tekst biblijny traktujemy jak hymn autora biblijnego ku czci Stwórcy, informujemy o tym, że Bóg stworzył świat i że dzieło stworzenia jest dobre. ${ }^{164}$

Nie wolno thumaczyć Pisma Świętego dosłownie, bo Pismo Święte nie jest przekazem, rejestracją danych empirycznych.

Przyznaje się, iż

teologiczna koncepcja stworzenia (jak żadna inna doktryna teologiczna) ściśle zależy od stanu nauk w danej epoce ${ }^{166}$

oraz że

interpretacja prawd wiary nie może być niezgodna z tym, co zostało ustalone na dro-

\footnotetext{
${ }^{160}$ Por. Bylica, „Główne założenia...”, s. 70-71; Piotr Bylica, „Darwin o celowości w przyrodzie", Kwartalnik Historii Nauki i Techniki 2008, nr 3-4, s. 265 [259-273], https://tiny.pl/q3m1c (27.12.2018).

${ }^{161}$ Por. BYLICA, „Kazimierza Jodkowskiego...”, s. 210; BYLICA, „Darwinizm i koncepcja...”, s. 187; ByLica, Wspólczesny teizm..., s. 152-153.

${ }^{162}$ Por. Bylica, Wspólczesny teizm..., s. 137; Bylica, „Darwinizm i koncepcja...”, s. 191.

${ }^{163}$ Por. Котошісz, ,Józefa Życińskiego...”, s. 253-255.

${ }^{164}$ Wypowiedź Józefa Życińskiego w: Józef ŻYciński i Marek HetмaŃski, „Religijny a naukowy obraz świata (debata)", Annales Universitatis Mariae Curie-Skłodowska 2012, sec. I, vol. 37, nr 1, s. 56 [53-76], https://tiny.pl/tqfkl (27.12.2018).

${ }^{165}$ Wypowiedź Józefa Życińskiego w: ŻYciński i Hetmański, „Religijny a naukowy...”, s. 68.

${ }^{166}$ Heller, Nowa fizyka..., s. 122.
} 
dze dobrze potwierdzonych analiz o charakterze naukowym. ${ }^{167}$

Co, jak zauważono, prowadzi do

stałe[go] dopasowywani[a] treści teologii do treści nauki, do podporządkowania sfery religii sferze nauki. ${ }^{168}$

\section{Odbywa się to}

kosztem [...] znacznego przeinterpretowania podstawowych składników tradycyjnej wiary chrześcijańskiej. ${ }^{16}$

Przyjęcie teistycznego ewolucjonizmu [...] oznacza najczęściej uznanie zupełnie materialistycznego wyjaśnienia początków świata, gatunków, człowieka, a jednocześnie odrzucenie słusznego autorytetu Pisma Świętego. ${ }^{17}$

Przeinterpretowanie to jest dobrze widoczne w następujących dwóch wypowiedziach. Pierwsza z nich to opinia astronoma Obserwatorium Watykańskiego, jezuity George'a V. Coyne'a:

Proces ciągłej ewolucji, zwany przez naukowców wzrostem złożoności chemicznej, ma pewną wewnętrzną, naturalną kierunkowość, która przejawia się w tym, że im bardziej organizm staje się złożony, tym bardziej zdeterminowana jest jego przyszłość. Nie oznacza to koniecznie, że musi istnieć osoba kierująca tym procesem, ani że ów proces jest z konieczności „niekierowanym, nieplanowanym procesem przypadkowych zmian i naturalnej selekcji” [...]. Za kierunkowość procesu ewolucji odpowiedzialna jest właśnie płodność Wszechświata oraz współdziałanie w nim przypadku i konieczności. Tyle ma do powiedzenia nauka. Człowiek wierzący zapytuje teraz, gdzie w tym scenariuszu naukowym miejsce dla Boga Stwórcy? [...] W swojej nieskończonej wolności Bóg nieustannie stwarza świat odzwierciedlający tę wolność na wszystkich poziomach procesu ewolucyjnego, zmierzającego do coraz większej złożo-

\footnotetext{
${ }^{167}$ PABIAN, „Nauka i wiara...”.

${ }^{168}$ Jodkowski, „Eskapizm teologii...”, s. 263. Por. też ByLICA, „Główne założenia...”, s. 74.

${ }^{169}$ ByLicA, „Główne założenia...”, s. 56-57.

${ }^{170}$ Wypowiedź Michała Chaberka w: Tomasz Rowiński, „Dlaczego warto nauczać «dwóch stron»? O edukacji, ewolucji i teorii inteligentnego projektu. Rozmowa z o. Michałem Chaberkiem, dominikaninem, doktorem teologii fundamentalnej, autorem książki Stworzenie czy ewolucja? Dylemat katolika", Christianitas 2014, nr 58, s. 72 [70-82], https://tiny.p1/g2szj (27.12.
} 2018). 
ności. Bóg pozwala światu być takim, jakim się staje w swojej ciągłej ewolucji. On nie interweniuje bez przerwy, ale raczej pozwala, uczestniczy, kocha. ${ }^{171}$

Druga ze wspomnianych wypowiedzi to oficjalne stanowisko Rady Naukowej Konferencji Episkopatu Polski:

W rozumieniu chrześcijańskim Bóg nie tylko uczynił swoje stworzenie, lecz jest Tym, który wciąż podtrzymuje je w istnieniu, pozwala mu rozwijać się i prowadzi ku właściwemu celowi. [...] W tym ujęciu — ujęciu chrześcijańskiej nauki wiary — nasz świat nie znajduje się w szponach ślepych sił, nie jest chaosem ani ofiarą brutalnych determinizmów. Ewolucja wiedzie ku pojawieniu się człowieka jako istoty wolnej, odpowiedzialnej i świadomej. Ale sama z siebie tego progu nie pokonuje. W celu powołania do życia człowieka Bóg mógł posłużyć się jakąś istotą przygotowaną na planie cielesnym przez miliony lat ewolucji i tchnąć w nią duszę - na swój obraz i podobieństwo. Oznacza to, że dla chrześcijan ewolucja pozostaje w harmonii z wielkim planem Boga, którego cel stanowi powołanie człowieka do najwyższej godności obrazu Jego Syna jednorodzonego, umarłego i zmartwychwstałego. ${ }^{172}$

Obydwie wypowiedzi miejscami brzmią tak, że trudno je zrozumieć (na przykład „On nie interweniuje bez przerwy, ale raczej pozwala, uczestniczy, kocha”, czy „świat nie [...] jest [...] ofiarą brutalnych determinizmów”). Druga z przytoczonych wypowiedzi w niezauważalny prawie sposób łączy też dwa podejścia: teizmu naturalistycznego („,w rozumieniu chrześcijańskim Bóg nie tylko uczynił swoje stworzenie, lecz jest Tym, który wciąż podtrzymuje je w istnieniu”) i teizmu tradycyjnego (,w celu powołania do życia człowieka Bóg mógł posłużyć się jaką́ istotą przygotowaną na planie cielesnym przez miliony lat ewolucji i tchnąc w nią duszę — na swój obraz i podobieństwo"). W ramach tego ostatniego Bóg poprzez interwencje stwarza duszę, gdyż ewolucja sama tego progu nie pokonuje. Zaś w ramach nowego teizmu odrzuca się koncepcję powstania człowieka jako specjalnego aktu Boga, ${ }^{173} \mathrm{~W}$ miejsce tego przyjmując,

${ }^{171}$ George V. Coyne SJ, „Przypadek jako metoda Boskiego stwarzania”, przeł. Dariusz Sagan, Filozoficzne Aspekty Genezy 2005/2006, t. 2/3, s. 42, 44 [39-44], https://tiny.pl/xhkgd (27. 12.2018).

${ }^{172}$ Stanisław W. Wielgus (w imieniu Rady Naukowej Konferencji Episkopatu Polski), „Kościół wobec ewolucji. Stanowisko Rady Naukowej Konferencji Episkopatu Polski. 27.11.2006”, Opoka.org.pl, https://tiny.pl/tqfk8 (27.12.2018).

${ }^{173}$ Por. Bylica, „Główne założenia...”, s. 56; Plantinga, „Naturalizm metodologiczny...”, s. 70-74; William A. DembsкI, „Śmierć i Upadek: dlaczego teistyczny ewolucjonizm nie łagodzi 
że „Boska kreatywność ujawnia się w procesie ewolucyjnych przemian”. ${ }^{174} \mathrm{Ta}$ ostatnia teza, o czym warto pamiętać, pozostaje w rażącej niezgodzie $\mathrm{z}$ ewolucjonistycznym przekonaniem o nieukierunkowanym charakterze procesów przyrodniczych:

nie więcej jest, zdaje się, celowości w zmienności istot żywych i w działaniu doboru naturalnego niż w kierunku, w którym wieje wiatr. ${ }^{175}$

Dlatego trudno znaleźć jakiegokolwiek biologa, który by utrzymywał tezę o kreatywności Boga w procesach ewolucyjnych. ${ }^{176}$ Wyjątkiem wydaje się biolog ewolucyjny Jan Kozłowski, który twierdzi, że

jeśli uznamy Boga za Pana Zjawisk Losowych, co wydaje się przecież rozsądne, to miał On wiele możliwości działania w takim kierunku, by świat był taki, jaki jest, by powstał człowiek, zdolny do refleksji i uznania istnienia Boga. ${ }^{177}$

Powyższą tezę opatrzył on jednak zastrzeżeniem, sugerującym, że nie wypowiada się tu jako biolog:

Musimy jednak pamiętać, że rozważania takie są bezsensowne z przyrodniczego, ale tylko przyrodniczego, punktu widzenia, gdzie zjawiska losowe musimy traktować jako losowe i nie ma potrzeby dopatrywać się w ludzkiej egzystencji głębszego przyrodniczego sensu. Jeśli będziemy przestrzegać zasady, że zawsze trzeba pamiętać, czy wy-

problemu zła", przeł. Dariusz Sagan, Filozoficzne Aspekty Genezy 2013, t. 10, s. 162-163 [159176], https://tiny.pl/xh2nj (27.12.2018).

${ }^{174}$ Por. Życiński, „Ewolucyjna wizja...”, s. 88. Por. też Jitse M. van der MeER, „Pojęcie natury ludzkiej w nauce i teologii”, przeł. Radosław Plato, Filozoficzne Aspekty Genezy 2013, t. 10, s. 246 [243-250], https://tiny.pl/tqf8h (27.12.2018); Jitse M. van Der MeER, „Przekonania towarzyszące, ideologia i nauka”, przeł. Dariusz Sagan, Filozoficzne Aspekty Genezy 2016, t. 13, s. 168 [153-194], https://tiny.pl/gzjrs (27.12.2018).

${ }^{175}$ Karol DARwIN, Dziela wybrane. Autobiografia i wybór listów, t. 8, przeł. A. Iwanowska, A. Krasicka, J. Połtowicz i S. Skowron, Państwowe Wydawnictwo Rolnicze i Leśne, Warszawa 1960, s. 44. Por. też MaLec, „Teologiczne dylematy...”, s. 70-78; BYlica, „Darwin o celowości...”, s. 265; JodKowsKI, „Kreacjonizm a naturalizm...”, s. 12-14.

${ }^{176}$ Por. JoDKowsKI, „Dlaczego ewolucjonizm...”, s. 66; JoDKowsKI, „Kreacjonizm a naturalizm...", s. 14-19; JoDKOWSKI, Metodologiczne aspekty..., s. 301-302.

${ }^{177}$ Jan KozŁowski, „Teoria ewolucji: czy konflikt między nauką i wiarą jest nieunikniony?”, Nauka 2005, nr 3, s. 61 [49-62], https://tiny.pl/tqfs5 (22.12.2018). 
powiadamy się, stojąc po przyrodniczej czy po metafizycznej stronie linii demarkacyjnej, nie będzie konfliktu [między nauką i wiarą]. ${ }^{178}$

Nawiasem mówiąc, warto zauważyć, że również część uczonych z amerykańskiej National Academy of Sciences zdaje się nie dostrzegać faktu wykluczania się podejść ewolucjonistycznego i teistycznego:

Wiele religijnych osób, włączając w to wielu uczonych, utrzymuje, że Bóg stworzył Wszechświat oraz różne procesy kierujące fizyczną i biologiczną ewolucją, oraz to, że następstwem tych procesów było powstanie galaktyk, naszego systemu słonecznego i życia na Ziemi. Przekonanie to, niekiedy nazywane „teistycznym ewolucjonizmem”, nie pozostaje w konflikcie z naukowymi wyjaśnieniami procesów ewolucji. W rzeczy samej, odzwierciedla ono niezwykły i inspirujący charakter fizycznego wszechświata, który odsłania kosmologia, paleontologia, biologia molekularna i wiele innych nauk. ${ }^{179}$

Istnieją jednak biologowie, na przykład James Lovelock czy Rupert Sheldrake, którzy łączą swoje ewolucyjne przekonania z panteizmem. ${ }^{180}$ Tego typu fuzję wyjaśnia się w sposób następujący:

jeżeli badacz przyrody ma jednak wewnętrzne, subiektywne przekonanie o tym, że istnieje absolut, rzeczywistość nadprzyrodzona, niefizyczna — tradycja empiryczna nauki będzie go skłaniała do poglądów panteistycznych, utożsamiających Boga z naturą, czy deistycznych. W ramach takich poglądów jeżeli Bóg jest, to nie ingeruje w prawa natury. ${ }^{181}$

\footnotetext{
${ }^{178}$ KozŁowski, „Teoria ewolucji...”, s. 61. Por. też LemańsKa, „Ewolucja jako...”, s. 355.

${ }^{179}$ Ayala, Cicerone, Clegg, Dalrymple, Dickerson, Gould, Herschbach, Kennedy, McInerney, Moore, Ostriker, Rupp, Scott, Schulz, and Stanley, Science and Creationism..., s. 7 [wyróżnienia dodane]. Por. też Michael J. BeHE, „Filozoficzne zarzuty stawiane hipotezie inteligentnego projektu: odpowiedź na krytykę”, przeł. Dariusz Sagan, Filozoficzne Aspekty Genezy 2004, t. 1, s. 116 [115-139], https://tiny.pl/gt9nw (27.12.2018); SAGAN, „Teoria inteligentnego projektu a ewolucjonizm...", s. 87.

Nienaukowy charakter, gdyż nie są testowalne metodami naukowymi, mają jedynie „kreacjonizm, teoria inteligentnego projektu i inne ujęcia, dopuszczające nadnaturalną interwencję" (Ayala, Cicerone, Clegg, Dalrymple, Dickerson, Gould, Herschbach, Kennedy, Mcinerney, Moore, Ostriker, Rupp, Scott, Schulz, and Stanley, Science and Creationism..., s. 25).

${ }^{180}$ Por. JodKowsKi, Metodologiczne aspekty..., s. 302.

${ }^{181}$ Jerzy LuKIERSKI, „Nauka i religia — czy można pogodzić?”, s. 3 [1-5], https://tiny.pl/gzpd2 (27.12.2018).
} 
W ramach teizmu naturalistycznego odrzuca się także doktrynę o dualizmie duszy i ciała, zamiast tego proponując psychofizyczne ujęcie jedności człowieka oraz ciągłość przejścia między typowo ludzkim a zwierzęcym psychizmem. ${ }^{182}$ Doktrynę o stworzeniu świata przez Boga i nieustannym nim kierowaniem zastępuje się doktryną o Boskim podtrzymywaniu świata $\mathrm{w}$ istnieniu (immanentnej obecności Boga w prawach przyrody). ${ }^{183}$

Krytykowana jest też koncepcja „Boga zapchajdziury” (God of the gaps), ${ }^{184}$ w której Bóg „wprowadzony był do wypełniania aktualnych luk w przyrodniczym obrazie świata". ${ }^{185}$ Zakłada się, że w naturalistycznym opisie zdarzeń zachodzących w świecie przyrody nie istnieją żadne luki ${ }^{186}$ (założenie to, jak zauważono, ma jednak charakter aprioryczny ${ }^{187}$ ). W miejsce koncepcji Boga w lukach wiedzy przyjmuje się nieinterwencjonistyczne, naukowo niewykrywalne

\footnotetext{
${ }^{182}$ Por. BylicA, „Główne założenia...”, s. 59-60.

${ }^{183}$ Por. Bylica, „Główne założenia...”, s. 56; Mieczysław PAJewski, „Papież Benedykt XVI potwierdza kapitulancką postawę kościoła katolickiego wobec ateistycznie zorientowanych uczonych", Idź Pod Prąd 2008, nr 11 (52), s. 10, https://tiny.pl/tqmb7 (15.12.2018).

${ }^{184}$ „«Bóg zapchajdziura» umarł” (John C. Polkinghorne, Nauka i stworzenie. Poszukiwanie zrozumienia, przeł. Marek Chojnacki, Wydawnictwo Apostolstwa Modlitwy, Kraków 2008, s. 41). Dzieje tego argumentu omawia Stanisław WszołeK w tekście „W obronie argumentu «God of the gaps»", Zagadnienia Filozoficzne w Nauce 1999, t. 23, s. 103-118, https://tiny.pl/tqfsz (27. 12.2018). Por. też Erkki V.R. KoJonen, „The God of the Gaps, Natural Theology and Intelligent Design", Journal of Analytic Theology 2016, vol. 4, s. 296-305 [291-316], https:/tiny.pl/tqf6r (27.12.2018); Andrzej ZавоєотNY, „Naturalizm metodologiczny w nauce - dylemat teisty”, Filozoficzne Aspekty Genezy 2016, t. 13, s. 38 [25-48], https://tiny.pl/gzplf (27.12.2018).

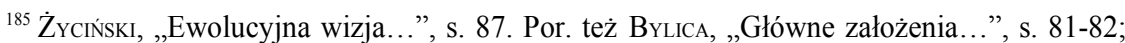
BYLICA, „Zarys modelu...” s. 231-232; Piotr BylicA, „Wpływ teizmu chrześcijańskiego na rozumienie nauki oraz relacji między sferą przyrodniczą i nadprzyrodzoną w okresie rewolucji naukowej XVI-XVII w. a teza o wrodzonym konflikcie między nauka a religia”, Kwartalnik Historii Nauki i Techniki 2013, nr 1, s. 83-84 [73-90], https://tiny.pl/xhnln (27.12.2018); Paul DAVIES, „Fizyka i umysł...”, s. 20-21; Plantinga, „Naturalizm metodologiczny...”, s. 74-76.

Plantinga w przywoływanym wyżej tekście (s. 74) utrzymuje, że to „strach przed teologią Boga w lukach wiedzy oraz odraza do niej” skłania niektórych teistów do akceptacji naturalizmu metodologicznego. Por. też Martin HiLberT, „Darwinowskie podziały. Papież, kardynał, jezuita i ewoluująca debata nad pochodzeniem”, przeł. Dariusz Sagan, Filozoficzne Aspekty Genezy 2005/2006, t. 2/3, s. 59 [45-63], https://tiny.pl/gzj8m (27.12.2018).

${ }^{186}$ Por. BylicA, „Zarys modelu...”, s. 252.

${ }^{187}$ Por. Steven Lloyd, „«God of the Gaps»: A Valid Objection?”, Origins 2005, vol. 42, s. 9 [7-10], https://tiny.pl/gzlgr (27.12.2018).
} 
działanie Boga w przyrodzie. ${ }^{188}$ (Jedynym wyjątkiem, na jaki przystają tu zwolennicy tego podejścia, jest uznanie Chrystusa za wcielenie Boga na ziemi. ${ }^{189}$ ) Przyjmuje się też tezy o spójności Boga z Jego naturą oraz o Jego racjonalności, co ma świadczyć przeciwko interwencjonistycznym tezom mówiącym o łamaniu przez Boga ustalonego przez Niego porządku przyrody oraz o czynionych przez Niego cudach.

Warto w tym miejscu nadmienić, że to ostatnie pozostaje w jawnej niezgodzie z nauczaniem apostolskim kościoła rzymskokatolickiego:

Jeśli ktoś twierdzi, że cuda są w ogóle niemożliwe i stąd wszystkie o nich opowiadania, nawet zawarte w Piśmie Swiętym, trzeba uznać za baśnie i mity; albo że cudów nigdy nie można poznać w sposób pewny, ani że na ich podstawie nie da się należycie uzasadnić Bożego pochodzenia chrześcijańskiej religii — niech będzie wyklęty. ${ }^{190}$

Nakreślone wyżej uwagi dotyczące teizmu naturalistycznego pozwalają na zdefiniowanie tej odmiany EUO i sformułowanie jej twardego jądra.

Twarde jądro naturalistycznego teizmu może brzmieć tak: Bóg istnieje i jest immanentnie obecny w prawach przyrody ${ }^{191}$ (nie działa w przyrodzie w empirycznie wykrywalny sposób).

Jak pokazano wyżej, teizm naturalistyczny zabrania odwoływania się zarówno do wyjaśnień powołujących się na przyczyny nadnaturalne i inteligentne. Dlatego EUO teistycznej odmiany naturalizmu jest nakazem przyjmowania jedynie naturalistycznych wyjaśnień dla faktów i procesów, wraz z jednoczesnym zakazem przyjmowania wyjaśnień antynaturalistycznych, czyli wyjaśnień powo-

\footnotetext{
${ }^{188}$ Por. BylicA, „Zarys modelu...”, s. 234-235.

Istnieje też pogląd, w myśl którego mówienie o subtelnym zestrojeniu człowieka i wszechświata jest koncepcją Boga-zapchajdziury (por. LARSON, „O argumencie...”, s. 203).

${ }^{189}$ Por. Bylica, „Główne założenia...”, s. 56.

${ }^{190}$ Sobór Watykański I, Konstytucja dogmatyczna o wierze katolickiej, kanon 4 (cyt. za: Andrzej Siemieniewski, „Między cudownością a cudem”, Teologia Duchowości 22 grudnia 2018, https://tiny.pl/tqfvm [27.12.2018]). Por. też ByLıcA, „Główne założenia...”, s. 59-60; BYLıCA, „Kazimierza Jodkowskiego...", s. 192.

${ }^{191}$ Por. Brad S. Gregory, „No Room for God?: History, Science, Metaphysics, and the Study of Religion", History and Theory 2008, vol. 47, no. 4, s. 503-504 [495-519], https://tiny.pl/tqfv7 (27.12.2018).
} 
łujących się na przyczyny nadnaturalne (antynaturalizm ${ }_{1}$ ) i inteligentne (antynaturalizm 2 ). ${ }^{192}$

„Umiejętne czytanie” ksiąg Pisma Świętego, do jakiego zachęcają zwolennicy teistyczno-naturalistycznego EUO, prowadzi do szeregu problemów, z którymi zmierzyć się musi to podejście. Czytanie takie ma bowiem poważne koszty światopoglądowe i epistemiczne:

W wykonaniu niektórych autorytetów teologicznych często przyjmuje [...] [też] postać karykaturalną, gdyż z góry przyjmowana jest konieczność takiej reinterpretacji treści teizmu chrześcijańskiego, by uzgodnić go ze sprzeczną z nim filozofią naturalistyczną. ${ }^{193}$

Dla współczesnego człowieka światopogląd teizmu ewolucjonistycznego, sytuujący „działania Boga w sferach uznanych za niedostępne poznaniu naukowemu", jest bardzo trudny do zaakceptowania, gdyż: ${ }^{194}$

nie przekonują go wysiłki teologów, „dolepiających” do ewolucjonizmu jakiś metafizyczny drugi świat ${ }^{195}$

i

pogłębiających empiryczny poziom przyrody poprzez analizy teologiczne, ${ }^{196}$

które próbują pogodzić naukę i religię przez podkreślanie niezupełności naukowego opisu świata. Z drugiej jednak strony wyznawany światopogląd nie musi charakteryzować się logiczną spójnością. ${ }^{197}$ Dlatego też, jak zauważono, ogół chrześcijan, za wyjątkiem orientacji fundamentalistycznych, które stanowią margines współczesnego chrześcijaństwa, akceptuje przekonanie, w myśl które-

\footnotetext{
${ }^{192}$ Por. Kilian, „Geneza epistemicznych...”, s. 150.

${ }^{193}$ ByLıCA, „Nauka światopoglądowo...”, s. 80.

${ }^{194}$ Por. Bylica, „Główne założenia...”, s. 80.

${ }^{195}$ Jodkowski, „Dlaczego ewolucjonizm...”, s. 67. Por. też BYLIcA, „Zarys modelu...”, s. 249250.

${ }^{196}$ Por. Koтошісz, „Józefa Życińskiego...”, s. 250.

${ }^{197}$ Por. np. Zachariasz, Poznanie teoretyczne..., s. 37-38; Zachariasz, Filozofia..., s. 184185.
} 
go „Bóg stwarza przy pomocy przypadkowych mutacji, selekcjonowanych walką o przetrwanie". ${ }^{198}$

W ramach teistycznego ewolucjonizmu mówi się, że dla religii zarezerwowany jest obszar zagadnień, które nie poddają się empirycznemu badaniu. Obszar taki ex definitione wykracza poza kompetencje nauki i tu właśnie jest miejsce dla refleksji religijnej: ${ }^{199}$

Świat zamieszkuje sześć miliardów ludzi. [...] Potrzebują oni celu i sensu życia. [...] Jeśli wydaje nam się, że uda mam się ich przekonać, by wiedli racjonalne życie oparte [wyłącznie] na wiedzy naukowej, to nie tylko śnimy, lecz wierzymy też w dobrą wróżkę. ${ }^{200}$

Wiedza naukowa może wzbogacić estetyczne i moralne postrzeganie świata i rzucić światło na sens życia i świata, ale te kwestie pozostają poza jej kompetencjami. ${ }^{201}$

\footnotetext{
${ }^{198}$ JoDKOwSKI, „Ruch kreacjonistyczny...”, s. 241-242. nej:

Spostrzeżenie to na polskim gruncie potwierdziły badania Ośrodka Badania Opinii Publicz-

63\% wszystkich badanych uważa, że naukę o biologicznym stworzeniu człowieka można pogodzić z wiarą, że człowieka stworzył Bóg, zaś $23 \%$ sądzi, że tego pogodzić nie można.

Ośrodek Badania Opinii Publicznej, „Ewolucja po polsku”, TNS OBOP sondaż z 3-6.11. 2006, s. 1 [1-16], https://tiny.p1/tqfvj (22.12.2018).

Zaś w USA 38\% respondentów jest przekonanych, że ewolucja biologiczna da się pogodzić z przekonaniem, że proces ten był kierowany przez Boga (por. Jerry A. CoYne, „Science, Religion, and Society: The Problem of Evolution in America", Evolution. International Journal of Organic Evolution 2012, vol. 66, no. 8, s. 2654 [2654-2663], https://tiny.pl/thtdt [26.12.2018]).

${ }^{199}$ Zagadnienia te dotyczą pojawiania się w naukowym obrazie świata tak zwanych „luk metafizycznych, epistemologicznych i aksjologicznych". Luki te wyrażane są odpowiednio pytania mi: „,dlaczego istnieje raczej coś niż nic?”; „dlaczego świat jest zrozumiały?”; ,jaki sens i wartość ma wszystko, co istnieje?” Luka metafizyczna zawiera zespół problemów dotyczących metafizycznej podstawy świata. Luka epistemologiczna obejmuje problemy istnienia ogólnego inteligibilnego porządku świata przyrodniczego i naszych zdolności do jego racjonalnej pojmowalności. Luka aksjologiczna to obszar sądów wartościujących, które dotyczą faktów (por. Michael HeLLer, „Chaos, Probability, and the Comprehensibility of the World”, w: Michael Heller, Creative Tension: Essays on Science and Religion, Templeton Foundation Press, West Conshohocken, Pennsylvania 2003, s. 142-143 [127-143], https://tiny.pl/tq2rp [26.12.2018]; BYLICA, „NDE a empiryczność...”, s. 91-95; WszoŁeK, „W obronie argumentu...”, s. 114-115).

${ }^{200}$ Wypowiedź Francisco J. Ayali przytaczana za: Johnson, „A Free-for-All...”.

${ }^{201}$ Ayala, Dar Karola..., s. 166.
} 
Jeśli współczesny człowiek wierzy w Boga, to nie jest przekonany, że Jego działania odbywają się w jakiejś pozaempirycznej sferze. Oczekuje raczej, że działania te mają empirycznie dostrzegalne skutki, co przybliża go do poglądów kreacjonistycznych czy teorii inteligentnego projektu. Obydwa poszukują śladów Boga w sferze empirii. ${ }^{202}$ Dla takiego człowieka

pogląd stwierdzający, że Bóg stworzył świat, podtrzymuje go i działa za pomocą praw przyrody w bardzo subtelny sposób, tak subtelny, że jego działanie jest niewykrywalne [...] nie różni się od ateizmu, ${ }^{203}$

gdyż

Bóg jest tylko teologicznym dodatkiem, niesprawiającym żadnej, rozpoznawalnej metodami naukowymi różnicy w świecie przyrody. ${ }^{204}$

Z podobnych powodów pogląd ten jest nieodróżnialny od deizmu:

Teistyczny ewolucjonizm w [tym] wydaniu [...] jest deizmem wszędzie tam, gdzie możemy coś zaobserwować, zmierzyć czy zbadać. Różni się zaś od niego tylko stwierdzeniem, że Bóg jest zawsze i wszędzie aktywnie obecny, mimo iż tej obecności w żaden sposób nigdy i nigdzie wykryć nie jesteśmy i nie będziemy w stanie. ${ }^{205}$

Wysiłki uwolnienia wiary chrześcijańskiej z jej istotnych treści również

zupełnie nie wpływają na większość uczonych. W świetle postępu naukowego tego stulecia taka teologiczna akrobatyka jest osobliwym anachronizmem ${ }^{206}$

${ }^{202}$ Por. JodKowsKi, „Dlaczego ewolucjonizm...”, s. 69-70.

${ }^{203}$ William B. Provine, „Progress in Evolution and Meaning of Life”, w: Matthew H. NitecK (ed.), Evolutionary Progress, University of Chicago Press, Chicago 1988, s. 70 [49-74] (cyt. za: Piotr ByLıcA, „Konflikt między teizmem i nauką bazującą na naturalizmie - w ujęciu Phillipa E. Johnsona", Zagadnienia Naukoznawstwa 2003, nr 3-4 (157-158), s. 234 [227-238], https://tiny. pl/xh894 [27.12.2018]). Por. też Michał Warzyc, „Dar, który wciąż jest wyzwaniem”, Semina Scientiarum 2009, nr 8, s. 132-133 [129-133], https://tiny.pl/tq591 (27.12.2018).

${ }^{204}$ SAGAN, „Teoria inteligentnego projektu a ewolucjonizm...”, s. 91.

${ }^{205}$ Jodkowski, Spór ewolucjonizmu..., s. 77. Por. też SAGAN, „Teoria inteligentnego projektu a ewolucjonizm...", s. 93.

${ }^{206}$ Colin A. RusselL, Cross-Currents: Interactions Between Science and Faith, InterVarsity Press 1985, s. 252. Fragmenty w przekładzie Jodkowskiego, „Dlaczego ewolucjonizm...”, s. 69. Por. też BylicA, „Główne założenia...”, s. 89; ByLicA, „Konflikt...”, s. 234. 
i de facto jest strategią ,"przemycania Boga [do nauki] tylnymi drzwiami”. ${ }^{207}$

Na koszty epistemiczne „umiejętnego czytania” ksiąg Pisma Świętego składają się:

często wypowiadane twierdzenie, że współczesna biologia [ewolucyjna] i założenia judeochrześcijańskiej tradycji są w pełni zgodne, [które] jest fałszywe. ${ }^{208}$

Przede wszystkim dlatego, że ewolucja dokonująca się za pomocą jakichkolwiek Boskich interwencji nie jest ewolucją Darwinowską:

Funta kłaków nie dałbym za teorię doboru naturalnego, gdyby, w którymkolwiek stadium powstawania gatunków, wymagała ona cudownych interwencji. ${ }^{209}$

Albo Bóg rządzi stworzeniem, co oznacza, że tak kierował ewolucją, by wytworzyła ludzi; albo nie rządzi. To pierwsze przekonanie nie jest darwinizmem, zaś to drugie nie jest teizmem. ${ }^{210}$

Inne elementy tych kosztów ${ }^{211}$ to nieuwzględnianie osiągnięć filozofii nauki. $Z$ jednej strony teizm naturalistyczny postuluje rozdzielność płaszczyzn na-

\footnotetext{
${ }^{207}$ Por. John Farrell, „It’s Time to Retire «Theistic Evolution»”, Forbes 19 March 2016, https://tiny.pl/tq59l (27.12.2018).

${ }^{208}$ Provine, „Progress in Evolution...”, s. 65. Fragment w przekładzie JodKowsKiEgo, „Dlaczego ewolucjonizm...", s. 76.

${ }^{209}$ List Karola Darwina do Karola Lyella z 11 października 1859 roku, w: Charles DARwIN, The Life and Letters of Charles Darwin. Volume II Including an Autobiographical Chapter, Edited by his Son Francis Darwin, William Clowes and Sons, Limited, London 1887, https://ti ny.pl/tq59n (27.12.2018). Por. też np. JoDKowski, „Dlaczego ewolucjonizm...”, s. 68-69; Richard DAWKINS, Ślepy zegarmistrz, czyli jak ewolucja dowodzi, że świat nie zostal zaplanowany, przeł. Antoni Hoffman, Biblioteka Myśli Wspótczesnej, Państwowy Instytut Wydawniczy, Warszawa 1994, s. 390; Coyne, Ewolucja jest faktem..., s. 31.

${ }^{210}$ Phillip E. Johnson, „Creator or Blind Watchmaker”, First Things January 1993, https://ti ny.pl/tq59k (27.12.2018).

${ }^{211}$ Zauważono też, że:
}

[a] Jeżeli ktoś twierdzi, że „Bóg mógł posłużyć się ewolucją”, to najpierw musi pożegnać klasyczną metafizykę wraz z wszystkimi jej zasadami.

Michał Chaberek OP, „Czy Bóg mógł się posłużyć ewolucją?”, Fronda 2012, nr 63, s. 91 [83-103]. Por. też wypowiedź Michała Chaberka w: Rowiński, „Dlaczego warto nauczać...”, s. 72; DemBSKI, „Odmiany naturalizmu...”, s. 51-52. 
uki i religii, ${ }^{212}$ uznając, że

rozwarstwienie poziomów poznania (poznanie przez naukę, poznanie przez wiarę i inne) jest faktem dokonanym. ${ }^{213}$

Dzięki tej rozdzielności przyjmować można, że tam, gdzie poznanie naukowe nie sięga, rozpoczyna się sfera empirycznie niewykrywalnej działalności Boga (mówi się nawet o „subtelnym ukryciu się” Boga w Księdze Natury). ${ }^{214}$ Jednakże współczesna filozofia nauki w zadowalającym stopniu wykazała, że ostre podziały kultury na naukę, filozofię, teologię i inne dziedziny są anachronizmem. Nieustannie mamy do czynienia z permanentnym, wzajemnym oddziaływaniem owych dziedzin kultury, co prowadzi do tezy, w myśl której podziały takie są bardzo arbitralne. ${ }^{215}$ Dlatego też zauważono, że

przy bliższym przyjrzeniu się wspomniany fakt rozdzielności płaszczyzn okazuje się jednak tylko rezultatem podjętych decyzji. ${ }^{216}$

[b] Skoro Bóg kieruje ewolucją i odpowiada za każde wydarzenie, w takim razie odpowiada za każde zło.

Bylica, „Konflikt między...”, s. 234. Por. też DemBski, „Odmiany naturalizmu...”, s. 52-53.

${ }^{212}$ Por. np. ŻyciŃski, „Naturalizm ontologiczny...”, s. 8. Por. też JoDKowski, „Eskapizm teologii...”, s. 274-279; JoDKowski, „Dlaczego ewolucjonizm...”, s. 70-71.

${ }^{213}$ Michał Heller, Wszechświat i Słowo, Społeczny Instytut Wydawniczy Znak, Kraków 1981, s. 173. Por. też MACEK, Teologia nauki..., s. 59-61.

${ }^{214}$ Por. Jacek MARCinIEC, „Piękno Wszechświata. Harmonia nauki i wiary w twórczości arcybiskupa Józefa Życińskiego", w: Bogdan WszoŁek (red.), Astronomia — nauka i wiara. Tom II. Pamięci księdza Bonawentury Metlera, Stowarzyszenie Astronomia Nova oraz Instytut Fizyki Akademii im. Jana Długosza w Częstochowie, Częstochowa 2015, s. 140-141 [133-144].

${ }^{215}$ Por. JoDKowski, „Eskapizm teologii...”, s. 274-275; JoDKowski, „Dlaczego ewolucjonizm...”, s. 70; A. Rupert HALL, Rewolucja naukowa 1500-1800. Ksztaltowanie się nowożytnej postawy naukowej, przeł. Tadeusz Zembrzuski, Instytut Wydawniczy PAX, Warszawa 1966, s. 154-155; Jan WASzKIEWICZ, „O świętości, harmonii Wszechświata i rewolucji naukowej, czyli o miejscu matematyki w kulturze", Matematyka - Społeczeństwo - Nauczanie 1993, nr 11, s. 4 [2-10], https://tiny.pl/tq59b (27.12.2018); Thomas S. KuHn, Przewrót kopernikański. Astronomia planetarna w dziejach myśli, przeł. Stefan Amsterdamski, PWN, Warszawa 1966, s. 370371; KUHN, Struktura rewolucji..., s. 83-84; Frederick SuPPE, „,The Search for Philosophic Understanding of Scientific Theories", w: Frederick SupPE (ed.), The Structure of Scientific Theories, University of Illinois Press, Urbana - Chicago — London 1977, s. 126-127 [1-241].

${ }^{216}$ JoDKowski, „Eskapizm teologii...”, s. 262. 
Z drugiej zaś strony teiści ci odrzucają, bardzo niewygodną dla tego ujęcia, tezę o niewspółmierności teorii naukowych, opowiadając się za kumulatywnym obrazem nauki. ${ }^{217}$ Akceptacja kumulatywizmu ułatwia utrzymywanie tezy o dostosowywaniu Pisma Świętego do naukowego obrazu świata:

Ilekroć zaistnieje konflikt pomiędzy dosłowną interpretacją jakiegoś tekstu biblijnego a prawdą dotyczącą przyrody, udowodnioną przy pomocy wiarygodnych argumentów, chrześcijanin powinien poddać tekst biblijny reinterpretacji metaforycznej. ${ }^{218}$

Gdyby naukowy obraz świata ulegał radykalnym przeobrażeniom w następstwie pojawiających się niewspółmiernych teorii naukowych, to dostosowywanie takie byłoby bardzo skomplikowane, a może nawet wręcz niewykonalne. Reinterpretacje metaforyczne nieustannie byłyby uzgadniane ze zmiennymi prawdami przyrodniczymi. ${ }^{219}$

Jeszcze innym epistemicznym kosztem akceptacji tego EUO jest to, że układ ten de facto ma dwie „święte księgi”, z których jedna jest „bardziej święta" niż druga. Księga natury stanowi punkt odniesienia dla umiejętnego czytania drugiej, Pisma Świętego. Biblia staje się w takim ujęciu zredukowaną do postulatów etycznych księgą, która mówi wyłącznie o sferach wartości moralnych i sensu życia, pozostawiając księdze natury zagadnienie adekwatnego opisu świata:

zasada ogólna jest taka, że w Piśmie Świętym jest objawione to, co dotyczy naszej relacji wobec Boga, naszego zaangażowania $\mathrm{w}$ dążenie do zbawienia, natomiast biologia, zoologia czy inne dyscypliny przyrodnicze nie są w sposób autorytatywny przekazywane w Piśmie Świętym. ${ }^{220}$

\footnotetext{
${ }^{217}$ Por. BylicA, „Główne założenia...”, s. 58-59.

${ }^{218}$ Ernan McMuldin, Ewolucja i stworzenie, przeł. Jacek Rodzeń, Ośrodek Badań Interdyscyplinarnych przy Wydziale Filozofii Papieskiej Akademii Teologicznej, Kraków 1990, s. 2. Por. też komentarz do tej tezy: JodKоwski, „Eskapizm teologii...”, s. 262-264, 279-282.

${ }^{219}$ Por. Kazimierz JoDKowski, „NOMA, cudy i filtr eksplanacyjny”, Roczniki Filozoficzne 2005, t. 53, nr 2, s. 97-98 [83-103], https://tiny.pl/tq5cj (28.12.2018); Kazimierz JodкowsкI, „Konflikt nauka-religia a teoria inteligentnego projektu", w: JoDKоwsкi (red.), Teoria inteligentnego projektu..., s. 151 [145-180], https://tiny.pl/qzq8f (28.12.2018); vAN DER MEER, „Pojęcie natury...”, s. 243; BylicA, „Kazimierza Jodkowskiego...”, s. 197.

${ }^{220}$ Wypowiedź Józefa Życińskiego w: Życiński i HeTMański, „Religijny a naukowy obraz świata...", s. 70
} 
$\mathrm{W}$ tej ostatniej sprawie, jak zauważono, teizm naturalistyczny podąża za ewolucjonistami, którzy „religię w światłej postaci” ${ }^{221}$ uznają wyłącznie za fenomen moralny. ${ }^{222}$ Jednakże, co warto $\mathrm{w}$ tym miejscu podkreślić, ów fenomen dla niektórych ewolucjonistów stracił już swoją wyjątkowość:

Jeżeli religia $[\ldots]$ może być systematycznie analizowana i wyjaśniana jako produkt ewolucji mózgu, [to] jej moc jako zewnętrznego źródła moralności zostaje raz na zawsze zniweczona. ${ }^{22}$

„Religii w światłej postaci” nie pozostaje zatem żadna znacząca funkcja. Religia ta staje się zbyteczna.

Dostrzeżono też, że w tym, co robią zwolennicy EUO teizmu naturalistycznego, widać pewną analogię do procedur opisywanych w Lakatosowskich zaszczepionych programach badawczych. Naturalizm został zaszczepiony na chrześcijańskim teizmie i „wywalczywszy sobie bezpieczną pozycję, przystąpił do ataku" ${ }^{224}$ na niezmienność twierdzeń religii. ${ }^{225}$ Następstwem tego ataku jest metaforyzacja niezgodnych $\mathrm{z}$ naturalizmem twierdzeń tekstu biblijnego oraz światła postać religii, co w sumie sprowadza się do rozsadzania starego systemu świata. 226

Zabiegi mające na celu połączenie naturalizmu z teizmem określone zostały jako „próba zwykłego ochrzczenia darwinizmu” 227 i „bezwartościowe badania”, ${ }^{228}$ które mają „niebiblijny charakter”. ${ }^{229}$ Dostrzeżono też, że jest to próba

\footnotetext{
${ }^{221}$ Por. Coyne, Ewolucja jest faktem..., s. 18.

${ }^{222}$ Por. BYLICA, „Główne założenia...”, s. 66; Stephen Jay Gould, „Nonoverlapping Magisteria”, Filozoficzne Aspekty Genezy 2014, t. 11, s. 8 [7-21], https://tiny.pl/tq5c4 (28.12.2018); HILBERT, „Darwinowskie podziały...”, s. 61-63.

${ }^{223} \mathrm{~W}_{\text {ILSON, }}$ O naturze..., s. 212.

${ }^{224}$ Imre LaKatos, „Falsyfikacja a metodologia naukowych programów badawczych”, w: Imre Lakatos, Pisma z filozofii nauk empirycznych, przeł. Wojciech Sady, Biblioteka Wspótczesnych Filozofów, Wydawnictwo Naukowe PWN, Warszawa 1995, s. 104 [3-169].

${ }^{225}$ Por. Bylica, „Kazimierza Jodkowskiego...”, s. 197.

${ }^{226}$ Por. LaKatos, „Falsyfikacja a metodologia...”, s. 104.

${ }^{227}$ Wypowiedź Jaya Richardsa w: Michał CHABEREK OP, „Neodarwinizm skończy jak marksizm. Rozmowa z Jay'em W. Richardsem”, Fronda 2012, nr 63, s. 90 [43-47].
} 
pogodzenia dwóch niewspółmiernych ujęć: dualizmu i interwencjonizmu teizmu z monizmem i naturalizmem przyrodoznawstwa, ${ }^{230}$ zaś

ich stanowisko staje się wewnętrznie sprzeczne — rozumne stwarzanie, jakim ma być ewolucja, nie może mieć charakteru przypadkowego, przypadek bowiem jest zaprzeczeniem rozumnego i skierowanego na cel świadomego działania Stwórcy. ${ }^{231}$

Zatem,

jeśli myśli się po darwinowsku, to nie myśli się po chrześcijańsku. Chyba że, z głupoty czy konformizmu, przystajemy na duchowe rozdwojenie: w pracy jesteśmy darwinistami, w czasie wolnym - chrześcijanami. ${ }^{232}$

Warto w tym miejscu odnotować, że 23 lipca 2004 roku pojawiła się teologiczna odpowiedź na tak sformułowany zarzut niespójności. Wypowiedziała się w tej sprawie Międzynarodowa Komisja Teologiczna. Stwierdziła ona, że

zgodnie z katolickim rozumieniem boskiej przyczynowości autentyczna przygodność w stworzonym porządku rzeczy nie jest niezgodna z celową boską opatrznością. Boska przyczynowość i stworzona przyczynowość różnią się radykalnie co do rodzaju, a nie tylko co do stopnia. Dlatego też nawet rezultat prawdziwie przypadkowego naturalnego procesu może podpadać pod opatrznościowy Boski plan stworzenia. [...] Boska przyczynowość może być aktywna w procesie, który jest zarówno przygodny, jak i kierowany. Każdy mechanizm ewolucyjny, który jest przygodny, jedynie dlatego może być przygodny, bo Bóg go takim uczynił. ${ }^{233}$

\footnotetext{
${ }^{228}$ Richard P. Sloan, profesor medycyny behawioralnej w Columbia University Medical Center, w ten sposób (garbage research) określił badania finansowane przez Fundację Templetona nakierowane na próby łączenia nauki i religii (por. Johnson, „A Free-for-All...”).

${ }^{229}$ Por. CSSHS Editorial Staff, „Lesson 3...”.

${ }^{230}$ Por. SADY, „Dlaczego kreacjonizm...”, s. 225-226; ByLICA, „Kazimierza Jodkowskiego...", s. 210.

${ }^{231}$ JodKowsKI, „Kreacjonizm a naturalizm...”, s. 24. Por. też SADY, „Dlaczego kreacjonizm...”, s. 214, 225-226; ChabereK, „Św. Tomasz z Akwinu...”, s. 37-38; Delfino, „Naturalizm metodologiczny...", s. 139.

${ }^{232}$ SADY, „Dlaczego kreacjonizm...”, s. 226.

${ }^{233}$ International Theological Commission, „Communion and Stewardship: Human Persons Created in the Image of God”, 69, https://tiny.pl/tq5dp (28.12.2018).
} 
Odpowiedź ta uznana została za kolejną próbę „złagodzenia podziałów między kościołem a nauką". ${ }^{234}$ Jednak nie wszyscy teologowie zgadzają się z takim ujęciem sprawy. Główny redaktor Katechizmu Kościoła Katolickiego, kardynał Christoph Schönborn, z aprobatą przytaczał później ustęp 295 Katechizmu Kościoła Katolickiego:

Bóg, jak wierzymy, stworzył świat w sposób rozumny. Nie jest on produktem żadnej konieczności ani ślepego losu lub przypadku. ${ }^{235}$

Dał tym samym wyraz przekonaniu, w myśl którego „ewolucjonizm neodarwinowski w istocie nie jest zgodny z wiarą Kościoła w Boski cel i projekt stworzenia". ${ }^{236}$ Zauważono też, że

nie ma sensu twierdzenie, że Bóg celowo kierował bezcelowym procesem. To jest po prostu logicznie niespójne. ${ }^{237}$

Jeśli termin „ewolucja” rozumieć się będzie zgodnie z jego biologicznym sensem, to

jest to proces naturalny, to znaczy zachodzący na mocy praw przyrody, czyli niewymagający żadnego nadprzyrodzonego działania jakiegokolwiek bóstwa. [...] dla teologów było jasne, że stworzenie i ewolucja się wykluczają. Takie przekonanie dominowało w Kościele przynajmniej do pierwszej połowy XX wieku. ${ }^{238}$

A zatem „teistyczna ewolucja”

nie jest [...] tak[ą] ewolucj[ą], o której mówią dzisiejsi uczeni. ${ }^{239}$

\footnotetext{
${ }^{234}$ Por. Coyne SJ, „Przypadek jako...”, s. 40.

${ }^{235}$ SchönBorn, „Odnajdywanie zamysłu...”, s. 21.

${ }^{236}$ Coyne SJ, „Przypadek jako...”, s. 40. Por. też Hilbert, „Darwinowskie podziały...”, s. 4850; SADY, „Dlaczego kreacjonizm...”, s. 225-226.

${ }^{237}$ Wypowiedź Jaya Richardsa w: CHАвеRек, „Neodarwinizm...”, s. 44.

${ }^{238}$ Chaberek, „Czy Bóg mógł...”, s. 84-85.

${ }^{239}$ Wypowiedź Kazimierza Jodkowskiego w: Radosław Kopeć i Paweł ChoJecki, „Wywiad z prof. Jodkowskim”, Idź Pod Prad 2007, nr 11 (40), s. 8 [8, 11], https://tiny.pl/tq5ds (28.12. 2018). Por. też Dariusz Sagan, „Kościół a ewolucyjny materializm. George Sim Johnston: Czy Darwin miał rację? Katolicka teoria ewolucji, przeł. Joanna Kaliszczyk, Kraków, Wydawnictwo
} 
Mówi się także, że jest to stanowisko „albo logicznie sprzeczne, albo problematyczne z punktu widzenia teologii”, gdyż, w perspektywie teologicznej, przekonanie, że Bóg nie działa bezpośrednio w stworzeniu, „dla większości żydów i chrześcijan to zasadniczo problem pozabiblijny". ${ }^{240}$ Dlatego właśnie naturalistyczny teizm „to próba oszukania ludzi wierzących”. ${ }^{241}$

\section{Zauważono też, iż}

uznanie, że mechanizmy ewolucji są sposobem aktywności stwórczej Boga, wydaje się trudne do przyjęcia z kilku powodów. Po pierwsze, Bóg w tym ujęciu jawi się jako gigantyczny oszust, gdyż „dba o to, by Jego interwencje zawsze przypominały działania, jakich można by się spodziewać po ewolucji wskutek doboru naturalnego". Po drugie, dołączanie do naturalistycznych wyjaśnień hipotezy o „tkwiącym” za nimi Bogu jest zbędne, skoro wszystko daje się wyjaśnić naturalistycznie (zastosowanie brzytwy Ockhama: Bóg w schemacie naturalistycznego teistycznego ewolucjonizmu jest bytem ponad konieczność). A jeśli nawet machnie się ręką na te trudności, to i tak teizm, jaki otrzymujemy, nie jest teizmem chrześcijańskim. Pełna naturalistyczna akceptacja rzeczywistości wydaje się być nie do pogodzenia z istotą wierzeń chrześcijańskich. Można od biedy wierzyć w Boga i naturalistycznie wyjaśniać pochodzenie życia, poszczególnych gatunków i człowieka, ale czy pozostając chrześcijaninem można wyjaśniać takie wydarzenia jak dziewicze poczęcie, rozmnożenie chleba, zmartwychwstanie, wniebowstąpienie i wiele innych opisanych w Nowym Testamencie? Nie ma jakościowej różnicy między wykluczaniem wyjaśnień naturalistycznych w zastosowaniu do wydarzeń opisanych w Nowym Testamencie, a wykluczaniem ich także w zastosowaniu do niektórych wydarzeń ze Starego Testamentu, zwłaszcza z pierwszych rozdziałów Księgi Rodzaju. Jest to tylko różnica ilościowa. Jeśli za każde wydarzenie, jak chcą naturalistyczni teistyczni ewolucjoniści, odpowiada Bóg, to znika jakakolwiek autonomia świata, a pewne opisy w Nowym Testamencie świadczą o tej autonomii (np. Jezus uciszający morze). Nie ma też różnicy między zdarzeniami zwykłymi i cudami, bo wszystkie są cudami (po co więc Jezus czynił cuda, skoro każde wydarzenie jest cudem?). Bóg odpowiada też bezpośrednio za każde zło, za każdą tragedię, jakie

WAM, 2005”, Edukacja Filozoficzna 2005, vol. 40, s. 225 [223-228], https://tiny.pl/xhnmj (28. 12.2018).

${ }^{240}$ Por. wypowiedź Stephena C. Meyera w: Chaberek, „Wykrywanie informacji...”, s. 108.

Nawiasem mówiąc, dysjunkcja w tej wypowiedzi jest zbędna. Można bowiem uznać, że jest to stanowisko wewnętrznie sprzeczne i poważny problem teologiczny.

${ }^{241}$ Por. wypowiedź Kazimierza Jodkowskiego w: Kopeć i CHOJECKI, „Wywiad z prof. Jodkowskim...”, s. 8. Por. też Paweł Снолескі, „O co tyle szumu?”, Idź Pod Prąd 2007, nr 11 (40), s. 8, https://tiny.pl/tq5ds (28.12.2018). 
się przydarzają milionom ludzi. ${ }^{242}$

Dostrzeżono też więcej:

Żadna z wielkich monoteistycznych religii nie może wyrzec się realności cudów, żadna więc nie może pogodzić się z nauką. ${ }^{243}$

W następstwie tego „konflikt nauka-religia jest w swej najgłębszej istocie nieusuwalny". ${ }^{244}$

\section{Uwagi końcowe}

W niniejszym artykule wyjaśniłem, na czym polega światopoglądowe i ideologiczne zaangażowanie EUO, oraz wskazałem na światopoglądowe i ideologiczne składniki omawianych kategorii. W klasycznym, Diltheyowskim rozumieniu tego terminu, Weltanschauungen odpowiadać miały na dwie zagadki: życia i świata. Dotychczas przebadane EUO nie tylko udzielają odpowiedzi na te zagadki, ale i odpowiedzi te stanowią rdzeń funkcjonowania tych EUO.

Składnik światopoglądowy EUO nadnaturalistycznego interwencjonizmu jest dobrze widoczny w powszechnym odwoływaniu się w ramach tego EUO do Pisma Świętego (lub innych świętych ksiąg, na przykład Koranu czy Upaniszad). Cechą kreacjonizmu, uwypuklającą ów składnik, jest to, że wyniki badań naukowych są nieprzerwanie uzgadniane $\mathrm{z}$ odpowiednimi partiami świętych ksiąg.

Wzorcowym przykładem teorii opartej na naturalistycznym EUO jest gradualistyczny ewolucjonizm. Ten ostatni również odpowiada na wspomniane zagadki. Odpowiadając na te kwestie, nie odwołuje się do sił nadprzyrodzonych

\footnotetext{
${ }^{242}$ JodKowsKi, Metodologiczne aspekty..., s. 303-304. Przytaczany w drugim zdaniu fragment to wypowiedź Richarda Dawkinsa (por. DAwkins, Ślepy zegarmistrz..., s. 491).

${ }^{243}$ JodKowski, „NOMA, cudy...”, s. 91. Por. też SAGAN, „Kardynał Schönborn...”, s. 114-115; Piotr BylicA, „NOMA as the Cure for Conflict Between Science and Religion: Reply to Ludwik Kowalski's Commentary on the NOMA Principle", Filozoficzne Aspekty Genezy 2014, t. 11, s. 30-31 [29-34], https://tiny.pl/tq5v2 (28.12.2018); ByLICA, „Nauka światopoglądowo...”, s. 7678 .

${ }^{244}$ JodKоwsкi, „Konflikt nauka-religia...”, s. 157. Por. też JodKоwsкi, „Epistemiczne układy...”, s. 115; JoDKowsKI, Spór ewolucjonizmu..., s. 179-180.
} 
i uznawany jest za światopoglądową alternatywę dla chrześcijaństwa. Gradualizm ten ma również swoją „,świętą księgę”, której treść jest powszechnie akceptowana. „Księgą” tą jest metodologiczny naturalizm. Sama „księga” widoczna jest dopiero wtedy, gdy działania uczonych zestawi się z tym, co robią kreacjoniści, którzy dopasowują dane naukowe do swoich świętych ksiąg.

Artyficjalistyczny EUO ma swoją egzemplifikację w teorii inteligentnego projektu. Przedmiotem badań teorii ID są takie zjawiska przyrodnicze, o których można przypuszczać, że są skutkami działania inteligencji. Teoria ta jest w pewnym sensie tego słowa - opcją neutralną wobec naturalizmu i nadnaturalizmu.

Da się ona uzgodnić z naturalizmem (i jego światopoglądowymi konsekwencjami) wtedy, gdy przyjmie się, że wykrywane skutki działania inteligencji nie mają nadnaturalnej natury. Skutki te są efektem oddziaływania materialnych przyczyn, na przykład naturalnych, inteligentnych istot.

Da się również uzgodnić z nadnaturalizmem, gdy przyjmie się, że do wygenerowania złożoności i różnorodności świata przyrodniczego nie wystarczą procesy naturalne i musi wspomagać je wyższa, utożsamiana z Bogiem, inteligencja. Następstwem tego drugiego stanu rzeczy jest to, że dość powszechnie ID utożsamiana jest też z kreacjonizmem i jego światopoglądowymi konsekwencjami.

Wspomniane wyżej składniki światopoglądowe stanowią drugie (obok niewspółmierności) zasadnicze źródło konfliktu między odmiennymi EUO. Zaś ten ideologiczno-światopoglądowy konflikt prowadzi do, zachodzącej już, zmiany charakteru zachodniej cywilizacji z cywilizacji chrześcijańskiej na postchrześcijańską. U podstaw tej ostatniej tkwi nowy, ewolucyjny mit pochodzenia.

Naturalistyczne i antynaturalistyczne EUO tworzą poznawcze ramy dla uprawiania nauki, wskazując, w swoich obrębach, jakie rodzaje wyjaśnień są dopuszczalne, a jakie są zakazane. Zaś EUO naturalistycznego teizmu również tworzy taką ramę dla jej uprawiania. Tworzy też inną, specyficzną, bo światopoglądową ramę uprawiania nauki. Dzięki niej ma być możliwe zażegnanie kryzysu wiary wśród ludzi wykształconych, w szczególności naukowców. Kryzys ten jest następstwem niezgodności - dopuszczającego wyjaśnienia antynaturali- 
styczne - tradycyjnego teistycznego opisu świata oraz — zakazującego dopuszczania takich wyjaśnień — współczesnego naukowego opisu świata.

Teizm naturalistyczny rezygnuje z wyjaśnień antynaturalistycznych i nakazuje poszukiwania śladów Boskiej aktywności wyłącznie w sferze pozaempirycznej. Tę odmianę EUO określić można przez nakaz przyjmowania jedynie naturalistycznych wyjaśnień dla faktów i procesów, wraz z jednoczesnym zakazem przyjmowania wyjaśnień antynaturalistycznych, czyli wyjaśnień powołujących się na przyczyny nadnaturalne $i$ inteligentne. Zaś twarde jądro naturalistycznego teizmu sformułować można w następujący sposób: Bóg istnieje i jest immanentnie obecny w prawach przyrody (nie działa w przyrodzie w empirycznie wykrywalny sposób).

Drugim, po zażegnaniu kryzysu wiary, zadaniem stawianym tej odmianie EUO jest obrona cywilizacji chrześcijańskiej przed próbami przekształcenia ją w cywilizację postchrześcijańską. Obrona ta odbywać ma się drogą pogodzenia obrazu świata współczesnego przyrodoznawstwa z teizmem chrześcijańskim. Pogodzenie to odbywa się pod hasłem, w myśl którego Bóg prowadzi ewoluującą przyrodę ku swoim zamiarom. W zamierzeniu zwolenników teizmu naturalistycznego ma to być udana obrona naszej cywilizacji.

Wskazałem, że zarówno zażegnanie kryzysu wiary, jak i godzenie obrazu świata przyrodoznawstwa z teizmem odbywa się drogą „umiejętnego czytania” ksiąg Pisma Świętego, które polega na interpretacji Biblii przez pryzmat najnowszych osiągnięć nauki. Zaś takie „czytanie” ma olbrzymie koszty światopoglądowe i epistemiczne.

Te pierwsze sprowadzają się, najogólniej rzecz biorąc, do dostosowywania twierdzeń teologicznych do naukowego naturalizmu, co bardzo często prowadzi do poważnej reinterpretacji podstawowych elementów tradycyjnej wiary chrześcijańskiej (na przykład Bóg nie działa w przyrodzie w empirycznie wykrywalny sposób; nie istnieją cudy). De facto nie zadowala to nikogo — ani znakomitej większości uczonych, którzy nie akceptują ujęcia teistycznego, ani zwykłych chrześcijan, ponieważ jest to radykalne odstępstwo od podstawowych elementów ich wiary.

Na koszty epistemiczne ,umiejętnego czytania” ksiąg Biblii składa się szereg twierdzeń. Jednym z nich jest fałszywa konstatacja, w myśl której założenia 
tradycji judeochrześcijańskiej i współczesna biologia ewolucyjna są ze sobą zgodne. Nie są zgodne, gdyż postulowany przez naturalistycznych teistów obraz ewolucji, która dokonuje się drogą niewykrywalnych empirycznie boskich interwencji w przyrodzie, nie jest obrazem Darwinowskim, który wyklucza jakiekolwiek Boskie interwencje.

Innym takim kosztem są co najmniej dwa twierdzenia jawnie niezgodne z osiągnięciami współczesnej filozofii nauki. W myśl jednego z nich rozdzielność płaszczyzn nauki i religii jest „faktem dokonanym”. Pozwala to na uznawanie tezy, zgodnie z którą tam, gdzie nie sięga poznanie naukowe, rozpoczyna się obszar empirycznie niewykrywalnej działalności Boga. Jednakże współczesna filozofia nauki przekonująco wykazała, że ostre podziały kultury na naukę, filozofię, teologię i inne dziedziny mają charakter arbitralny, gdyż te dziedziny kultury wzajemnie się przenikają. Zgodnie $\mathrm{z}$ drugim $\mathrm{z}$ tych twierdzeń nauka rozwija się w sposób kumulatywny (naturalistyczni teiści odrzucają tezę o niewspółmierności teorii naukowych). Akceptacja kumulatywizmu umożliwia bowiem utrzymywanie tezy o dostosowywaniu Pisma Świętego do naukowego obrazu świata. Gdyby w następstwie pojawiających się niewspółmiernych teorii naukowych obraz świata ulegał radykalnym przeobrażeniom, to dopasowywanie Biblii do naukowego obrazu świata nie byłoby możliwe. Nieustannie należałoby metaforyczne reinterpretacje Biblii uzgadniać ze zmiennymi prawdami przyrodniczymi.

Jeszcze innym, w mojej opinii najważniejszym, epistemicznym kosztem akceptacji tego EUO jest to, że układ ten de facto ma dwie „święte księgi”. Jedna z nich jest „bardziej święta” lub „bardziej podstawowa” niż druga. To księga natury stanowi punkt odniesienia dla umiejętnego czytania drugiej, Pisma Świętego. Biblia, przy takim do niej podejściu, przekształciła się, w zredukowaną do postulatów etycznych księgę traktującą wyłącznie o wartościach moralnych i sensie życia. To jednak nie wszystko. Wartość tej księgi jest już kwestionowana. W opinii niektórych ewolucjonistów straciła ona swoją moc zewnętrznego źródła moralności.

Chciałbym w tym miejscu podziękować moim Kolegom: profesorom Kazimierzowi Jodkowskiemu i Piotrowi Bylicy oraz doktorowi Dariuszowi Saganowi za szereg cennych uwag do wstępnych wersji artykułów - poświęconych 
epistemicznym układom odniesienia - które następnie opublikowane zostały w Filozoficznych Aspektach Genezy.

Krzysztof J. Kilian

\section{Bibliografia}

AuI Ejaz, „Summary of Life Itself”, Eukaryon 2009, vol. 5, s. 17-18, https://tiny.pl/g279j (25.12.2018)

AlıFF John V., „Teaching Evolution and the Challenge of Intelligent Design: A Symposium”, Georgia Journal of Science 2005, vol. 63, no. 3, s. 144-152, https://tiny.pl/tqdkc (25.12.2018).

Amarasingam Amarnath (ed.), Religion and the New Atheism: A Critical Appraisal, Studies in Critical Social Sciences, vol. 25, Brill, Leiden, Boston 2010.

AnKerberg John i Weldon John, Fakty w sporze: stworzenie czy ewolucja? (z posłowiem Kazimierza Jodkowskiego), przeł. Mieczysław Pajewski, Wydawnictwo MEGAS, Warszawa 2003.

Ayala Francisco J., Dar Karola Darwina dla nauki i religii, przeł. Piotr Dawidowicz, Wydawnictwa Uniwersytetu Warszawskiego, Warszawa 2009.

Ayala Francisco J., „Darwin's Revolution”, w: CAmpBell and Schopf (eds.), Creative Evolution..., s. 1-18.

Ayala Francisco J., Cicerone Ralph J., Clegg M.T., Dalrymple G. Brent, Dickerson Richard E., Gould Stephen J., Herschbach Dudley R., Kennedy Donald, McInerney Joseph D., Moore John A., Ostriker Jeremiah P., Rupp George, Scott Eugenie, Schulz Barbara, and Stanley Steven M., Science and Creationism: A View from the National Academy of Sciences, National Academy Press, Washington, DC. 1999, https://tiny.pl/tq98f (23.12. 2018).

BAŁĘKOWSKI Krzysztof i MACIĄG Kamil (red.), Wybrane zagadnienia z filozofii języka i religii, Fundacja na rzecz promocji nauki i rozwoju TYGIEL, Lublin 2015.

Beскwith Francis J., Taking Rites Seriously: Law, Politics, and the Reasonableness of Faith, Cambridge University Press, New York 2015.

BeHE Michael J., „Filozoficzne zarzuty stawiane hipotezie inteligentnego projektu: odpowiedź na krytykę", przeł. Dariusz Sagan, Filozoficzne Aspekty Genezy 2004, t. 1, s. 115139, https://tiny.pl/gt9nw (27.12.2018). 
BEHE Michael J., „Nieredukowalna złożoność: problem dla ewolucjonizmu darwinowskiego”, przeł. Dariusz Sagan, Filozoficzne Aspekty Genezy 2005/2006, t. 2/3, s. 67-96, https:// tiny.pl/qzq8n (26.12.2018).

Berman Marshall, „Intelligent Design Creationism: A Threat to Society — Not Just Biology", The American Biology Teacher 2003, vol. 65, no. 9, s. 646-648, https://tiny.pl/g26n5 (25.10.2018).

Berra Tim M., Evolution and the Myth of Creationism: A Basic Guide to the Facts in the Evolution Debate, Stanford University Press, Stanford 1990.

BioLogos Editorial Team, „Does Intelligent Design Really Explain a Complex and Puzzling World?", The BioLogos 15 March 2010, https://tiny.pl/tqdz1 (26.12.2018).

BorczyK Bartosz, „Dlaczego teoria ewolucji jest ważna”, w: Krajna, Ryk i SuJAK-Lesz (red.), Problemy dydaktyki fizyki..., s. 89-115, https://tiny.pl/g262s (21.12.2018).

Brauer Matthew J., Forrest Barbara, and Gey Steven G., „Is It Science Yet?: Intelligent Design Creationism and the Constitution", Washington University Law Review 2005, vol. 83, no. 1, s. 1-150, https://tiny.pl/g2vm1 (25.12.2018).

Brooke John Hedley, „Karol Darwin o religii”, przeł. Dariusz Sagan, Filozoficzne Aspekty Genezy 2011, t. 8, s. 61-74, https://tiny.pl/xhnnn (22.12.2018).

BRookes John, „Science and Religion: Lessons from History?”, Science 1998, vol. 282, no. 5396, s. 1985-1986, https://tiny.pl/tqfnq (27.12.2018).

BrożeK Bartosz i MączKa Janusz (red.), Czy nauka zastąpi religię?, Copernicus Center Press, Kraków 2011.

Buckna David, „Do Creationists Publish in Notable Refereed Journals?”, Creation Ministries International April 1997, https://tiny.pl/tqrjs (26.12.2018).

ByLICA Piotr, „Bóg luk a granice nauki”, Referat wygłoszony na III Filozoficznym Forum Młodych, Lublin 2004, s. 1-12, https://tiny.pl/hdqgd (26.12.2018).

Bylica Piotr, „Darwin o celowości w przyrodzie”, Kwartalnik Historii Nauki i Techniki 2008, nr 3-4, s. 259-273, https://tiny.pl/q3mlc (27.12.2018).

BYLICA Piotr, „Darwinizm i koncepcja wieloświata a religijne wyjaśnienie racjonalnego porządku i poznawalności przyrody”, Zagadnienia Naukoznawstwa 2012, nr 3 (193) s. 185 204, https://tiny.pl/xhnlq (27.12.2018).

ByLICA Piotr, „Główne założenia i problemy teizmu naturalistycznego w sprawie relacji sfery nadprzyrodzonej i świata przyrodniczego", w: Dyk (red.), Sozologia systemowa. Tom IV..., s. 55-95, https://tiny.pl/q3m1d (26.12.2018). 
Bylica Piotr, „Kazimierza Jodkowskiego koncepcja epistemicznych układów odniesienia a teizm naturalistyczny Johna Polkinghorne'a”, w: Bylica, Kilian, Piotrowski i Sagan (red.), Filozofia — nauka - religia..., s. 191-211, https://tiny.pl/tqd37 (26.12.2018).

Bylica Piotr, „Konflikt między teizmem i nauką bazującą na naturalizmie - w ujęciu Phillipa E. Johnsona”, Zagadnienia Naukoznawstwa 2003, nr 3-4 (157-158), s. 227-238, https://tiny.pl/xh894 (27.12.2018).

ByLICA Piotr, „Mark Harris as a Naturalistic Theist: The Perspective of the Model of Levels of Analysis", Filozoficzne Aspekty Genezy 2015, t. 12, s. 7-36, https://tiny.pl/tqd38 (26.12. 2018).

BYLICA Piotr, „Nauka światopoglądowo neutralna?”, Fronda 2012, nr 63, s. 67-80, https:// tiny.pl/gkfxr (26.12.2018).

BYLICA Piotr, „NDE a empiryczność argumentów na rzecz tezy o dualizmie duszy i ciała w kontekście relacji nauki i religii”, w: DYK (red.), Sozologia systemowa. Tom VI..., s. 91-132, https://tiny.pl/tqd3p (26.12.2018).

Bylica Piotr, „NOMA as the Cure for Conflict Between Science and Religion: Reply to Ludwik Kowalski's Commentary on the NOMA Principle", Filozoficzne Aspekty Genezy 2014, t. 11, s. 29-34, https://tiny.pl/tq5v2 (28.12.2018).

BYLICA Piotr, „Testowalność teorii inteligentnego projektu”, Filozofia Nauki 2003, nr 2 (42), s. 41-49, https://tiny.pl/q3m11 (25.12.2018).

ByLicA Piotr, „Wątki antyantropocentryzmu i ekologizmu w tekstach teistów naturalistycznych — z punktu widzenia modelu poziomów analizy", w: Dyк, SKRzypczak i Dyк (red.), Sozologia systemowa. Tom VIII..., s. 11-31.

Bylica Piotr, „Wpływ teizmu chrześcijańskiego na rozumienie nauki oraz relacji między sferą przyrodniczą i nadprzyrodzoną w okresie rewolucji naukowej XVI-XVII w. a teza o wrodzonym konflikcie między nauką a religią", Kwartalnik Historii Nauki i Techniki 2013, nr 1, s. 73-90, https://tiny.pl/xhnln (27.12.2018).

BYLICA Piotr, Współczesny teizm naturalistyczny z punktu widzenia modelu poziomów analizy. Problem dzialania sfery nadnaturalnej w przyrodzie, Biblioteka Filozoficznych Aspektów Genezy, t. 7, Instytut Filozofii Uniwersytetu Zielonogórskiego, Zielona Góra 2016, https://tiny.pl/gkdv1 (21.12.2018).

ByLICA Piotr, „Zarys modelu poziomów analizy w badaniach relacji nauki i religii”, Filozoficzne Aspekty Genezy 2012, t. 9, s. 221-253, https://tiny.pl/xhzml (26.12.2018).

Bylica Piotr, Gazda Małgorzata, Jodkowski Kazimierz, Kilian Krzysztof J. i Sagan Dariusz, „Dyskusja nad artykułem Adama Trybusa, «Program badawczy SETI a teoria inteligentnego projektu»”, Filozoficzne Aspekty Genezy 2016, t. 13, s. 211-242, https://tiny.pl/g8 nvh (25.12.2018). 
Bylica Piotr, Jodkowski Kazimierz, Kilian Krzysztof J. i Sagan Dariusz, „Dyskusja nad artykułem Adama Groblera, «Słabości eksplanacyjne teorii inteligentnego projektu»”, Filozoficzne Aspekty Genezy 2013, t. 10, s. 17-63, https://tiny.pl/q3m1m (22.12.2018).

Bylica Piotr, Kilian Krzysztof J., Piotrowski Robert i Sagan Dariusz (red.), Filozofia nauka - religia. Ksiega jubileuszowa dedykowana Profesorowi Kazimierzowi Jodkowskiemu z okazji 40-lecia pracy naukowej, Oficyna Wydawnicza Uniwersytetu Zielonogórskiego, Zielona Góra 2015.

Bylica Piotr, Kidian Krzysztof J. i Sagan Dariusz, „Wstęp”, w: Bylica, Kitian, Piotrowski i SAGAN (red.), Filozofia - nauka - religia..., s. 11-33, https://tiny.pl/tqd3k (26.12. 2018).

Bylica Piotr and Sagan Dariusz, „God, Design, and Naturalism: Implications of Methodological Naturalism in Science for Science-Religion Relation”, Pensamiento 2008, vol. 64, núm. 242, s. 621-638, https://tiny.pl/g2884 (23.12.2018).

CAMP Robert, „Czy teoria inteligentnego projektu może być naukowa w tym samym sensie, co program SETI?", przeł. Piotr Wołkowski, Filozoficzne Aspekty Genezy 2009/2010, t. 6/7, s. 161-173, https://tiny.pl/xh8hl (26.12.2018).

CAmpbell John H. and Schopf J.W. (eds.), Creative Evolution!?, Jones and Bartlett, New York 1994.

CARlisle Christopher, „Interview with Dr. Michael Ruse, Ph.D.”, w: CARlisle and Smith, The Complete Idiot's Guide..., s. 275-290.

Carlisle Christopher, M. Div. and Smith W. Thomas Jr., The Complete Idiot's Guide to Understanding Intelligent Design, Penguin Group, New York 2006.

Chaberek Michał OP, „Czy Bóg mógł się posłużyć ewolucją?”, Fronda 2012, nr 63, s. 83103.

CHABEREK Michał OP, ,Neodarwinizm skończy jak marksizm. Rozmowa z Jay’em W. Richardsem", Fronda 2012, nr 63, s. 43-47.

Chaberek Michał OP, „Św. Tomasz z Akwinu a ewolucjonizm. Polemika z tezami Piotra Lichacza OP i Williama E. Carrolla”, Filozoficzne Aspekty Genezy 2012, t. 9, s. 33-52, https://tiny.pl/xhnqc (27.12.2018).

Chaberek Michał OP, „Wykrywanie informacji w komórce. Rozmowa ze Stephenem C. Meyerem", Fronda 2012, nr 63, s. 105-110.

Снолескі Pawel, „O co tyle szumu?”, Idź Pod Prąd 2007, nr 11 (40), s. 8, https://tiny.pl/tq5 ds (28.12.2018).

Chudziński Wojciech i Ryвicka Dorota, „Mózg a świadomość - wywiad z prof. Johnem Ecclesem", opracowanie na podstawie Paris Match, infra.org.pl 24 lipca 2012, https://tiny. $\mathrm{pl} / \mathrm{g} 8 \mathrm{zc} 3(23.12 .2018)$. 
Clarke Steve, „Naturalism, Science and the Supernatural”, Sophia. International Journal of Philosophy and Traditions 2009, vol. 48, s. 127-142.

Colodny Robert G. (ed.), Beyond the Edge of Certainty: Essays in Contemporary Science and Philosophy, Prentice-Hall, Englewood Cliffs, New Jersey 1965.

Coyne George V. SJ, „Przypadek jako metoda Boskiego stwarzania”, przeł. Dariusz Sagan, Filozoficzne Aspekty Genezy 2005/2006, t. 2/3, s. 39-44, https://tiny.pl/xhkgd (27.12.2018).

Coyne Jerry A., Ewolucja jest faktem, przeł. Marcin Ryszkiewicz i Wiesław Studencki, Na Ścieżkach Nauki, Prószyński i S-ka, Warszawa 2009.

Coyne Jerry A., „Science, Religion, and Society: The Problem of Evolution in America”, Evolution. International Journal of Organic Evolution 2012, vol. 66, no. 8, s. 2654-2663, https://tiny.pl/thtdt (26.12.2018).

CRICK Francis, Life Itself: Its Origin and Nature, Simon \& Schuster, New York 1981.

CSSHS Editorial Staff, A Creation Course - In 13 Lessons, Creation Social Science and Humanities Society. Quarterly Journal 1990, vol. 12. no. 1.

CSSHS Editorial Staff, „Lesson 1. Creation, the Foundation of the Biblical World View”, w: CSSHS Editorial Staff, A Creation Course..., s. 2-7, wersja elektroniczna bez numerów stron: https://tiny.pl/th318 (12.12.2018).

CSSHS Editorial Staff, „Lesson 3. Evolutionism”, w: CSSHS Editorial Staff, A Creation Course..., s. 14-19, wersja elektroniczna bez numerów stron: https://tiny.pl/th315 (23.12. 2018).

CSSHS Editorial Staff, „Lesson 7. Mans's Creativity: Science”, w: CSSHS Editorial Staff, A Creation Course..., s. 33-38, wersja elektroniczna bez numerów stron: https://tiny.pl/th 34w (12.12.2018).

DARwIN Charles, The Life and Letters of Charles Darwin. Volume II Including an Autobiographical Chapter, Edited by his Son Francis Darwin, William Clowes and Sons, Limited, London 1887, https://tiny.pl/tq59n (27.12.2018).

DARwIN Karol, Dziela wybrane. Autobiografia i wybór listów, t. 8, przeł. A. Iwanowska, A. Krasicka, J. Połtowicz i S. Skowron, Państwowe Wydawnictwo Rolnicze i Leśne, Warszawa 1960 .

Davies Paul, „Fizyka i umysł Boga. Przemówienie na uroczystości wręczenia Nagrody Templetona", przeł. Joanna Popek, Filozoficzne Aspekty Genezy 2011, t. 8, s. 7-21, https://ti ny.pl/xhnlk (27.12.2018).

DAwkins Richard, Bóg urojony, przeł. Piotr Szwajcer, Wydawnictwo CiS, Warszawa 2007. 
DAwkins Richard, „Czy nauka jest religią?”, przeł. Ziemowit Ciuraj, Racjonalista 3 grudnia 2012, https://tiny.pl/tqwp9 (22.12.2018).

DAwKINS Richard, Rzeka genów. Darwinowski obraz życia, przeł. Marek Jannasz, Oficyna Wydawnicza MOST, Warszawa 1995.

DAwkins Richard, Samolubny gen, przeł. Marek Skoneczny, Prószyński i S-ka, Warszawa 1996.

DAwKINS Richard, Ślepy zegarmistrz, czyli jak ewolucja dowodzi, że świat nie zostal zaplanowany, przeł. Antoni Hoffman, Biblioteka Myśli Współczesnej, Państwowy Instytut Wydawniczy, Warszawa 1994.

Dę̧owski Józef i Hetmański Marek (red.), Poznanie. Człowiek. Wartości. Prace ofiarowane Profesorowi Zdzislawowi Cackowskiemu, Wydawnictwo UMCS, Lublin 2000.

Dębowski Józef i Starzyńska-Kościuszko Ewa (red.), Nauka. Racjonalność. Realizm. Między filozofią przyrody a filozofią nauki i socjologią wiedzy, Instytut Filozofii Uniwersytetu Warmińsko-Mazurskiego w Olsztynie, Olsztyn 2013.

Delfino Robert A., „Naturalizm metodologiczny i ewolucja”, przeł. Rafał Lizut, w: JAROSZYŃSKI (red.), Ewolucjonizm czy kreacjonizm..., s. 137-156, https://tiny.pl/gzj7b (27.12. 2018).

Dembski William A., „Odmiany naturalizmu. Czy któraś forma naturalizmu jest zgodna z teorią inteligentnego projektu?", przeł. Dariusz Sagan, Na Poczatku ... 2005, nr 1-2, s. $45-$ 54, https://tiny.pl/xhkg8 (27.12.2018).

Dembsкi William A., „Powrót projektu do nauk przyrodniczych”, przeł. Dariusz Sagan, $\mathrm{Na}$ Poczatku... 2004, nr 9-10 (185-186), s. 323-342, https://tiny.pl/thmgz (26.12.2018).

Dembski William A., „Śmierć i Upadek: dlaczego teistyczny ewolucjonizm nie łagodzi problemu zła”, przeł. Dariusz Sagan, Filozoficzne Aspekty Genezy 2013, t. 10, s. 159-176, https://tiny.pl/xh2nj (27.12.2018).

Dembski William A., „Tematy badań w ramach teorii inteligentnego projektu”, przeł. Dariusz Sagan, Na Poczatku ... 2005, nr 3-4 (192-193), s. 136-146, https://tiny.pl/xhzw3 (26. 12.2018).

Dembski William A. and W derstand Guide to the Controversy, InterVarsity Press, Downers Grove, Illinois 2010.

Denton Michael J., Evolution: A Theory in Crisis, Burnett Books, London 1985.

Denton Michael J., „Miejsce życia i człowieka w przyrodzie. Obrona tezy antropocentrycznej”, przeł. Dariusz Sagan, Filozoficzne Aspekty Genezy 2015, t. 12, s. 209-254, https://tiny. pl/gfjgx (14.12.2018).

Dilthey Wilhelm, „O istocie filozofii”, w: Dilthey, O istocie filozofii..., s. 3-112. 
Ditтhey Wilhelm, $\mathbf{O}$ istocie filozofii i inne pisma, przeł. Elżbieta Paczkowska-Łagowska, Biblioteka Klasyków Filozofii, PWN, Warszawa 1987.

Duncan Richard F., ,Review of Reason in the Balance: The Case against Naturalism in Science, Law and Education, by Philip E. Johnson. Downers Grove, Ill.: InterVarsity Press, 1995", Journal of Law and Religion 2001, vol. 16, no 2, s. 945-949, https://tiny.pl/tq wlj (23.12.2018).

Dүк Wiesław (red.), Sozologia systemowa. Tom IV. Biosfera. Czlowiek i jego środowisko $\mathrm{w}$ aspekcie przyrodniczym, filozoficznym i teologicznym, Wydawnictwo Naukowe Uniwersytetu Szczecińskiego, Szczecin 2012.

Dүк Wiesław (red.), Sozologia systemowa. Tom VI. Noosfera. Czlowiek i jego środowisko w aspekcie przyrodniczym, filozoficznym i teologicznym, Wydawnictwo Naukowe Uniwersytetu Szczecińskiego, Szczecin 2014

Dyk Wiesław, Skrzypczak Wiesław i Dyк Tadeusz (red.), Sozologia systemowa. Tom VIII. Kosmosfera. Żywa planeta w oceanie Wszechświata: Czlowiek i jego środowisko w aspekcie przyrodniczym, filozoficznym i teologicznym, Wydawnictwo Naukowe Uniwersytetu Szczecińskiego, Szczecin 2016.

EDIs Taner, „Dlaczego «teoria inteligentnego projektu» jest bardziej interesująca niż tradycyjny kreacjonizm”, przeł. Dariusz Sagan, Filozoficzne Aspekty Genezy 2007/2008, t. 6/7, s. 81-93, https://tiny.pl/xh8mc (25.12.2018).

ELIADE Mircea, Aspekty mitu, przeł. Piotr Mrówczyński, Wydawnictwo KR, Warszawa 1998.

ELIADE Mircea, W poszukiwaniu historii i znaczenia religii, przeł. Agnieszka Grzybek, Wydawnictwo KR, Warszawa 1997.

FarRell John, „It's Time to Retire «Theistic Evolution»”, Forbes 19 March 2016, https://ti ny.pl/tq591 (27.12.2018).

FeYerabend Paul K., Jak być dobrym empirystą, przeł. Krystyna Zamiara, Państwowe Wydawnictwo Naukowe, Warszawa 1979.

Feyerabend Paul K., „Krytyka naukowego rozumu”, przeł. Edmund Mokrzycki, w: МoKRZYCKI (red.), Racjonalność a styl myślenia..., s. 167-217.

Feyerabend Paul K., „Problems of Empiricism”, w: Colodny (ed.), Beyond the Edge of Certainty..., s. 145-260.

Feyerabend Paul K., „Wyjaśnianie, redukcja i empiryzm”, w: Feyerabend, Jak być dobrym empirystą..., s. 62-151.

FisHeR Ian, „Professor-Turned-Pope Leads a Seminar on Evolution”, New York Times 2 September 2006, https://tiny.pl/gkf7n (25.12.2018). 
Florek-Moskal Monika, „Wszechświat jest twórczy, choć nieprzewidywalny. Rozmowa z ks. prof. Michałem Hellerem, kosmologiem, filozofem, fizykiem i teologiem, laureatem Nagrody Templetona (2008)", Wprost 2010, nr 1/2, https://tiny.pl/tqfkg (27.12.2018).

Forrest Barbara C., „Inside Creationism's Trojan Horse: A Closer Look at Intelligent Design", Georgia Journal of Science 2005, vol. 63, no. 3, s. 153-166, https://tiny.pl/g2vmk (25.12.2018).

Fuller Steve, „What Has Atheism Ever Done for Science?”, w: Amarasingam (ed.), Religion and the New Atheism..., s. 57-78.

GAzDA Małgorzata, „Ban na inteligentny projekt”, Idź Pod Prąd 2016, nr 3-5 (139-141), s. 10, https://tiny.pl/tqdzc (26.12.2018).

GAzDa Małgorzata, „Dobór — ale czy naturalny?”, Idź Pod Prąd 2015/2016, nr 12-1 (137138), s. 9-10, https://tiny.pl/tqdzd (26.12.2018).

GAzDA Małgorzata, „Pochodzenie życia. Krytyka teorii świata RNA w świetle badań laboratoryjnych dotyczących nieenzymatycznej syntezy rybonukleotydów”, Filozofia Nauki 2015, nr 3 (91), s. 113-131, https://tiny.pl/tqwns (21.12.2018).

GAzDA Małgorzata, „Stephena C. Meyera koncepcja «podpisu w komórce» a filozoficzne podstawy nauki”, Filozoficzne Aspekty Genezy 2016, t. 13, s. 7-23, https://tiny.pl/g16kj (26. 12.2018).

GAzDA Małgorzata, „Zasada naturalizmu metodologicznego czy adekwatności przyczynowej?”, Idź Pod Prąd 2015, nr 10-11 (135-136), s. 8-9, https://tiny.pl/tqdbj (26.12.2018).

Gilchrist George W., „The Elusive Scientific Basis of Intelligent Design Theory”, Reports of the National Center for Science Education 1997, vol. 17, no. 3, s. 14-15, https://tiny.pl/tq $\operatorname{dzm}(26.12 .2018)$.

Goodenough Ursula, „Are You a Religious Naturalist Without Knowing It?”, National Public Radio. Cosmos and Culture. Commentary on Science and Society 29 January 2010, https://tiny.pl/tqfkx (27.12.2018).

Goodenough Ursula, „Who Is a Religious Naturalist?”, Theology and Science 2017, vol. 15 , no.3, s. 231-234.

Gould Stephen Jay, „Epizodyczny charakter zmian ewolucyjnych”, w: Gould, Niewczesny pogrzeb Darwina..., s. 183-200.

Gould Stephen Jay, Niewczesny pogrzeb Darwina. Wybór esejów, przeł. Nina Kancewicz-Hoffman, Biblioteka Myśli Wspótczesnej, Państwowy Instytut Wydawniczy, Warszawa 1991.

Gould Stephen Jay, „Nonoverlapping Magisteria”, Filozoficzne Aspekty Genezy 2014, t. 11, s. 7-21, https://tiny.pl/tq5c4 (28.12.2018). 
Gregory Brad S., „No Room for God?: History, Science, Metaphysics, and the Study of Religion", History and Theory 2008, vol. 47, no. 4, s. 495-519, https://tiny.pl/tqfv7 (27.12. 2018).

GribBin Alice, „Preview: The Four Horsemen of New Atheism Reunited”, NewStatesman 22 December 2011, https://tiny.pl/tqwph (22.12.2018).

Grobler Adam, „Słabości eksplanacyjne teorii inteligentnego projektu”, Filozoficzne Aspekty Genezy 2013, t. 10, s. 7-16, https://tiny.pl/xh8ls (22.12.2018).

GromadzKi Robert, „Zmierzch cywilizacji Zachodu. Rozmowa z profesorami Kazimierzem Jodkowskim i Wojciechem Sadym, filozofami w Uniwersytecie Zielonogórskim”, Gazeta Lubuska 29-30 grudnia 2001, nr 303 (15314), s. 13, https://tiny.pl/tqwj1 (22.12.2018).

Gutowski Piotr, „Czym jest «nowy ateizm»?”, w: SŁoмка (red.), Nauki przyrodnicze..., s. 7-45, https://tiny.pl/tqwpx (28.12.2018).

Haldane John B.S., Fact and Faith, Watts \& Company, London 1934.

Hall A. Rupert, Rewolucja naukowa 1500-1800. Ksztaltowanie się nowożytnej postawy naukowej, przeł. Tadeusz Zembrzuski, Instytut Wydawniczy PAX, Warszawa 1966.

Heller (Michał) Michael, „Chaos, Probability, and the Comprehensibility of the World”, w: Heller, Creative Tension..., s. 127-143, https://tiny.pl/tq2rp (26.12.2018).

Heller Michał, „Chrześcijański naturalizm”, Roczniki Filozoficzne 2003, t. 51, nr 3, s. 4158, https://tiny.pl/tq2q2 (26.12.2018).

Heller (Michał) Michael, Creative Tension: Essays on Science and Religion, Templeton Foundation Press, West Conshohocken, Pennsylvania 2003.

Heller Michał, „Konieczność i przypadek w ewolucji Wszechświata”, Zagadnienia Filozoficzne w Nauce 2009, vol. 44, s. 3-12, https://tiny.pl/g2vml (25.12.2018).

Heller Michał, „Nie za bardzo inteligentny projekt”, Copernicus Center 24 grudnia 2014, https://iny.pl/gzj65 (26.12.2018).

Heller Michał, Nowa fizyka i nowa teologia, Biblos, Tarnów 1992.

Heller Michał, „Rzeczy najważniejsze” (Przemówienie wygłoszone przez ks. Michała Hellera 12 marca 2008 r. w Nowym Jorku z okazji przyznania mu Nagrody Templetona), w: Brożé i Mączka (red.), Czy nauka zastąpi religię..., s. 11-14.

Heller Michał, Sens życia i sens Wszechświata. Studia z teologii wspólczesnej, Biblos, Tarnów 2002

HeLler Michał, Usprawiedliwienie Wszechświata, Społeczny Instytut Wydawniczy Znak, Kraków 1984. 
Heller Michał, Wszechświat i Słowo, Społeczny Instytut Wydawniczy Znak, Kraków 1981.

Heller Michał, KwiAtex Łukasz i HoHol Mateusz, „,Wielka Matryca i herezja Inteligentnego Projektu — rozmowa z Michałem Hellerem”, Nauka i Religia.PL 12 stycznia 2013, https://tiny.pl/tqdkq (25.12.2018).

HILBERT Martin, „Darwinowskie podziały. Papież, kardynał, jezuita i ewoluująca debata nad pochodzeniem", przeł. Dariusz Sagan, Filozoficzne Aspekty Genezy 2005/2006, t. 2/3, s. 45-63, https://tiny.pl/gzj8m (27.12.2018).

HoDGe Geoffrey Lee, „Advancing the Atheist Movement: Dawkins, Dennett, and the Second Wave", TheHumanist.com 19 June 2015, https://tiny.pl/g266t (22.12.2018).

Ноноц Mateusz, „Darwin jako przebrany za wroga przyjaciel religii”, Zagadnienia Filozoficzne w Nauce 2010, vol. 47, s. 161-165, https://tiny.pl/tqdk4 (25.12.2018).

HoyLe Fred, Matematyka ewolucji, przeł. Robert Piotrowski, Wydawnictwo MEGAS, Warszawa 2003.

Hoyle Fred and Wickramasinghe Nalin Chandra, Evolution from Space: A Theory of Cosmic Creationism, Simon \& Schuster, Inc., New York 1984.

HunTeR Cornelius G., „Dlaczego teoria ewolucji nie spełnia kryterium naukowości”, przeł. Izabela Janus, Filozoficzne Aspekty Genezy 2012, t. 9, s. 53-78, https://tiny.p1/xh2p2 (18.12. 2018).

International Theological Commission, „Communion and Stewardship: Human Persons Created in the Image of God", https://tiny.pl/tt5dp (28.12.2018).

IsAAC Randy, „Od luk w wiedzy do wniosku o istnieniu Boga”, przeł. Małgorzata Gazda, Filozoficzne Aspekty Genezy 2012, t. 9, s. 187-198, https://tiny.pl/xhzmp (27.12.2018).

Janeczek Stanisław, Starościc Anna, Dąbek Dariusz i Herda Justyna (red.), Filozofia przyrody, Dydaktyka Filozofii, t. 3, Wydawnictwo Katolickiego Uniwersytetu Lubelskiego, Lublin 2013.

JAROSZYŃSKI Piotr (red.), Ewolucjonizm czy kreacjonizm, Przyszlość Cywilizacji Zachodu, Fundacja „Lubelska Szkoła Filozofii Chrześcijańskiej”, Lublin 2008.

JodKowski Kazimierz, „Antynaturalizm teorii inteligentnego projektu”, Roczniki Filozoficzne 2006, t. 54, nr 2, s. 63-76, https://tiny.pl/qzq86 (22.12.2018).

JoDкоwsкi Kazimierz (red.), Czy sprzeczność może być racjonalna?, Realizm. Racjonalność. Relatywizm, t. 4, Wydawnictwo UMCS, Lublin 1986.

JoDKоwSKı Kazimierz, „Czy teoria inteligentnego projektu posiada konsekwencje, dotyczące istnienia nadnaturalnego projektanta? Polemika z Elliottem Soberem", Filozoficzne Aspekty Genezy 2007/2008, t. 6/7, s. 41-49, https://tiny.pl/tqwn3 (22.12.2018). 
JoDKоwsкı Kazimierz, „Darwinowska teoria ewolucji jako teoria filozoficzna”, w: KonstańCZAK i TURowsKI (red.), Filozofia jako mądrość bycia..., s. 17-23, https://tiny.pl/q3m56 (21.12.2018).

JodKowski Kazimierz, „Dlaczego ewolucjonizm prowadzi do ateizmu?”, w: DЕ̨вowsKı i Hetmański (red.), Poznanie..., s. 65-76, https://tiny.pl/tq92w (18.12.2018).

JoDKowski Kazimierz, „Epistemiczne układy odniesienia i «warunek Jodkowskiego»”, w: Latawiec i Bugajak (red.), Filozoficzne..., s. 108-123, https://tiny.pl/g28sn (21.12.2018).

JoDкоwsкi Kazimierz, „Epistemiczny układ odniesienia teorii inteligentnego projektu”, $F i$ lozofia Nauki 2006, nr 1 (53), s. 95-105, https://tiny.pl/q3m5n (29.12.2018).

JoDKошsк Kazimierz, „Eskapizm teologii i filozofii katolickiej w sprawie «nauka a religia»", Na Poczatku ... 2005, nr 7-8 (196-197), s. 261-284, https://tiny.pl/gztl8 (23.12.2018).

JoDKowsкi Kazimierz, „Ewolucja ewolucjonizmu z popperowskiego punktu widzenia”, $F i$ lozofia Nauki 2003, nr 2 (42), s. 51-63, https://tiny.pl/tqwj9 (22.12.2018).

Jodкоwsкi Kazimierz, „Filozofia nauki Paula K. Feyerabenda. Stadium umiarkowane”, Studia Filozoficzne 1979, $\mathrm{nr} 11$ (168), s. 59-75.

Jodкоwsкi Kazimierz, „Filozofia przyrody a nauki przyrodnicze”, Colloquia Communia 2007, 1-2 (82-83), s. 15-22.

Jodkowski Kazimierz, „Fred Hoyle (1915-2010)”, w: Hoyle, Matematyka ewolucji..., s. 25-36, https://tiny.pl/gsxrw (25.12.2018).

JoDKowski Kazimierz, „Klasyfikacja stanowisk kreacjonistycznych”, Filozoficzne Aspekty Genezy 2005/2006, t. 2/3, s. 241-269, https://tiny.pl/q3m54 (25.12.2018).

JoDKowsкı Kazimierz, „Konflikt nauka-religia a teoria inteligentnego projektu”, w: JoDкошSкі (red.), Teoria inteligentnego projektu..., s. 145-180, https://tiny.pl/qzq8f (28.12. 2018).

JoDKowsкı Kazimierz, „Kreacjonizm a naturalizm nauk przyrodniczych”, Annales Universitatis Mariae Curie-Skłodowska, Sectio I, Lublin-Polonia 1996/1997, vol. 21-22, s. 11-26, https://tiny.pl/gkfx4 (26.12.2018).

JoDKowski Kazimierz, „Kreacjonizm młodej Ziemi a koncepcja Big Bangu. Poglądy Johna Hartnetta z konstruktywistycznej i eksternalistycznej perspektywy", Filozoficzne Aspekty Genezy 2015, t. 12, s. 37-79, https://tiny.pl/gs8k7 (22.12.2018).

JoDKowsкi Kazimierz, „Metafizyczne opowieści nauki jako fundament pluralizmu naukowego", w: JoHNsON, Wielka metafizyczna opowieść nauki..., s. 74-85, https://tiny.pl/q3m $5 \mathrm{p}(29.12 .2018)$.

JoDKоWSKI Kazimierz, Metodologiczne aspekty kontrowersji ewolucjonizm-kreacjonizm, Realizm. Racjonalność. Relatywizm, t. 35, Wydawnictwo UMCS, Lublin 1998. 
JoDкошsкі Kazimierz, „Nauka a religia”, Filozofia Nauki 2006, nr 1 (53), s. 31-32, https://ti ny.pl/g268c (22.12.2018).

Jodкоwsкi Kazimierz, „Nauka w oczach Feyerabenda”, w: Jodкоwsкi (red.), Czy sprzeczność..., s. 227-270.

JodKowski Kazimierz, „Nienaukowy fundament nauki”, w: PIETRZAK (red.), Granice nauki..., s. 59-108, https://tiny.pl/q3m1q (21.12.2018).

JodKowski Kazimierz, „NOMA, cudy i filtr eksplanacyjny”, Roczniki Filozoficzne 2005, t. 53, nr 2, s. 83-103, https://tiny.pl/tq5cj (28.12.2018).

Jodкowski Kazimierz, „O twardym jądrze ewolucjonizmu”, Problemy Genezy 2015, t. 23, s. 131-192.

JoDKоwSкI Kazimierz, „Od krytycznego racjonalizmu do anarchizmu metodologicznego”, w: ZachariasZ (red.), Profile racjonalności..., s. 135-158.

JodKowski Kazimierz, „Poglądy teologiczne Darwina”, w: Leszczyński (red.), Ewolucja. Filozofia. Religia..., s. 59-84, https://tiny.pl/q3m5z (23.12.2018).

JoDKowsкi Kazimierz, „Ruch kreacjonistyczny jest elementem pluralizmu naukowego”, Przeglad Filozoficzny - Nowa Seria 2001, nr 1 (37), s. 241-253, https://tiny.pl/gdw95 (22. 12.2018).

JoDкоwsкi Kazimierz, „Ślepy zegarmistrz”, w: JoDкоwsкı, Metodologiczne aspekty..., s. 351-369, https://tiny.pl/tqd3f (26.12.2018).

JoDKowski Kazimierz, Spór ewolucjonizmu z kreacjonizmem. Podstawowe pojęcia i poglądy, Biblioteka Filozoficznych Aspektów Genezy, t. 1, Wydawnictwo MEGAS, Warszawa 2007, https://tiny.pl/qzq8j (27.12.2018).

JoDKowsкi Kazimierz (red.), Teoria inteligentnego projektu — nowe rozumienie naukowości?, Biblioteka Filozoficznych Aspektów Genezy, t. 2, Wydawnictwo MEGAS, Warszawa 2007.

JodKowski Kazimierz, „Twarde jądro ewolucjonizmu”, Roczniki Filozoficzne 2003, t. 51, z. 3, s. 77-117, https://tiny.pl/q3m5j (29.12.2018).

JoDкоwsкi Kazimierz, „Uczony w ciemnym budynku. Na marginesie metafory Elżbiety Kałuszyńskiej”, w: Dębowski i StarzyńsKa-Kościuszko (red.), Nauka. Racjonalność. Realizm..., s. 55-67, https://tiny.pl/q3m1x (21.12.2018).

JoDKоwSкı Kazimierz, „Wstęp do teorii inteligentnego projektu”, Fronda 2012, nr 63, s. 1632, https://tiny.pl/gkfbn (23.12.2018).

JoDKоwSкı Kazimierz, „Z jakim relatywizmem bezskutecznie walczy Wojciech Sady? (Głos w dyskusji)", w: POMORSKI (red.), Wartość relatywizmu..., s. 123-146. 
JoDкошsк Kazimierz, „Zasadnicza nierozstrzygalność sporu ewolucjonizm-kreacjonizm”, Przeglad Filozoficzny - Nowa Seria 2012, nr 3 (83), s. 201-222, https://tiny.pl/gkfxn (21. 12.2018).

Johnson Bill, „Czy darwinizm ma ateistyczny charakter? Analiza przekonań i czynów Karola Darwina", przeł. Dariusz Sagan, Filozoficzne Aspekty Genezy 2011, t. 8, s. 75-91, https://tiny.pl/xhnk4 (23.12.2018).

Johnson George, „A Free-for-All on Science and Religion”, The New York Times 21 November 2006, https://tiny.pl/thksh (15.12.2018).

Johnson Phillip E., „Creator or Blind Watchmaker”, First Things January 1993, https://ti ny.pl/tt59k (27.12.2018).

Johnson Phillip E., „Głośna «herezja» w świątyni Darwina”, przeł. Kazimierz Jodkowski, w: JoDкошsкI, Metodologiczne aspekty..., s. 473-481, https://tiny.pl/tqdzv (26.12.2018).

Johnson Phillip E., „Reguły rozumowania darwinizmu”, w: Jodкоwsкi, Metodologiczne aspekty..., s. 460-472, https://tiny.pl/tqwn7 (21.12.2018).

Johnson Phillip E., Wielka metafizyczna opowieść nauki (z posłowiem Kazimierza Jodkowskiego), przeł. Piotr Bylica, Archiwum Na Poczatku..., z. 13, Polskie Towarzystwo Kreacjonistyczne, Warszawa 2003.

Kenyon Dean H., „Kreacjonistyczne ujęcie pochodzenia życia”, przeł. Kazimierz Jodkowski, w: JoDкошsкI, Metodologiczne aspekty..., s. 482-495, https://tiny.pl/qm4xj (25.12. 2018).

Kilian Krzysztof J., „Czym są epistemiczne układy odniesienia?”, Filozoficzne Aspekty Genezy 2017, t. 14, s. 191-236, https://tiny.pl/g8xqp (23.12.2018).

KILIAN Krzysztof J., „Epistemiczne układy odniesienia a problem interteoretycznej niewspółmierności - część 1", Filozoficzne Aspekty Genezy 2017, t. 14, s. 237-280, https://ti ny.pl/gzx3s (28.12.2018).

KitIan Krzysztof J., „Epistemiczne układy odniesienia a problem interteoretycznej niewspółmierności - część 2", Filozoficzne Aspekty Genezy 2017, t. 14, s. 281-325, https://ti ny.pl/gzx3v (28.12.2018).

KILIAN Krzysztof J., „Geneza idei epistemicznych układów odniesienia i ich odmiany”, Filozoficzne Aspekty Genezy 2017, t. 14, s. 137-190, https://tiny.pl/gzx34 (23.12.2018).

Kilian Krzysztof J., Poglądy filozoficzne Paula K. Feyerabenda. Część I. Program metodologiczny, Oficyna Wydawnicza Uniwersytetu Zielonogórskiego, Zielona Góra 2014.

Kilian Krzysztof J., „Wzrost wiedzy a zasada tolerancji”, w: Michalczenia, MizińsKa i OssowsKa (red.), Poszukiwania filozoficzne..., s. 155-173, https://tiny.pl/xhzfq (22.12.2018). 
KoJonen Erkki V.R., „Methodological Naturalism and the Truth Seeking Objection”, International Journal for Philosophy of Religion 2016, vol. 79, no. 3, s. 1-26, https://tiny.pl/gk fxk (12.10.2018).

KoJonen Erkki V.R., „The God of the Gaps, Natural Theology and Intelligent Design”, Journal of Analytic Theology 2016, vol. 4, s. 291-316, https://tiny.pl/tqf6r (27.12.2018).

Konstańczak Stefan i Turowski Tomasz (red.), Filozofia jako mądrość bycia, Oficyna Wydawnicza Uniwersytetu Zielonogórskiego, Zielona Góra 2009.

Kopeć Radosław i Chолескі Paweł, „Wywiad z prof. Jodkowskim”, Idź Pod Prąd 2007, nr 11 (40), s. 8, 11, https://tiny.pl/tq5ds (28.12.2018).

Котошıсz Wojciech, „Józefa Życińskiego meta-przedmiotowe ujęcie relacji między nauką a religią", Roczniki Filozoficzne 2012, t. 60, z. 4, s. 249-260, https://tiny.pl/tqfh3 (26.12. 2018).

Kowalski-Glikman Jerzy, „Bezradność postępowego inteligenta”, Świat Nauki 2008, nr 2 (198), s. 84-85, https://tiny.pl/g2s2g (26.12.2018).

KozŁowski Jan, „Teoria ewolucji: czy konflikt między nauką i wiarą jest nieunikniony?”, Nauka 2005, nr 3, s. 49-62, https://tiny.pl/tqfs5 (22.12.2018).

Krajna Andrzej, Ryk Leszek i Sujak-Lesz Krystyna (red.), Problemy dydaktyki fizyki, Oficyna Wydawnicza ATUT, Wrocław 2011.

Krause Tomasz, „Filozoficzne aspekty tzw. «afery Kansas»”, Filozoficzne Aspekty Genezy 2004, t. 1, s. 143-224, https://tiny.pl/g2863 (25.12.2018).

Kunn Thomas S., Przewrót kopernikański. Astronomia planetarna w dziejach myśli, przeł. Stefan Amsterdamski, PWN, Warszawa 1966.

Kunn Thomas S., Struktura rewolucji naukowych, przeł. Helena Ostromęcka, Justyna Nowotniak, Aletheia, Warszawa 2001.

LAKATOS Imre, „Falsyfikacja a metodologia naukowych programów badawczych”, w: LAKAтоs, Pisma z filozofii nauk empirycznych..., s. 3-169.

Lakatos Imre, Pisma z filozofii nauk empirycznych, przeł. Wojciech Sady, Biblioteka Współczesnych Filozofów, Wydawnictwo Naukowe PWN, Warszawa 1995.

Lamoureux Denis O., „Evolutionary Creation: Moving Beyond the Evolution versus Creation Debate", Christian Higher Education 2010, vol. 9, s. 28-48, https://tiny.pl/th3kl (12. 12.2018).

LARSON Ronald G., „O argumencie z Boga w lukach wiedzy raz jeszcze”, przeł. Joanna Popek, Filozoficzne Aspekty Genezy 2012, t. 9, s. 199-220, https://tiny.pl/xhzg7 (20.12.2018).

ŁAsTOwski Krzysztof, „Kilka uwag o sporze ewolucjonizmu z «naukowym kreacjonizmem» w związku z książką K. Jodkowskiego Metodologiczne aspekty kontrowersji ewolucjo- 
nizm-kreacjonizm", Przeglad Filozoficzny - Nowa Seria 2001, nr 1 (37), s. 229-240, https://tiny.pl/tq92v (21.12.2018).

Latawiec Anna i Bugajak Grzegorz (red.), Filozoficzne i naukowo-przyrodnicze elementy obrazu świata 7, Wydawnictwo Uniwersytetu Kardynała Stefana Wyszyńskiego, Warszawa 2008.

LemańsKa Anna, „Ewolucja jako realizacja projektu?”, Filozofia i Nauka 2015, t. 3, s. 353358, https://tiny.pl/tqw4j (22.12.2018).

Leszczyśski Damian (red.), Ewolucja. Filozofia. Religia, Lectiones \& Acroases Philosophicae 2010, vol. 3.

Lightman Alan P., „Przypadkowy Wszechświat: kryzys wiary w nauce”, przeł. Dariusz Sagan, Filozoficzne Aspekty Genezy 2012, t. 9, s. 255-267, https://iny.pl/xh8jq (27.12.2018).

LLoyd Steven, „«God of the Gaps»: A Valid Objection?”, Origins 2005, vol. 42, s. 7-10, https://tiny.pl/gzlgr (27.12.2018).

LuKIERSKI Jerzy, „Nauka i religia — czy można pogodzić?”, s. 1-5, https://tiny.pl/gzpd2 (27. 12.2018).

Luskin Casey, „Paper Reports That Amino Acids Used by Life Are Finely Tuned to Explore «Chemistry Space»", Evolution News \& Science Today 5 June 2015, https://tiny.pl/tq dz5 (26.12.2018).

Luskin Casey, „Teoria inteligentnego projektu nie wypowiada religijnych twierdzeń o sferze nadnaturalnej”, przeł. Izabela Janus, Filozoficzne Aspekty Genezy 2009/2010, t. 6/7, s. 93-116, https://tiny.pl/xhnlg (22.12.2018).

Łүко Zachariasz, Zarys filozofii chrześcijańskiej, Chrześcijańska Akademia Teologiczna, Warszawa 1995.

Mасек Wiesław M., Teologia nauki według księdza Michała Hellera, Wydawnictwo Uniwersytetu Kardynała Stefana Wyszyńskiego, Warszawa 2010.

Malec Grzegorz, „Charles Darwin and Lady Hope - The Legend Still Alive”, Hybris 2015, nr 29, s. 126-149, https://tiny.pl/tqf46 (27.12.2018).

MALEC Grzegorz, „Erozja teizmu Darwina, czyli wpływ podróży na okręcie HMS Beagle na poglądy teologiczne angielskiego przyrodnika”, w: BALĘKOWSKI i MACIĄG (red.), Wybrane zagadnienia..., s. 110-120, https://tiny.pl/g7krx (27.12.2018).

Malec Grzegorz, „Kiedy Darwin stracił wiarę w Boga?”, Diametros 2016, nr 48, s. 38-54, https://tiny.pl/tqf45 (27.12.2018).

MALEC Grzegorz, „Naturalizm metodologiczny w sporze ewolucjonizmu z kreacjonizmem w świetle poglądów Paula K. Feyerabenda", Filozoficzne Aspekty Genezy 2012, t. 9, s. 131154, https://tiny.pl/xhzfm (21.12.2018). 
MaLec Grzegorz, „Teologiczne dylematy Karola Darwina”, Roczniki Filozoficzne 2012, t. 60, nr 1, s. 67-85, https://tiny.pl/xhnkp (26.12.2018).

MARCiNIEC Jacek, „Piękno Wszechświata. Harmonia nauki i wiary w twórczości arcybiskupa Józefa Życińskiego", w: Wszołek (red.), Astronomia..., s. 133-144.

McMuluin Ernan, Ewolucja i stworzenie, przeł. Jacek Rodzeń, Ośrodek Badań Interdyscyplinarnych przy Wydziale Filozofii Papieskiej Akademii Teologicznej, Kraków 1990.

McMuluin Ernan, „Odmiany naturalizmu metodologicznego”, przel. Ewelina Topolska, Filozoficzne Aspekty Genezy 2012, t. 9, s. 109-129, https://tiny.pl/xh8pf (27.12.2018).

MeYer Stephen C., „Demarkacja nauki i religii”, przeł. Joanna Popek, Filozoficzne Aspekty Genezy 2009/2010, t. 6/7, s. 177-196, https://tiny.pl/xh8jj (26.12.2018).

MeYer Stephen C., Signature in the Cell: DNA and the Evidence for Intelligent Design, Harper One, New York 2009.

MeYer Stephen C., „The Use and Abuse of Philosophy of Science: A Response to Moreland", Perspectives on Science and Christian Faith 1994, vol. 46, no. 1, s. 19-21, https://ti ny.pl/h2wcm (25.12.2018).

Michalczenia Jakub, MiziśsKa Jadwiga i OssowsKa Katarzyna (red.), Poszukiwania filozoficzne. Tom I: Nauka, Prawda. Panu Profesorowi Józefowi Dębowskiemu w darze, Instytut Filozofii Uniwersytetu Warmińsko-Mazurskiego w Olsztynie, Olsztyn 2014.

MilLer Keith B., „Countering Public Misconceptions about the Nature of Evolutionary Science", Georgia Journal of Science 2005, vol. 63, no. 3, s. 175-189, https://tiny.pl/tqw12 (21.12.2018).

Milder Keith B., „The Misguided Attack on Methodological Naturalism”, w: SChNeIDERMAN and Allmon (eds.), For the Rock Record..., s. 117-140.

MilLeR Kenneth R., „Darwin, projekt i wiara katolicka”, przeł. Adam Grzybek, Filozoficzne Aspekty Genezy 2005/2006, t. 2/3, s. 35-38, https://tiny.pl/g2vmn (25.12.2018).

Minarowski Łukasz, „Nie wszystko trzeba wiedzieć (wywiad z Jamesem Deweyem Watsonem)", Medyk Biatostocki 2008, nr 67-68, s. 5-8, https://tiny.pl/g26v5 (24.12.2018).

МокRZҮскі Edmund (red.), Racjonalność a styl myślenia, Wydawnictwo IFiS PAN, Warszawa 1992.

Monton Bradley, Seeking God in Science: An Atheist Defends Intelligent Design, Broadview Press Inc., Toronto 2009.

Moreland James Porter and Craig William Lane, Philosophical Foundations for a Christian Worldview, InterVarsity Press, Downers Grove 2003.

Morris John D., „Jak powstało życie?”, przeł. Mieczysław Pajewski, Serwis Internetowy Polskiego Towarzystwa Kreacjonistycznego, https://tiny.pl/tqdnp (25.12.2018). 
NAGel Thomas, „Public Education and Intelligent Design”, Philosophy \& Public Affairs 2008, vol. 36, no. 2, s. 187-205.

Niтeскі Matthew H. (ed.), Evolutionary Progress, University of Chicago Press, Chicago 1988.

Ośrodek Badania Opinii Publicznej, „Ewolucja po polsku”, TNS OBOP sondaż z 36.11.2006, s. 1-16, https://tiny.pl/tqfvj (22.12.2018).

Pabian Tadeusz, „Nauka i wiara — razem czy osobno?”, Nauka i Religia.PL 29 lipca 2015, https://tiny.pl/tqdk5 (26.12.2018).

Pajewski Mieczysław, „Papież Benedykt XVI potwierdza kapitulancką postawę kościoła katolickiego wobec ateistycznie zorientowanych uczonych", Idź Pod Prąd 2008, nr 11 (52), s. 10, https://tiny.pl/tqmb7 (15.12.2018).

Pearcey Nancy, „Ewolucjonizm po Darwinie”, przeł. Kazimierz Jodkowski, w: Jodкоwsкi, Metodologiczne aspekty..., s. 431-446, https://tiny.pl/tq92z (21.12.2018).

PeArCey Nancy, „Wpływ ewolucjonizmu na filozofię i etykę”, przeł. Kazimierz Jodkowski, w: Joркошккі, Metodologiczne aspekty..., s. 447-459, https://tiny.pl/gt5w6 (22.12.2018).

Pennock Robert T., „Creationism and Intelligent Design”, Annual Review of Genomics and Human Genetics 2003, vol. 4, s. 143-163, https://tiny.pl/tqdz7 (26.12.2018).

PietrZak Zbigniew (red.), Granice nauki, Lectiones \& Acroases Philosophicae 2013, vol. $6, \mathrm{nr} 1$.

PIGLIUCCI Massimo, „Science and Fundamentalism”, EMBO Reports 2005, vol. 6, no. 12, s. 1106-1109, https://tiny.pl/g2vmw (26.12.2018).

Plantinga Alvin, „Naturalizm metodologiczny?”, przeł. Radosław Plato, Filozoficzne Aspekty Genezy 2014, t. 11, s. 37-93, https://tiny.pl/xh89b (21.12.2018).

Polkinghorne John C., Nauka i stworzenie. Poszukiwanie zrozumienia, przeł. Marek Chojnacki, Wydawnictwo Apostolstwa Modlitwy, Kraków 2008.

PoMORSкI Jan (red.), Wartość relatywizmu jako postawy poznawczej, Realizm. Racjonalność. Relatywizm, t. 11, Wydawnictwo UMCS, Lublin 1989.

Preston John, Feyerabend: Philosophy, Science and Society, Polity Press, Cambridge UK, Blackwell, Malden, Massachusetts 1997.

Provine William B., „Evolution: Free Will and Punishment and Meaning in Life”, Second Annual Darwin Day Celebration, University of Tennessee, Knoxville, Feb. 12, 1998, http:// tiny.pl/q6xp8 (28.12.2018).

Provine William B., „Progress in Evolution and Meaning of Life”, w: Nitecki (ed.), Evolutionary Progress..., s. 49-74. 
Quammen David, „Czy Darwin się mylił?”, National Geographic Polska 2004, nr 11 (62), s. 2-33.

Reeves Josh A. and Donaldson Steve, A Little Book for New Scientists: Why and How to Study Science, InterVarsity Press, Downers Grove, Illinois 2016.

ReNNIE John, „15 odpowiedzi na nonsensowne tezy kreacjonistów”, przeł. Karol Sabath, Świat Nauki 2002, nr 9, s. 66-72, https://tiny.pl/gzpws (22.12.2018).

RoткIEwIcz Marcin, „Barbarzyńcy u bram”, Polityka 26 stycznia 2008, nr 4 (2638), s. 92, https://tiny.pl/g8zfm (26.12.2018).

RowiŃskı Tomasz, „Dlaczego warto nauczać «dwóch stron»? O edukacji, ewolucji i teorii inteligentnego projektu. Rozmowa z o. Michałem Chaberkiem, dominikaninem, doktorem teologii fundamentalnej, autorem książki Stworzenie czy ewolucja? Dylemat katolika", Christianitas 2014, nr 58, s. 70-82, https://tiny.pl/g2szj (27.12.2018).

Rоżко Karolina, „Teologia naturalna Stokesa”, Filozoficzne Aspekty Genezy 2009/2010, t. 6/7, s. 213-226, https://tiny.pl/tqfng (27.12.2018).

Ruse Michael, Darwinism Defended: A Guide to the Evolution Controversies, AddisonWesley, Reading, Massachusetts 1982.

Ruse Michael, „Darwinizm a problem zła”, przeł. Aleksandra Bulaczek, Filozoficzne Aspekty Genezy 2011, t. 8, s. 23-38, https://tiny.pl/tqwpz (22.12.2018).

RuSE Michael, „How Evolution Became a Religion: Creationists Correct?: Darwinians Wrongly Mix Science with Morality, Politics”, National Post 13 May 2000, https://tiny.pl/ g4rxp (28.12.2018).

Russell Colin A., Cross-Currents: Interactions Between Science and Faith, InterVarsity Press 1985.

RyLAND Mark, „«Teoria inteligentnego projektu» podważa teorię ewolucji. Już sama złożoność stworzenia świadczy o działaniu siły wyższej. Darwinizm? Nie ma szans. Wywiad z Michaelem J. Behe'em dla Our Sunday Visitor', przeł. Dariusz Sagan, Na Poczatku... 2004, nr 11-12A (187-188), s. 414-420, https://tiny.pl/g2vmb (22.12.2018).

SABAтH Karol, „Kreacjonizm a sprawa polska”, Świat Nauki 2002, nr 9, s. 73, https://tiny.pl /gzpws (22.12.2018).

SADY Wojciech, „Czego Kazimierz Jodkowski nie dostrzega, jeśli o odkrycia naukowe chodzi?", w: Bylica, Kilian, Piotrowski i Sagan (red.), Filozofia — nauka — religia..., s. 5964, https://tiny.pl/g268h (22.12.2018).

SADY Wojciech, „Dlaczego kreacjonizm «naukowy» nie jest naukowy i dlaczego nie prowadzi do teizmu?", Przeglad Filozoficzny - Nowa Seria 2001, nr 1 (37), s. 213-228, https: //tiny.pl/gdw91 (23.12.2018). 
SAGAN Dariusz, „Argument z niedoskonałości i zła w kontekście sporu o ewolucję i inteligentny projekt", Logos i Ethos 2013, nr 1 (34), s. 129-148, https://tiny.pl/q336m (23.12. 2018).

Sagan Dariusz, „Debata Benedykta XVI i jego uczniów nad stworzeniem i ewolucją”, Filozoficzne Aspekty Genezy 2005/2006, t. 2/3, s. 7-17, https://tiny.pl/xhnqr (23.12.2018).

SAGAN Dariusz, „Ewaluacja ewolucjonistycznych rozwiązań problemu nieredukowalnej złożoności”, Otwarte Referarium Filozoficzne 2009, t. 2, s. 89-116, https://tiny.pl/q3mjg (21.12.2018).

SAGAN Dariusz, „Kardynał Schönborn a stanowisko Kościoła katolickiego wobec sporu kreacjonizmu z ewolucjonizmem", Filozofia Nauki 2006, nr 1 (53), s. 107-118, https://tiny. $\mathrm{pl} / \mathrm{g} 2 \mathrm{vg} 9$ (25.12.2018).

SAGAN Dariusz, „Kazimierz Jodkowski o teorii inteligentnego projektu”, w: ByLICA, Kilian, Piotrowski i SAGAN (red.), Filozofia - nauka - religia..., s. 213-227, https://tiny.pl/tqdkr (25.12.2018).

SAgan Dariusz, „Kościół a ewolucyjny materializm. George Sim Johnston: Czy Darwin miał rację? Katolicka teoria ewolucji, przeł. Joanna Kaliszczyk, Kraków, Wydawnictwo WAM, 2005”, Edukacja Filozoficzna 2005, vol. 40, s. 223-228, https://tiny.pl/xhnmj (28. 12.2018).

SAGAN Dariusz, Metodologiczno-filozoficzne aspekty teorii inteligentnego projektu, $B i$ blioteka Filozoficznych Aspektów Genezy, t. 6, Instytut Filozofii Uniwersytetu Zielonogórskiego, Zielona Góra 2015, https://tiny.pl/g7m72 (22.12.2018).

SAGan Dariusz, „Molekularny «zegar Paleya» a darwinowska ewolucja”, Ruch Filozoficzny 2005, t. 42, nr 2, s. 289-304, https://tiny.pl/xh8tk (21.12.2018).

SAGAN Dariusz, „Naturalizm metodologiczny — konieczny warunek naukowości?”, Roczniki Filozoficzne 2013, t. 61, nr 1, s. 73-91, https://tiny.pl/q33sb (25.12.2018).

SAGAN Dariusz, „O programie badawczym teorii inteligentnego projektu”, Filozoficzne Aspekty Genezy 2013, t. 10, s. 73-108, https://tiny.pl/q3369 (28.12.2018).

SAGAN Dariusz, „Odpowiedź na uwagi polemiczne ks. dra Marka Słomki do mojego artykułu o filtrze eksplanacyjnym", Roczniki Filozoficzne 2009, t. 57, nr 1, s. 345-349, https://ti ny.pl/xhzm6 (25.12.2018).

SAGAN Dariusz, ,Problem religijnego charakteru teorii inteligentnego projektu”, Studia Philosophica Wratislaviensia 2011, vol. 6, fasc. 4, s. 55-74, https://tiny.pl/q336q (22.12.2018).

SAGAN Dariusz, „Retoryczna historia Ruchu Inteligentnego Projektu”, Diametros 2005, nr 4, s. 76-85, https://tiny.pl/xhh8f (21.12.2018).

SAGAN Dariusz, „Spór o możliwość wykrywania projektu w naukach przyrodniczych”, Scientia et Fides 2015, vol. 3, nr 1, s. 87-113, https://tiny.pl/gz16f (23.12.2018). 
SAGAN Dariusz, Spór o nieredukowalną złożoność układów biochemicznych, Biblioteka Filozoficznych Aspektów Genezy, t. 5, Wydawnictwo MEGAS, Warszawa 2008, https://ti ny.pl/qzq8p (22.12.2018)

SAGAn Dariusz, „Spór o użyteczność teorii inteligentnego projektu dla nauki”, Kultura i Edukacja 2013, nr 3 (96), s. 28-49, https://tiny.pl/xhhg3 (22.12.2018).

SAGAN Dariusz, „Teoria inteligentnego projektu a ewolucjonizm”, Kwartalnik Filozoficzny 2013, t. 41, z. 2, s. 75-96, https://tiny.pl/q336x (21.12.2018).

SAGAN Dariusz, „Teoria inteligentnego projektu a kreacjonizm”, Kwartalnik Filozoficzny 2015, t. 43, z. 2, s. 131-150, https://tiny.pl/g2vmx (25.12.2018).

SAGAN Dariusz, „Teoria inteligentnego projektu a naukowa debata nad pochodzeniem”, w: JODKOWSKI (red.), Teoria inteligentnego projektu..., s. 79-122, https://tiny.pl/qzq8f (25. 12.2018).

SAGAN Dariusz, „Teoria inteligentnego projektu - argumenty za i przeciw”, w: JANECZEK, Starościc, DąbeK i Herda (red.), Filozofia przyrody..., s. 335-383, https://tiny.pl/q336w (22.12.2018).

Sagan Dariusz, „The Nature of Design Inference and the Epistemic Status of Intelligent Design”, International Philosophical Quarterly 2019, vol. 59, no. 1, s. 37-55.

SAGAn Dariusz, „Wnioskowanie do najlepszego wyjaśnienia jako metodologiczna podstawa teorii inteligentnego projektu", Zagadnienia Naukoznawstwa 2014, nr 1 (199), s. 41-59, https://tiny.pl/tqdzx (26.12.2018).

SAGAn Dariusz, „Wnioskowanie o projekcie a warunek niezależnej wiedzy o projektancie”, Przeglad Filozoficzny - Nowa Seria 2014, nr 2 (90), s. 153-171, https://tiny.pl/tq9r4 (29. 12.2018).

SAGAN Dariusz, „Wspólnota pochodzenia jako argument w sporze darwinizm-teoria inteligentnego projektu", Diametros 2013, nr 37, s. 127-145, https://tiny.pl/q336h (21.12.2018).

SAGAN Dariusz, „Wyjaśnianie za pomocą praw przyrody jako warunek naukowości w sporze o ewolucję i inteligentny projekt", Studia Philosophiae Christianae 2013, t. 49, nr 1, s. 93-116, https://tiny.pl/q336g (23.12.2018).

SAGAN Dariusz, „Zarzut nietestowalności teorii inteligentnego projektu”, Studia Philosophica Wratislaviensia 2013, vol. 8, fasc. 3, s. 43-59, https://tiny.pl/q33s3 (23.12.2018).

SAGAN Dariusz, „Zdolność przewidywania jako warunek naukowości w sporze o ewolucję i inteligentny projekt”, Zagadnienia Naukoznawstwa 2012, nr 4 (194), s. 269-286, https://ti ny.pl/q3367 (26.12.2018).

Schneiderman Jill S. and Allmon Warren D. (eds.), For the Rock Record: Geologists on Intelligent Design, University of California Press, Berkeley, Los Angeles, London 2009. 
SchönBorn Christoph, „Odnajdywanie zamysłu w przyrodzie”, przeł. Piotr Lenartowicz SJ, Filozoficzne Aspekty Genezy 2005/2006, t. 2/3, s. 19-22, https://tiny.pl/xhhdk (25.12.2018).

Scotт Eugenie C., Evolution vs. Creationism: An Introduction, 2nd ed., Greenwood Press, Westport, Connecticut, London 2009.

Scotт Eugenie and Cole Henry, „The Elusive Scientific Basis of Creation «Science»”, The Quarterly Review of Biology 1985, vol. 60, s. 21-30, https://tiny.pl/tqdzw (23.12.2018).

Siemieniewski Andrzej, „Między cudownością a cudem”, Teologia Duchowości 22 grudnia 2018, https://tiny.pl/tqfvm (27.12.2018).

SIMPSON George Gaylord, The Meaning of Evolution: A Study of the History of Life and of Its Significance for Man, rev. ed., The Terry Lectures Series, Yale University Press, New Haven 1976.

SŁomKa Marek (red.), Nauki przyrodnicze a nowy ateizm, Filozofia Przyrody i Nauk Przyrodniczych, t. 8, Wydawnictwo KUL, Lublin 2012.

SŁomKa Marek, „Powrót inteligentnego projektanta. Uwagi polemiczne do artykułu Dariusza Sagana «Filtr eksplanacyjny: wykrywanie inteligentnego projektu na gruncie nauk przyrodniczych»", Roczniki Filozoficzne 2009, t. 57, nr 1, s. 341-345, https://tiny.pl/tqdkx (25.12.2018).

SŁowik Grzegorz P. i Kilian Krzysztof J., „Hoyle i matematyczne dylematy ewolucjonizmu", w: Bylica, Kilian, Piotrowski i Sagan (red.), Filozofia - nauka - religia..., s. 395-408, https://tiny.pl/tqw1v (22.12.2018).

SNOKE David W., „Biologia systemowa jako paradygmat badawczy teorii inteligentnego projektu", przeł. Dariusz Sagan, Filozoficzne Aspekty Genezy 2015, t. 12, s. 255-285, https://tiny.pl/tqdn6 (25.12.2018).

SNoKe David W., „Jak w zaprojektowanym Wszechświecie zdefiniować to, co niezaprojektowane", przeł. Dariusz Sagan, Filozoficzne Aspekty Genezy 2009/2010, t. 6/7, s. 117-137, https://tiny.pl/xhnms (22.12.2018).

SoBer Elliott, „Teoria inteligentnego projektu a nadnaturalizm — o tezie, że projektantem może być Bóg lub istoty pozaziemskie", przeł. Sławomir Piechaczek, Filozoficzne Aspekty Genezy 2007/2008, t. 6/7, s. 21-39, https://tiny.pl/xhn85 (21.12.2018).

Sobór Watykański I, Konstytucja dogmatyczna o wierze katolickiej.

Statham Dominic, „Darwin's Corrosive Idea”, Creation Ministries International 19 September 2017, https://tiny.pl/tqd3d (26.12.2018).

Stawiszyński Tomasz, „Bóg jest zbędny”, Newsweek Polska 13 września 2010, https://tiny. $\mathrm{pl} / \mathrm{g} 26 \mathrm{vx}(22.12 .2018)$. 
SuPPE Frederick, „The Search for Philosophic Understanding of Scientific Theories”, w: Suppe (ed.), The Structure of Scientific Theories..., s. 1-241.

Suppe Frederick (ed.), The Structure of Scientific Theories, University of Illinois Press, Urbana — Chicago — London 1977.

Tнахтол Charles, „Nowy argument z projektu”, przeł. Izabela Janus, Filozoficzne Aspekty Genezy 2011, t. 8, s. 155-177, https://tiny.pl/xhn2p (22.12.2018).

THORNHILl Richard, „Historyczny związek między darwinizmem a argumentem z biologicznego projektu", przeł. Anna Droś, Natalia Górska, Mateusz Krzyżanowski, Renata Merda, Zofia Sadowska i Dariusz Sagan, Filozoficzne Aspekty Genezy 2012, t. 9, s. 79-105, https:// tiny.pl/gzlnb (23.12.2018).

Twardowski Mirosław, „Wiara w stworzenie a teoria ewolucji: konflikt czy symbioza? Debata «Schülerkreis» Josepha Ratzingera nad relacją stworzenie-ewolucja", Tarnowskie Studia Teologiczne 2013, t. 32, nr 1, s. 33-46, https://tiny.pl/g26vr (23.12.2018).

VAN DER MeER Jitse M., „Pojęcie natury ludzkiej w nauce i teologii”, przeł. Radosław Plato, Filozoficzne Aspekty Genezy 2013, t. 10, s. 243-250, https://tiny.pl/tqf8h (27.12.2018).

VAN DER MeER Jitse M., „Przekonania towarzyszące, ideologia i nauka”, przeł. Dariusz Sagan, Filozoficzne Aspekty Genezy 2016, t. 13, s. 153-194, https://tiny.pl/gzjrs (27.12.2018).

VRIEs Paul DE, „Naturalizm w naukach przyrodniczych. Perspektywa chrześcijańska”, przeł. Radosław Plato, Filozoficzne Aspekty Genezy 2011, t. 8, s. 121-135, https://tiny.pl/xh8gc (27.12.2018).

WARzyc Michał, „Dar, który wciąż jest wyzwaniem”, Semina Scientiarum 2009, nr 8, s. 129-133, https://tiny.pl/tq591 (27.12.2018).

WASZKIEWICZ Jan, „O świętości, harmonii Wszechświata i rewolucji naukowej, czyli o miejscu matematyki w kulturze", Matematyka - Społeczeństwo - Nauczanie 1993, nr 11, s. 2 10, https://tiny.pl/tq59b (27.12.2018).

West John G., „Darwin's Corrosive Idea: The Impact of Evolution on Attitudes About Faith, Ethics, and Human Uniqueness", Discovery Institute's Center for Science and Culture 2016, s. 1-19, https://tiny.pl/tqd3r (26.12.2018).

West John G., „Teoria inteligentnego projektu jest wyjątkowo źle rozumiana”, przeł. Dariusz Sagan, $\mathrm{Na}$ Poczatku... 2005, nr 11-12A (200-201), s. 458-460, https://tiny.pl/xh4zj (23.12.2018).

Wielgus Stanisław W. (w imieniu Rady Naukowej Konferencji Episkopatu Polski), „Kościół wobec ewolucji. Stanowisko Rady Naukowej Konferencji Episkopatu Polski. 27.11. 2006", Opoka.org.pl, https://tiny.pl/tqfk8 (27.12.2018).

Wilson Edward O., O naturze ludzkiej, przeł. Barbara Szacka, Biblioteka Myśli Współczesnej, Państwowy Instytut Wydawniczy, Warszawa 1988. 
Wiśniewski Andrzej, „Dlaczego należy czytać Jodkowskiego?”, w: BylicA, Kilian, PiotrowSKI i SAGAN (red.), Filozofia - nauka - religia..., s. 37-41, https://tiny.pl/g268h (23.12. 2018).

WITT Jonathan, „Zarys historii powstania naukowej teorii inteligentnego projektu”, przeł. Dariusz Sagan, Na Poczatku... 2005, nr 9-10 (198-199), s. 352-362, https://tiny.pl/xhh8q (22.12.2018).

Wojnar Anna, „Czy nauka zastąpi religię?”, Alma Mater. Miesięcznik Uniwersytetu Jagiellońskiego 2008, nr 108, s. 91-94, https://tiny.pl/g26sl (22.12.2018).

WOODWARD Thomas, „Istota sporu darwinizmu z teorią inteligentnego projektu: przyrodnicza symfonia makroewolucji”, przeł. Dariusz Sagan, Filozoficzne Aspekty Genezy 2007/ 2008 , t. 6/7, s. 7-20, https://tiny.pl/xhnkv (25.12.2018).

Wszotek Bogdan (red.), Astronomia - nauka i wiara. Tom II. Pamięci księdza Bonawentury Metlera, Stowarzyszenie Astronomia Nova oraz Instytut Fizyki Akademii im. Jana Długosza w Częstochowie, Częstochowa 2015.

Wszołek Stanisław, „W obronie argumentu «God of the gaps»”, Zagadnienia Filozoficzne w Nauce 1999, t. 23, s. 103-118, https://tiny.pl/tqfsz (27.12.2018).

YAHYa Harun, Design in Nature, Ta-Ha Publishers Ltd., London 2004, https://tiny.pl/tqjg6 (25.12.2018).

ZавоєотNY Andrzej, „Naturalizm metodologiczny w nauce - dylemat teisty”, Filozoficzne Aspekty Genezy 2016, t. 13, s. 25-48, https://tiny.pl/gzp1f (27.12.2018).

Zachariasz Andrzej L., Filozofia. Jej istota i funkcje, Wydawnictwo UMCS, Lublin 1994.

Zachariasz Andrzej L., Poznanie teoretyczne. Jego konstytucja i status, Wydawnictwo UMCS, Lublin 1989.

Zachariasz Andrzej L. (red.), Profile racjonalności, Wydawnictwo UMCS, Lublin 1988.

ZalewsKa Ewa, „Johna F. Haughta poglądy na temat relacji nauka-religia”, Filozoficzne Aspekty Genezy 2007/2008, t. 6/7, s. 127-160, https://tiny.pl/tqwjk (29.12.2018).

ZoN Józef, „Nic nowego w starym sporze”, Filozoficzne Aspekty Genezy 2005/2006, t. 2/3, s. 25-33, https://tiny.pl/xhkgf (21.12.2018).

ŻyCIŃSKI Józef, Bóg i ewolucja. Podstawowe pytania ewolucjonizmu chrześcijańskiego, Prace Wydziału Filozoficznego, t. 89, Towarzystwo Naukowe KUL, Lublin 2002.

Życińsk Józef, „Ewolucyjna wizja przyrody a XIX-wieczny teizm”, Studia Philosophiae Christianae 1996, t. 32, nr 1, s. 73-89, https://tiny.pl/ttfl2 (27.12.2018).

ŻyciŃsk Józef, „Naturalizm ontologiczny a rola superweniencji w ewolucji biologicznej”, Roczniki Filozoficzne 2003, t. 51, z. 3, s. 7-18, https://tiny.pl/tqfhz (26.12.2018). 
ŻyciŃsKi Józef, „U źródeł biologii niearystotelesowskiej”, w: Michał Heller i Józef ŻyCIŃSKI, Dylematy ewolucji, Polskie Towarzystwo Teologiczne, Kraków 1990, s. 9-39.

Życiński Józef i Hetmański Marek, „Religijny a naukowy obraz świata (debata)”, Annales Universitatis Mariae Curie-Skłodowska 2012, sec. I, vol. 37, nr 1, s. 53-76, https://tiny.pl/ tqfkl (27.12.2018).

\section{Światopoglądowy i ideologiczny wymiar epistemicznych układów odniesienia a teistyczno-naturalistyczny epistemiczny układ odniesienia}

\section{Streszczenie}

Artykuł ten wyjaśnia, na czym polega światopoglądowe i ideologiczne zaangażowanie EUO. Wskazuje też na światopoglądowe i ideologiczne składniki EUO. Pokazane też zostanie, że ideologiczno-światopoglądowy konflikt między odmiennymi EUO prowadzi do, zachodzącej już, zmiany oblicza zachodniej cywilizacji.

$\mathrm{Na}$ tym tle przedstawiony jest teizm naturalistyczny. Uprzednio omówione EUO tworzą poznawcze ramy dla uprawiania nauki. Zaś naturalistyczny teizm jest takim EUO, który tworzy również inną, specyficzną, światopoglądową ramę uprawiania nauki. Dzięki niej ma być możliwe zażegnanie kryzysu wiary wśród ludzi wykształconych, w szczególności naukowców. Kryzys ten jest następstwem niezgodności tradycyjnego teistycznego oraz współczesnego naukowego opisu świata.

Teizm naturalistyczny ma być też udaną próbą obrony cywilizacji chrześcijańskiej przed próbami przekształcenia jej w cywilizację postchrześcijańską. Obrona ta odbywać ma się drogą pogodzenia obrazu świata współczesnego przyrodoznawstwa z teizmem chrześcijańskim.

Zarówno zażegnanie kryzysu wiary, jak i godzenie obrazu świata przyrodoznawstwa z teistycznym obrazem świata odbywa się drogą , umiejętnego czytania” ksiąg Pisma Świętego. Zaś takie „czytanie” ma olbrzymie koszty światopoglądowe i epistemiczne.

Slowa kluczowe: epistemiczny układ odniesienia, teistyczno-naturalistyczny epistemiczny układ odniesienia, teizm naturalistyczny, naturalizm metodologiczny, ideologia, światopogląd.

\section{The Worldview and Ideological Dimension of Epistemic Frameworks Generally and the Theistic-Naturalistic Epistemic Framework in Particular}

\section{Summary}

This paper explains what it is for epistemic frameworks to involve worldviews and ideological commitments, while also indicating the actual worldviews and ideological components present in such frameworks. In addition, it sets out to show that the ideological conflict be- 
tween different epistemic frameworks is already bringing about changes to the form of Western civilization.

Against this general background, naturalistic theism is presented. The epistemic frameworks previously discussed give rise to cognitive frameworks for the practicing of science, and naturalistic theism is one such epistemic framework, furnishing a specific and distinctive worldview framework of its own for scientific practice. In this case, its aim is to enable an overcoming of the crisis of faith amongst educated people generally and scientists in particular. That crisis is a consequence of the incompatibility of a traditional theistic description of the world with the contemporary scientific one.

Naturalistic theism, moreover, seeks to defend Christian civilization from attempts to transform it into a post-Christian civilization. It aims to achieve this by reconciling the image of the world provided by contemporary natural science with Christian theism itself.

Both the defusing of the crisis of faith and the reconciling of the scientific and theistic images of the world are to be accomplished through a "skillful reading" of Biblical texts. However, where the accompanying worldview and epistemic commitments are concerned, such a "reading" comes at a very high price.

Keywords: epistemic framework, theistic-naturalistic epistemic framework, naturalistic theism, methodological naturalism, ideology, worldview. 